I

A Summary of Cooperative Water Resources Investigations

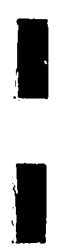

U.S. Geological Survey and

Wisconsin Department of Natural Resources
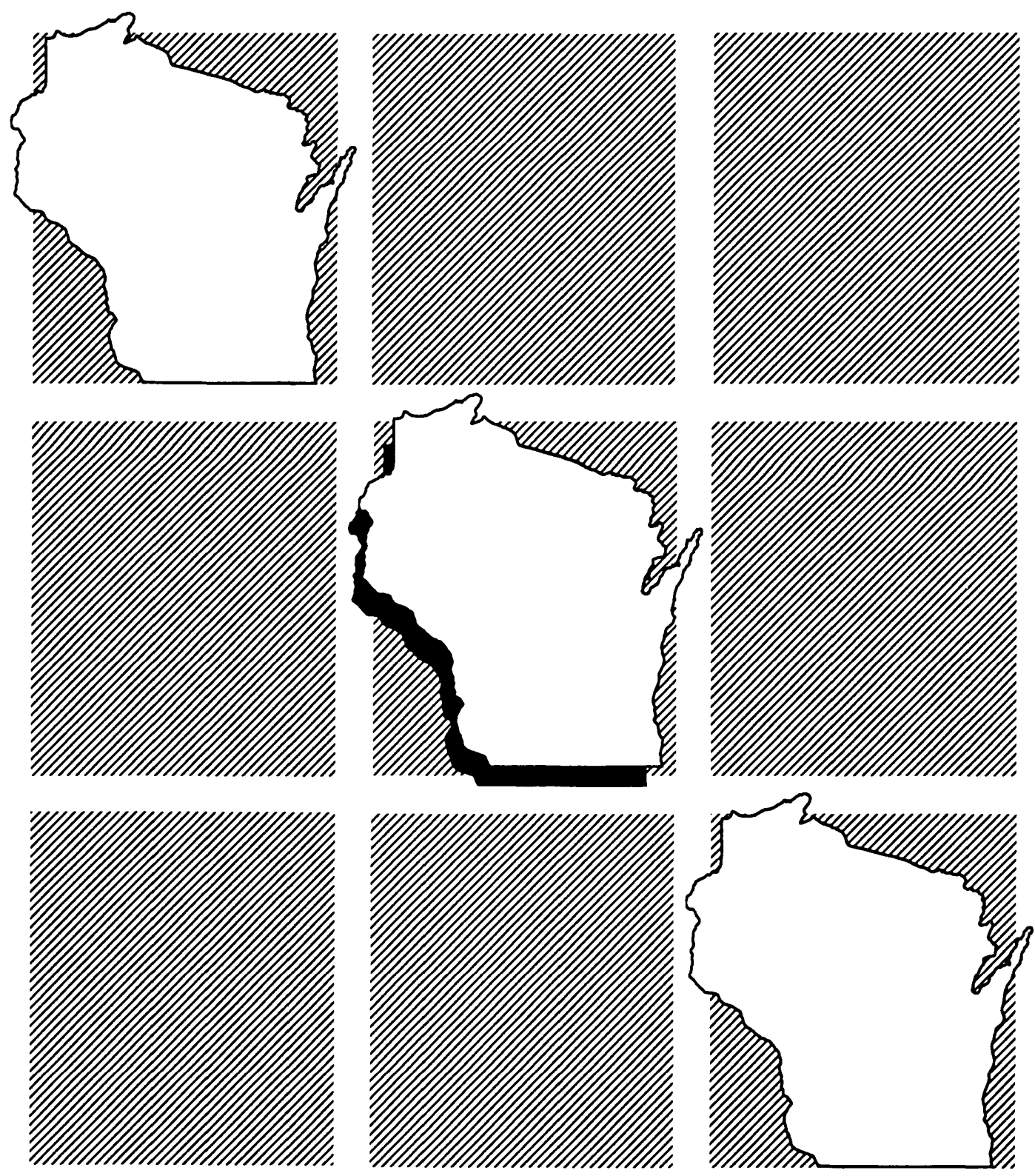

2000

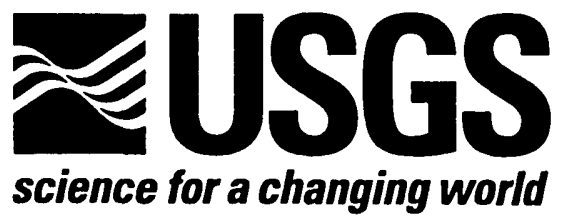


I

I

I

|

I

I

,

I

I

I

I

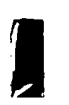

I 


\section{A SUMMARY OF COOPERATIVE WATER-RESOURCES INVESTIGATIONS}

\section{U.S. GEOLOGICAL SURVEY}

Water Resources Division

8505 Research Way

Middleton, Wisconsin 53562

and

WISCONSIN DEPARTMENT OF NATURAL RESOURCES

P.O. Box 7921

Madison, Wisconsin 53707 


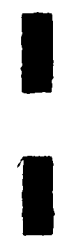

I

I

I

I

I

I

I

I

I

I

I

I

I

I

I

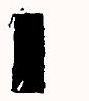

| 


\section{A Summary of Cooperative Water-Resources Investigations U.S. Geological Survey and Wisconsin Department of Natural Resources}

2000

The cooperative program of water-resources investigations between the U.S. Geological Survey and the Wisconsin Department of Natural Resources began as a continuation of cooperative programs with the various State agencies which were merged to form the Wisconsin Department of Natural Resources. These investigations involve various aspects of research, resource evaluations, and water-quantity- and waterquality-monitoring activities.

This is a brief summary report of the activities and plans for the cooperative projects during the July 1999 through June 2000 fiscal year. Each project summary includes a brief description of the objectives, approach, and progress during the 2000 fiscal year, and plans for the 2001 fiscal year.

The appendixes include a detailed listing of proposed stream-monitoring stations for 2001. Also included is the proposed funding summary for the 2000-2001 fiscal year.

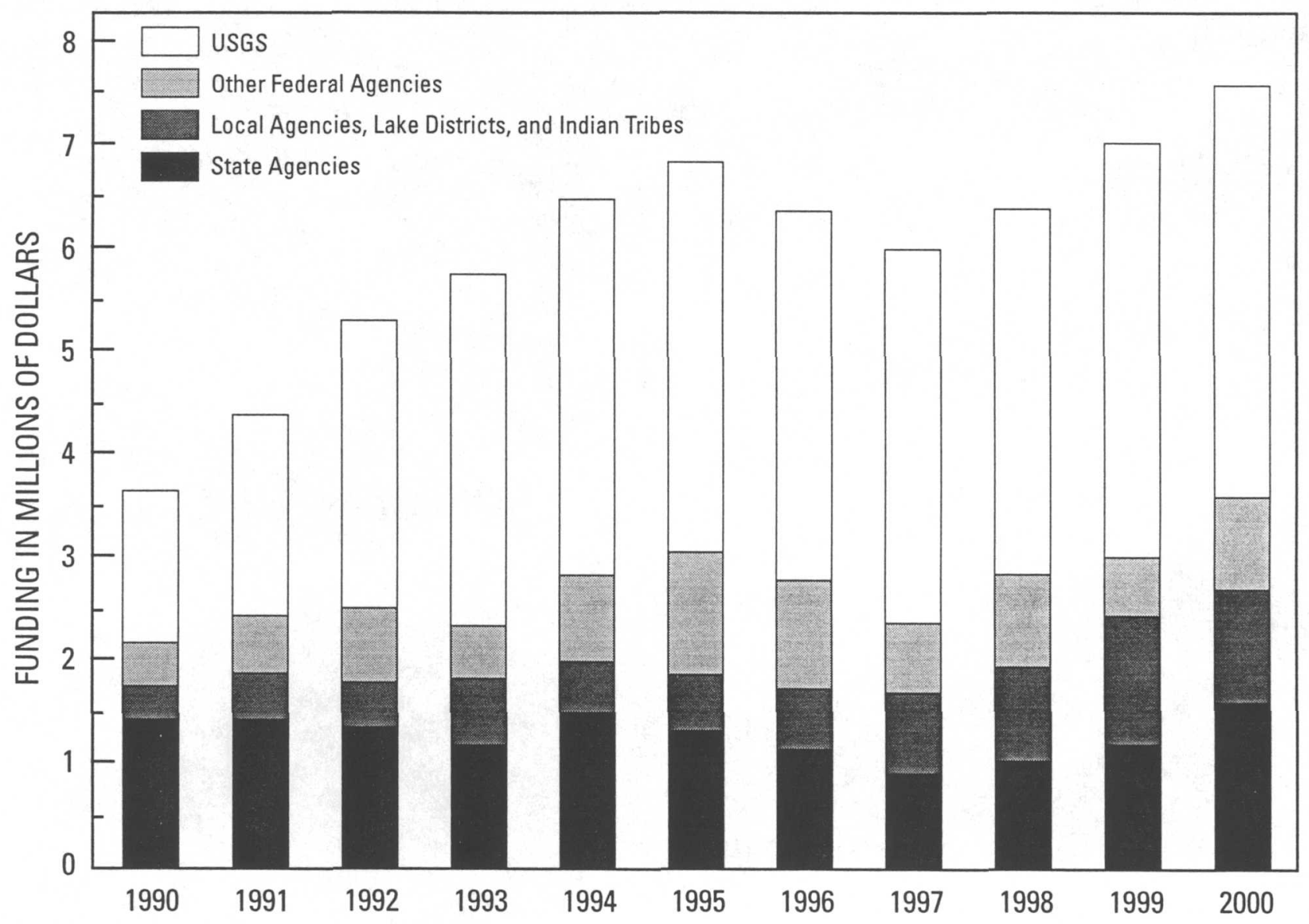


Funding sources for the Wisconsin District program for FY 2000 are shown on the following chart:

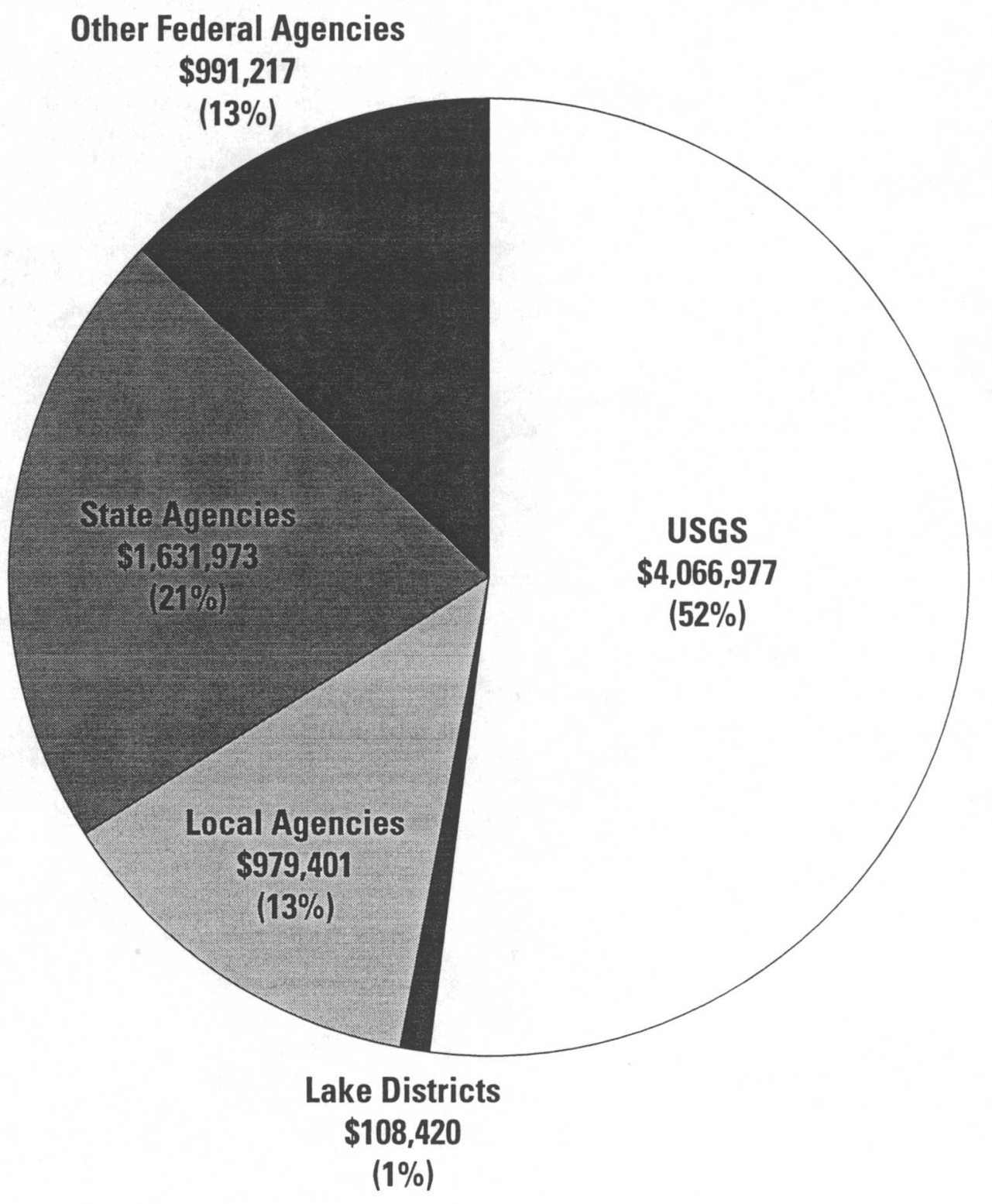

Total Funding $=\$ \mathbf{\$}, 777,988$ 


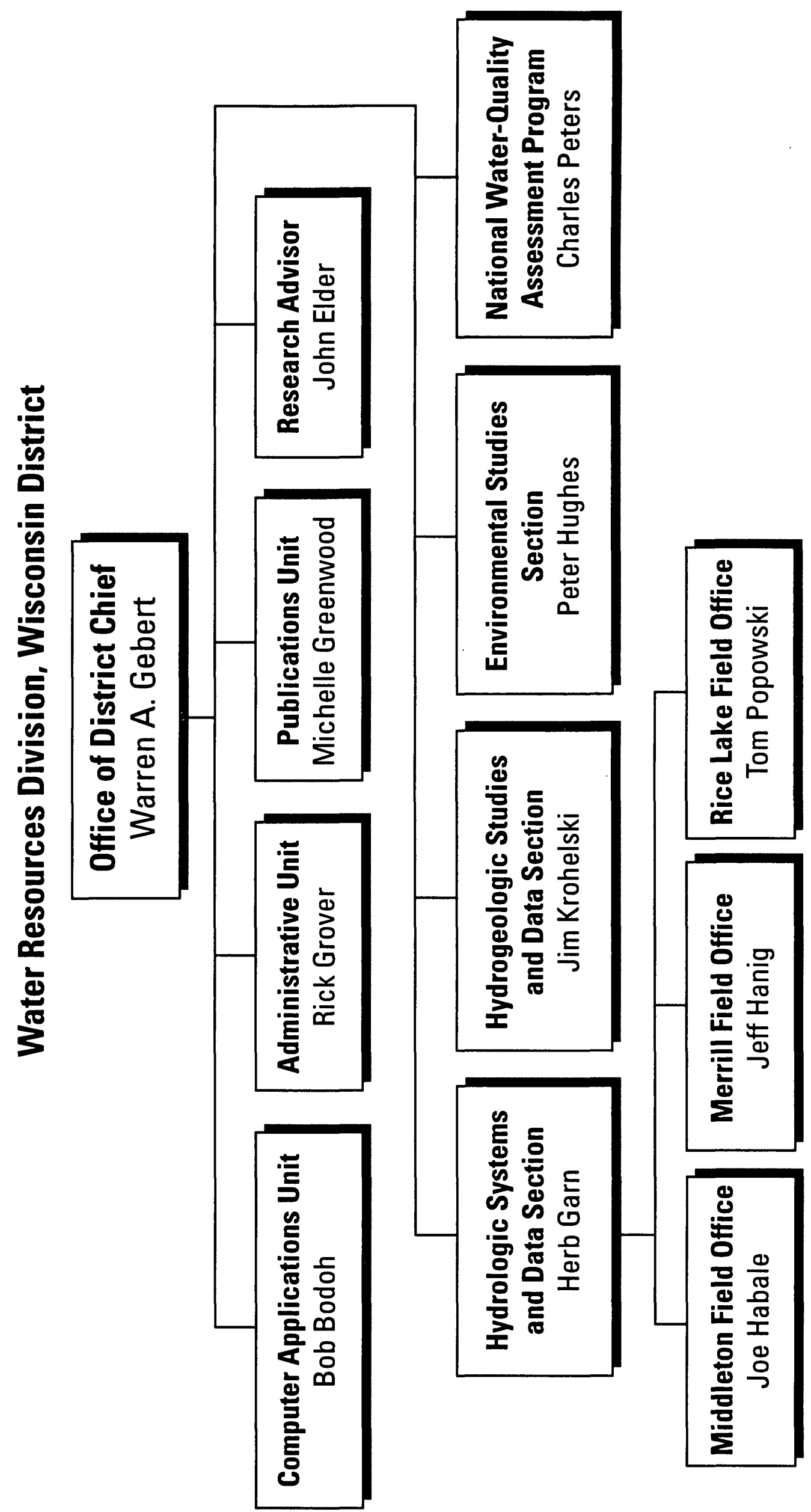


I

I

I

I

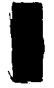

I

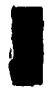

I

I

I

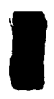

I

I

I

I

I

I

vi

I 


\section{CONTENTS}

Program

Basic data collection

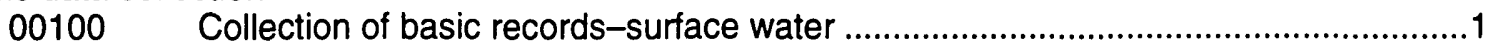

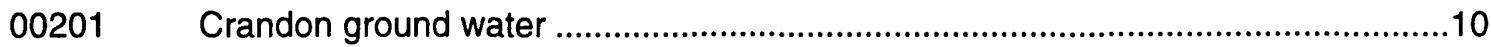

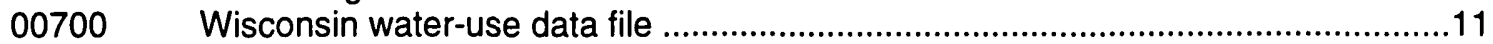

Interpretive studies

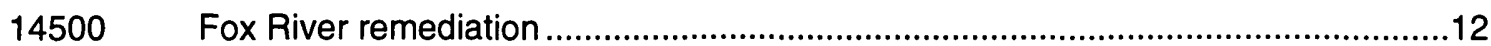

17202, 04 Trends in water quality and stream habitat for priority watersheds ........................14

17213

17206

17214

17223

17229

17233

17234

17236

18301

19101

Best management practice evaluation .............................................................16

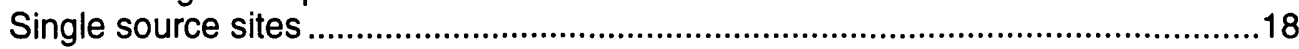

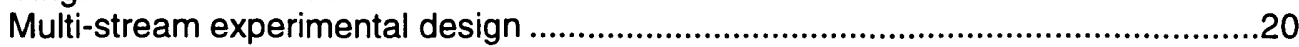

Hydrology and water quality of three pastures in southwestern Wisconsin .............21

Evaluation of the effectiveness of urban conservation design practices .................23

Temperature modeling of urban stormwater runoff ...............................................24

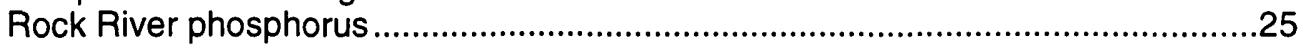

Trace metal loading to Lakes Michigan and Superior ..........................................26

Transport and biogeochemical cycling of PCBs in the Hayton Millpond,

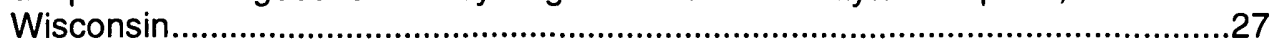

20200, 02 Mitigation of future north fork urbanization impacts on the Pheasant Branch

20203

21000 hydrologic system

21800

Database applications....

The effect of near-shore development on constituent loading to lakes in northern Wisconsin

Appendixes:

Appendix A:

00100 Stream-gaging stations proposed for fiscal year 2001 .33

Appendix B: Funding summary proposed for general cooperative program with Wisconsin Department of Natural Resources, fiscal year 2000

Wisconsin District publications

Wisconsin District personnel 
I

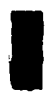

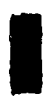

I

,

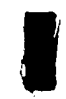

I

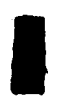

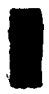

I

,

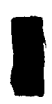




\section{COLLECTION OF BASIC RECORDS-SURFACE WATER, WI 00100}

\section{COOPERATORS:}

Bad River Band of Lake Superior Chippewa Indians

City of Barron

City of Beaver Dam

City of Black River Falls

City of Brookfield

City of Fort Atkinson

City of Hillsboro

City of Peshtigo

City of Sparta

City of Thorp

City of Waupun

Dane County Department of Planning and Development

Dane County Regional Planning Commission

Federal (Regular)

Federal Energy Regulatory Commission Licensees

Consolidated Paper Corporation, Niagara Division

Dairyland Power Cooperative

Northern States Power Company

Northwoods Hydropower

Wisconsin Electric Power Company

Wisconsin Public Service Corporation

Wisconsin Valley Improvement Company

Fontana/Walworth Water Pollution Control Commission Green Bay Metropolitan Sewerage District

Illinois Department of Transportation

Jefferson County

Kickapoo Reserve

Lac du Flambeau Band of Lake Superior Chippewa

Madison Metropolitan Sewerage District

Menominee Indian Tribe of Wisconsin

Oneida Tribe of Indians of Wisconsin

Rock County Public Works Department

Southeastern Wisconsin Regional Planning Commission Stockbridge-Munsee Band of Mohican Indians

U.S. Army Corps of Engineers

Village of Wittenberg

Walworth County Metropolitan Sewerage District

Wisconsin Department of Natural Resources

PROBLEM: Surface-water information is needed for surveillance, planning, design, hazard warning, operation, and management in water-related fields such as water supply, hydroelectric power, flood control, irrigation, bridge and culvert design, wildlife
LOCATION:

Statewide

PROJECT CHIEF:

Barry K. Holmstrom

PERIOD OF PROJECT:

July 1913-Continuing

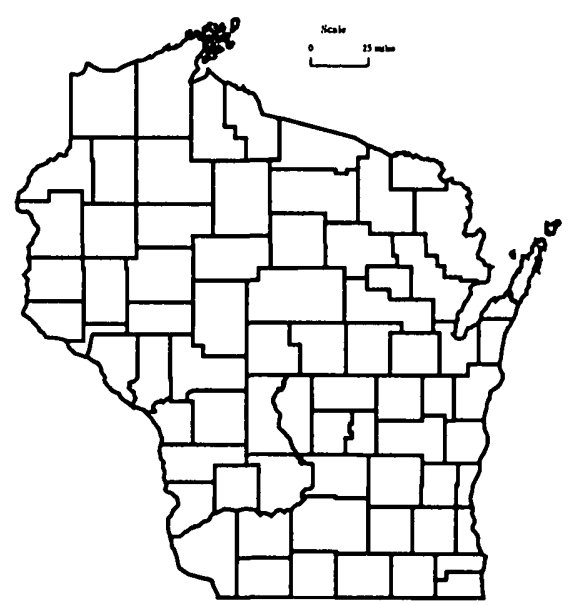


management, pollution abatement, flood-plain management, and water-resources development. An appropriate database is necessary to provide this information.

OBJECTIVE: The objectives of this study are to provide continuous discharge records for selected rivers at specific sites to supply the needs for regulation, analytical studies, definition of statistical properties, trends analysis, determination of the occurrence, and distribution of water in streams for planning. The project is also designed to determine lake levels and to provide discharge for floods, low-flow conditions, and for waterquality investigations. Requests for streamflow data and information relating to streamflow in Wisconsin are answered. Basic data are published annually in the report "Water Resources Data-Wisconsin".

APPROACH: A network of streamflow stations and lake-level stations will be maintained throughout Wisconsin. This includes operating the equipment at the gaging station to record river or lake stage, making periodic discharge measurements at each streamflow station to establish or verify a stage-discharge rating curve, reducing the stage records to instantaneous and daily discharges, compilation of monthly and annual discharges, and preparing data for publication in the annual report "Water Resources Data-Wisconsin".

Requests for streamflow data from other government agencies, consultants, and private parties will be processed.

PROGRESS (July 1999 to June 2000): During the current fiscal year, streamflow data were collected at a total of 110 sites: 18 sites for the Corps of Engineers, 14 sites for the Southeastern Wisconsin Regional Planning Commission, 10 sites for the Wisconsin Department of Natural Resources (WDNR), 8 sites for the Federal program, 4 sites for Federal Energy Commission licensees, 3 sites for the Madison Metropolitan Sewerage District, 3 sites for the Lac du Flambeau Band of Lake Superior Chippewa, and 1 site each for the Bad River Band of Lake Superior Chippewa Indians, Menominee Indian Tribe of Wisconsin, Oneida Tribe of Indians of Wisconsin, Stockbridge-Munsee Band of Mohican Indians, Illinois Department of Transportation, Rock County Public Works Department, Fontana/Walworth Water Pollution Control Commission, Dane County Department of Planning and Development, Walworth County Metropolitan Sewerage District, Dane County Regional Planning Commission, Green Bay Metropolitan Sewerage District, Kickapoo Reserve, and cities of Barron, Beaver Dam, Brookfield, Fort Atkinson, Hillsboro, Peshtigo, Sparta, Thorp, Waupun, and village of Wittenberg. Streamflow data were also collected at 28 sites for agencies working jointly with the USGS. Lakelevel data were collected at two sites for the Dane County Department of Planning and Development, two sites for the Corps of Engineers, one site for the Rock County Public Works Department, and one site for the WDNR.
A map showing the location of all continuous-record streamflow-gaging stations in Wisconsin is shown on page 5 .

Computation of streamflow and lake-level records for all the network stations for the 1999 water year was completed, stored in our WATSTORE computer database, and published in the annual report "Water Resources Data-Wisconsin, water year 1999". More than 300 requests for streamflow information were answered.

PLANS (July 2000 to June 2001): Data will be collected at 114 continuous-streamflow stations (see the following list) and lake levels at 6 stations. Streamflow records will be computed and data published for the 2000 water year. Requests for streamflow information will be answered.

\section{Real-time data can be accessed on the World Wide Web at http://wi.water.usgs.gov}

Discharge data computation and publication is planned to be discontinued for 05369500 Chippewa River at Durand, 05379500 Trempealeau River at Dodge, 05381000 Black River at Neillsville, and 05382000 Black River near Galesville for the 2001 water year. Stage data only will be collected at these four stations. 
SURFACE-WATER GAGING STATIONS EXPECTED TO BE OPERATED IN 2001 FY

\begin{tabular}{|c|c|c|c|c|}
\hline $\begin{array}{l}\text { Station } \\
\text { number }\end{array}$ & Name and location & $\begin{array}{c}\text { Drainage } \\
\text { Area }\end{array}$ & $\begin{array}{l}\text { Period of record } \\
\text { (water year) }\end{array}$ & Cooperator \\
\hline $\begin{array}{l}4646460920 \\
04024430 \\
04025500 \\
04027000\end{array}$ & $\begin{array}{l}52900 \text { Superior Bay, Duluth Ship Canal at Duluth, MN } \\
\text { Nemadji River - South Superior } \\
\text { Bois Brule River - Brule } \\
\text { Bad River - Odanah }\end{array}$ & $\begin{array}{r}4200 \\
420 \\
118 \\
597\end{array}$ & $\begin{array}{l}1994- \\
1974- \\
1943-81,1984- \\
1914-22,1948\end{array}$ & $\begin{array}{l}\text { C of E, Detroit } \\
\text { WDNR } \\
\text { USGS Federal Program } \\
\text { Bad River Band of Lake } \\
\text { Superior Chippewa Indians }\end{array}$ \\
\hline \multirow{7}{*}{$\begin{array}{l}04027500 \\
04029990 \\
04063700 \\
04064500 \\
04065106 \\
04066003 \\
04066030 \\
04066500 \\
04066800\end{array}$} & White River - Ashland & 301 & 1948- & NSPMDNR \\
\hline & Montreal River - Saxon Falls & 262 & 1987 & NSPMDNR \\
\hline & Popple River - Fence & 139 & $1964-$ & USGS Federal Program \\
\hline & $\begin{array}{l}\text { Pine River - Pine River Powerplant - Florence } \\
\text { Menominee River - Niagara }\end{array}$ & $\begin{array}{r}533 \\
2470\end{array}$ & $\begin{array}{l}\text { 1924-76, 1996- } \\
1993-\end{array}$ & $\begin{array}{l}\text { WEPCOMDNR } \\
\text { FERC }\end{array}$ \\
\hline & Menominee River - Pembine & 3140 & 1950 & WEPCONDNR \\
\hline & $\begin{array}{l}\text { Menominee River - White Rapids Dam - Banat, MI } \\
\text { Pike River - Amberg }\end{array}$ & $\begin{array}{r}3190 \\
255\end{array}$ & $\begin{array}{l}1999- \\
1914-70,2000-\end{array}$ & $\begin{array}{l}\text { FERC } \\
\text { USGS Federal Program }\end{array}$ \\
\hline & Menominee River - Koss, MI & 3700 & $\begin{array}{l}\text { 1907-09, 1913-81, } \\
\text { 1998- }\end{array}$ & FERC \\
\hline 04067500 & Menominee River - McAllister & 3930 & $\begin{array}{l}\text { 1945-61, 1979-86 } \\
1988-90,1993-95,\end{array}$ & $\begin{array}{l}\text { WDNR } \\
\text { 1998- }\end{array}$ \\
\hline \multirow{10}{*}{$\begin{array}{l}04067958 \\
04069416 \\
04069500 \\
04071000 \\
04071765 \\
04072150 \\
040073365 \\
04073500 \\
04074950 \\
04077400 \\
04077630\end{array}$} & Peshtigo River - Wabeno & 447 & 1998- & WPSWDNR \\
\hline & Peshtigo River - Porterfield & 1020 & 1998- & FERC \\
\hline & Peshtigo River - Peshtigo & 1080 & 1953- & City of Peshtigo \\
\hline & Oconto River - Gillett & 705 & 1906-09, 1914- & USGS Federal Program \\
\hline & $\begin{array}{l}\text { Oconto River - Oconto } \\
\text { Duck Creek - Howard }\end{array}$ & $\begin{array}{l}966 \\
108\end{array}$ & $\begin{array}{l}\text { 1989-90, 1998- } \\
\text { 1988- }\end{array}$ & $\begin{array}{l}\text { WDNR } \\
\text { Oneida Tribe of Indians of WI }\end{array}$ \\
\hline & Fox River - Princeton & & 2001- & USGS Federal Program \\
\hline & Fox River - Berlin & 1340 & 1898 & $C$ of $E$, Detroit \\
\hline & Wolf River - Langlade & 463 & $1966-79,1981-$ & Menominee Indian Tribe of WI \\
\hline & Wolf River - Shawano & 816 & $1907-09,1911$ & Alliant Utilities/WDNR \\
\hline & Red River - Morgan & 114 & 1993 & $\begin{array}{l}\text { Stockbridge-Munsee Band of } \\
\text { Mohican Indians }\end{array}$ \\
\hline \multirow{12}{*}{$\begin{array}{l}0407809265 \\
04078500 \\
04079000 \\
04082400 \\
04084445 \\
04084500 \\
040851385 \\
04085200 \\
04085395 \\
04085427 \\
04086000 \\
04086500\end{array}$} & Middle Branch Embarrass River - Wittenberg & 76.3 & $1990-$ & Village of Wittenberg \\
\hline & Embarrass River - Embarrass & 384 & $1919-85,1994-$ & USGS Federal Program \\
\hline & Wolf River - New London & 2260 & 1896- & $C$ of $E$, Detroit \\
\hline & Fox River - Oshkosh & 5310 & 1991 & $C$ of $E$, Detroit \\
\hline & Fox River - Appleton & 5950 & 1986- & $C$ of $E$, Detroit \\
\hline & Fox River - Rapide Croche Dam - Wrightstown & 6010 & 1896- & LFRDAWDNR \\
\hline & Fox River - Oil Tank Depot - Green Bay & 6330 & $1989 \cdot$ & Green Bay MSD \\
\hline & Kewaunee River - Kewaunee & 127 & $1964-96,1998-$ & WDNR \\
\hline & S.Br. Manitowoc River - Hayton & 109 & 1993- & WDNR \\
\hline & Manitowoc River - Manitowoc & 526 & 1972-96, 1998- & WDNR \\
\hline & Sheboygan River - Sheboygan & 418 & $1916-24,1951$ & WDNR \\
\hline & Cedar Creek - Cedarburg & 120 & $\begin{array}{l}\text { 1930-70, 73-81, } \\
\text { 1983-87, 1991. }\end{array}$ & WDNR \\
\hline \multirow{17}{*}{$\begin{array}{l}04086600 \\
04087000 \\
04087030 \\
04087088 \\
04087120 \\
04087160 \\
04087204 \\
04087220 \\
04087233 \\
04087240 \\
04087257 \\
05332500 \\
05340500 \\
05341500 \\
05356000 \\
05356500 \\
05357254\end{array}$} & Milwaukee River - Pioneer Road - Cedarburg & 607 & 1982- & SEWRPC \\
\hline & Milwaukee River - Milwaukee & 696 & 1914- & SEWRPC \\
\hline & Menomonee River - Menomonee Falls & 34.7 & $1975-77,1979$ & SEWRPC \\
\hline & Underwood Creek - Wauwatosa & 18.2 & 1975- & SEWRPC \\
\hline & Menomonee River - Wauwatosa & 123 & 1962 & SEWRPC \\
\hline & Kinnickinnic River - Milwaukee & 20.4 & 1976- & SEWRPC \\
\hline & Oak Creek - South Milwaukee & 25 & 1964- & SEWRPC \\
\hline & Root River - Franklin & 49.2 & 1964- & SEWRPC \\
\hline & Root River Canal - Franklin & 57 & 1964- & SEWRPC \\
\hline & Root River - Racine & 190 & 1963 . & SEWRPC \\
\hline & Pike River - Racine & 38.5 & 1972 & SEWRPC \\
\hline & Namekagon River - Trego & 488 & $1928-70,1988$ & NSPMDNR \\
\hline & St. Croix River - St. Croix Falls & 6240 & 1902 & NSPMDNR \\
\hline & Apple River - Somerset & 579 & $1901-70,1987$ & NSPMDNR \\
\hline & Chippewa River - Winter & 790 & 1912 & NSPMDNR \\
\hline & Chippewa River - Bruce & 1650 & 1914- & NSPMDNR \\
\hline & Trout River - CTH H - Boulder Junction & 58.9 & 1999- & $\begin{array}{l}\text { Lac du Flambeau Band of Lake } \\
\text { Superior Chippewa (LDF) }\end{array}$ \\
\hline \multirow{12}{*}{$\begin{array}{l}05357335 \\
05360500 \\
05362000 \\
05365500 \\
05365707 \\
053674464 \\
05368000 \\
05369000 \\
05369500 \\
05370000 \\
05379400 \\
05379500 \\
05381000 \\
\end{array}$} & Bear River - Manitowish Waters & 81.3 & 1991 & LDF \\
\hline & Flambeau River - Bruce & 1860 & 1951. & NSPMDNR, FERC \\
\hline & Jump River - Sheldon & 576 & 1915- & USGS Federal Program \\
\hline & Chippewa River - Chippewa Falls & 5650 & 1888-1983, 1987 & NSPMDNR \\
\hline & North Fork Eau Claire River - Thorp & 51 & 1986 & City of Thorp \\
\hline & Yellow River - Barron & 153 & 1991 & City of Barron \\
\hline & Hay River - Wheeler & 418 & $1951-$ & USGS Federal Program \\
\hline & Red Cedar River - Menomonie & 1770 & $1907-08,1913-$ & NSPMDNR \\
\hline & Chippewa River - Durand & 9010 & 1928- & C of E, St. Paul \\
\hline & Eau Galle River - Spring Valley & 64.1 & 1944- & C of E, St. Paul \\
\hline & Trempealeau River - Arcadia & 606 & 1960-77, 2001- & USGS Federal Program \\
\hline & $\begin{array}{l}\text { Trempealeau River - Dodge } \\
\text { Black River - Neillsville }\end{array}$ & $\begin{array}{l}643 \\
749 \\
\end{array}$ & $\begin{array}{l}1914-19,1934 \\
1905-09,1914\end{array}$ & $\begin{array}{l}\text { C of E, St. Paul } \\
C \text { of E, St. Paul }\end{array}$ \\
\hline
\end{tabular}


SURFACE-WATER GAGING STATIONS EXPECTED TO BE OPERATED IN 2001 FY

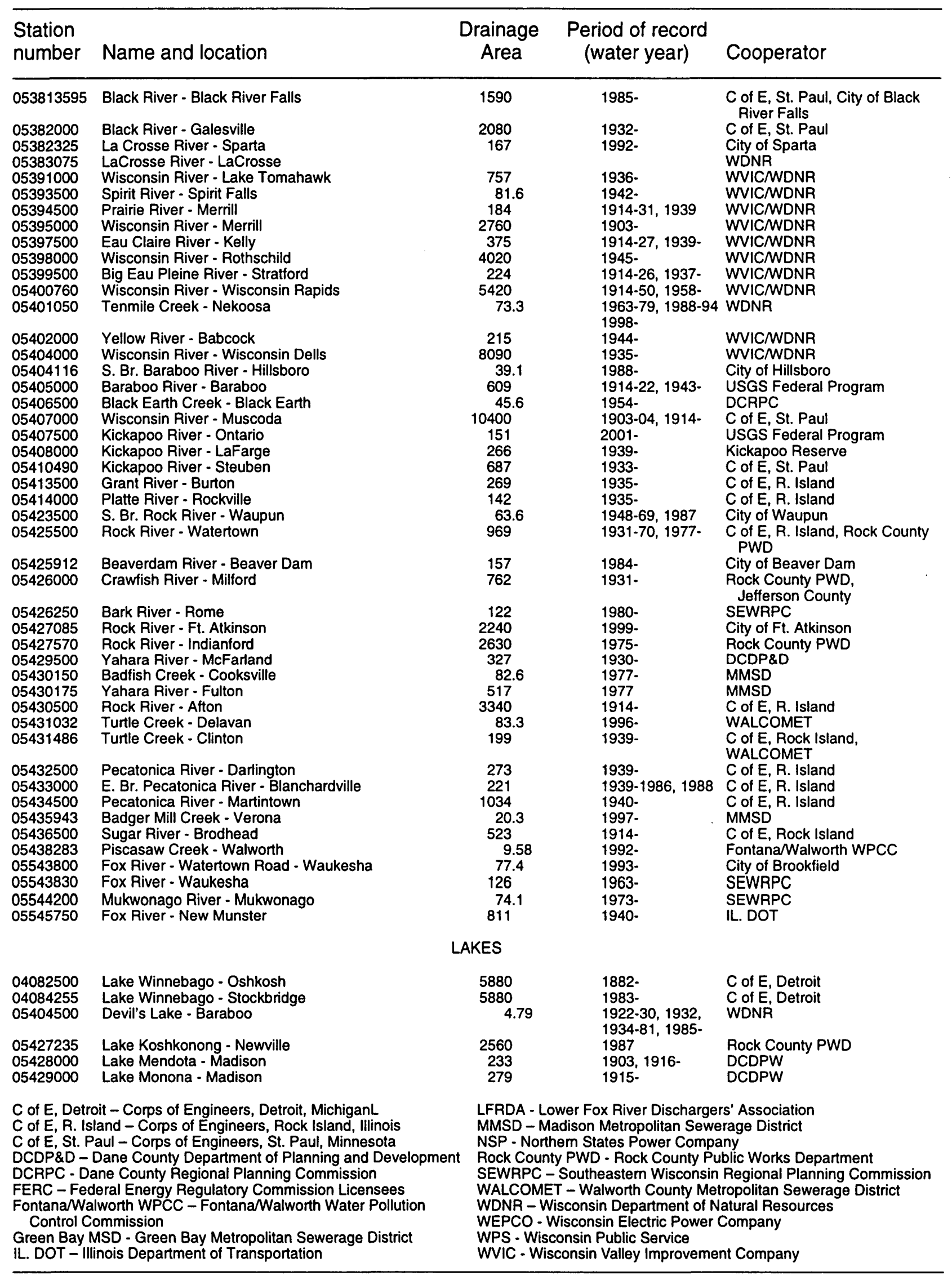




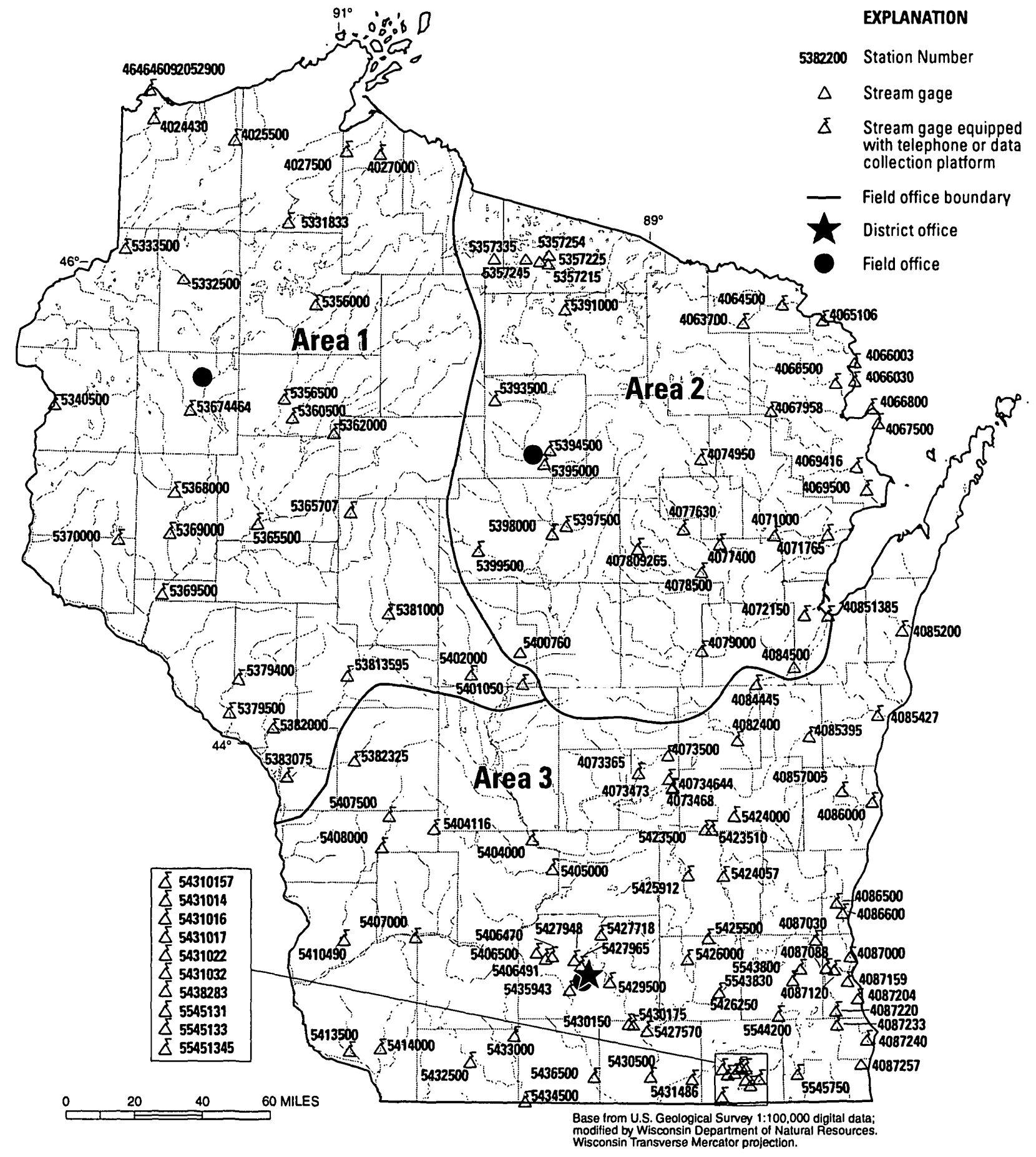

Figure 8. Location of continuous-record data-collection stations. 
The following continuous-record surface-water discharge stations in Wisconsin have been discontinued. Daily streamflow records were collected and published for the period of record, expressed in water years, shown for each station. Those stations with an asterisk $(*)$ after the station number are currently operated as crest-stage partial-record stations. Some of the discontinued project stations with less than three years of record have not been included. Information regarding these stations may be obtained from the District Office at the address given on the back side of the title page of this report.

\section{Discontinued surface-water discharge stations}

$\begin{array}{llll}\text { Station name } & \begin{array}{l}\text { Station } \\ \text { number }\end{array} & \begin{array}{l}\text { Drainage area } \\ \text { (square miles) }\end{array} \quad \text { Period of record }\end{array}$

STREAMS TRIBUTARY TO LAKE SUPERIOR

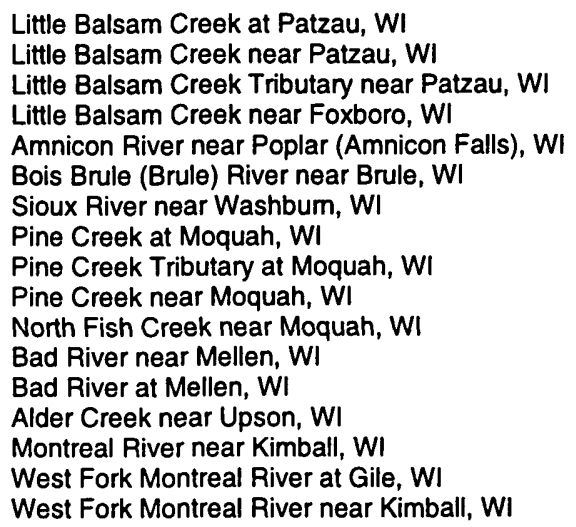

$\begin{array}{lc}04024314 & 4.89 \\ 04024315 & 5.05 \\ 04024318 & 0.60 \\ 04024320 & 3.27 \\ 04025000 & 110 \\ 04026000 & 160 \\ 04026300^{*} & 33.9 \\ 04026347 & 6.20 \\ 04026348 & 0.48 \\ 04026349 & 19.9 \\ 040263491 & 65.4 \\ 04026450^{*} & 82.0 \\ 04026500 & 98.3 \\ 04026870 & 22.2 \\ 04028500 & 100 \\ 04029000 & 75.0 \\ 04029500 & 86.2\end{array}$

STREAMS TRIBUTARY TO LAKE MICHIGAN

North Branch Pine River at Windsor Dam nr Alvin, WI

Pine River near Florence, WI

Pine River below Pine River Power Plant near Florence, WI

Peshtigo River at High Falls near Crivitz, WI

Pensaukee River near Pensaukee, WI

Suamico River at Suamico, WI

Lawrence Creek near Westfield, WI

Grand River near Kingston, WI

West Branch White River near Wautoma, WI

White Creek at Forest Glen Beach near Green Lake, WI

Swamp Creek above Rice Lake at Mole Lake, WI

Swamp Creek below Rice Lake at Mole Lake, WI

Wolf River near White Lake, WI

Evergreen Creek near Langlade, WI

Wolf River above West Branch Wolf River, WI

West Branch Wolf River at Neopit, WI

West Branch Wolf River near Keshena, WI

Little Wolf River near Galloway, WI

Spaulding Creek near Big Falls, WI

Little Wolf River at Royalton, $W$

Emmons Creek near Rural, WI

Storm Sewer to Mirror Lake at Waupaca, WI

Waupaca River near Waupaca, WI

Daggets Creek at Butte Des Morts, WI

West Branch Fond du Lac River at Fond du Lac, WI

East Branch Fond du Lac River near Fond du Lac, WI

Brothertown Creek at Brothertown, WI

East Twin River at Mishicot, WI

Onion River at Hingham, W

Onion River near Sheboygan Falls, WI

Milwaukee River at Kewaskum, WI

East Branch Milwaukee River near New Fane, WI
$04063640^{*}$

04064000

04064500

04068000

04071858

04072000

04072750

04073050

04073405

04073462

04074538

04074548

04075000

04075200*

04075500

04076000

04076500

04079602

$04079700^{*}$

04080000

04080950

04080976

04081000

04081800

04083000

04083500

04084200

04085281

04085813

04085845

04086150

04086200

\section{8}

510

533

537

134
60.7

13.4

73.5

38.9

3.05

46.3

56.8

485

8.09

616

93.2

163

22.6

5.57

507

25.1

0.04

265

10.6

83.1

78.4

5.10

110

37.2

94.1

138

54.1
1976-78

1976-78

1976-78

1977-78

1914-16

1914-17

1965-66

1976-78

1976-78

1976-78

1990-91

1971-75

1948-55

1972-77

1924-26

1918-26, 1943-47

1924-26

$1935-38$

1964-73

1928-62

1911-17

1928-32

1974-79

1964-66

1914-70, 1983-85

1977

1971-74

1916-66, 1983-85

1977

1939-54

1939-54

1976-77

1972-96

$1979-80$

1979-82

1968-81

1968-81 
Discontinued surface-water discharge stations

\begin{tabular}{lccc}
\hline Station name & $\begin{array}{l}\text { Station } \\
\text { number }\end{array}$ & $\begin{array}{c}\text { Drainage area } \\
\text { (square miles) }\end{array}$ & Period of record \\
\hline North Branch Milwaukee River near Fillmore, WI & 04086340 & 148 & $1968-81$ \\
Milwaukee River at Waubeka, WI & 04086360 & 432 & $1968-81,1994$ \\
Mud Lake Outlet near Decker Comer, WI & 04086488 & 7.36 & $1983-84$ \\
Milwaukee River above North Ave. Dam at Milwaukee, WI & 04087010 & 702 & $1975-77$ \\
Menomonee River at Germantown, WI & 04087018 & $1982-84$ & $1976-78$ \\
Jefferson Park Drainageway at Germantown, WI & 04087019 & 1.0 & $1975-79$ \\
Menomonee River at Butler, WI & 04087040 & 60.6 & $1975-79$ \\
Little Menomonee River near Freistadt, WI & $04087050^{*}$ & 8.0 & $1975-80,1990$ \\
Noyes Creek at Milwaukee, WI & 04087060 & 1.94 & $1975-77$ \\
Little Menomonee River at Milwaukee, WI & 04087070 & 19.7 & $1975-81$ \\
Honey Creek at Wauwatosa, WI & 04087119 & 10.3 & $1975-79$ \\
Schoonmaker Creek at Wauwatosa, WI & 04087125 & 1.94 & $1975-77$ \\
Hawley Road Storm Sewer at Milwaukee, WI & 04087130 & 1.83 & $1982-84$ \\
Menomonee River at Milwaukee, WI & 04087138 & 134 & $1976-83$
\end{tabular}

\section{ST. CROIX RIVER BASIN}

Namekagon River at Trego, WI

Loon Creek near Danbury, WI

Bashaw Brook near Shell Lake, WI

Clam River near Webster, WI

St. Croix River near Grantsburg, WI

Wood River near Grantsburg, WI

Rice Creek near Balsam Lake, WI

Balsam Branch at Balsam Lake, WI

Kinnickinnic River near River Falls, WI
05332000

05335010

$05335380^{*}$

05335500

05336000

05339000

05341375

05341402

05342000

\section{CHIPPEWA RIVER BASIN}

West Fork Chippewa River at Lessards, nr Winter, WI

Couderay River near Couderay, WI

Flambeau River at Flambeau Flowage (Flambeau Reservoir), WI05357500

Flambeau River near Butternut, WI

05358000

05358300

05358500

05359500

$05359600^{*}$

05360000

05361000

05361500

05362500

05363000

05363500

05363700

$05364000^{*}$

05364500*

05364850

05365000

05366000

05366300

$05366500^{*}$

05367000

05367425

05367426

05367500

05369900

05369945

05369955

05369970

05369985

05370500

Eau Galle River near Woodville, WI

French Creek near Spring Valley, WI

Lousy Creek near Spring Valley, WI

Lohn Creek near Spring Valley, WI
Eau Galle River at Eimwood, WI
433

17.6

26.6

361

2,980

185

12.5

165
1914-27

1970-71

1964-66

1941-42

1923-70

$1939-40$

1988-89

1988-90

1917-21

BUFFALO RIVER BASIN

Buffalo River near Tell, WI

05372000

406

1933-51

1912.16

1981-83

1927-61

1914-39

1971-75

1929-75

$1929-75$

1964-66

1903-06, 1914-61

1944-49

1944-54

$1943-49$

1944-45

$1944-45$

1962-63

1943-61

1944-52

1987-89

1943-55

1914-26

1980

1943.55

1903-09, 1944-54

1966-70

$1971-73$

1914-80, 1989-90

1978-83

$1982-83,1986-96$

1981-83

1981-83

1981-83

1943-54 


\section{Discontinued surface-water discharge stations}

\begin{tabular}{llll}
\hline Station name & $\begin{array}{l}\text { Station } \\
\text { number }\end{array}$ & $\begin{array}{l}\text { Drainage area } \\
\text { (square miles) }\end{array} \quad$ Period of record
\end{tabular}

TREMPEALEAU RIVER BASIN

Bruce Valley Creek near Pleasantville, WI Elk Creek near Independence, WI

Trempealeau River near Trempealeau, WI

Black River at Medford, WI

Poplar River near Owen, WI

Little LaCrosse River near Leon, WI

LaCrosse River near West Salem, WI

Spring Coulee Creek near Coon Valley, WI

Coon Creek at Coon Valley, WI

Coon Creek near Stoddard, WI

North Fork Bad Axe River near Genoa, WI
05379288

05379305

05380000

\section{BLACK RIVER BASIN}

05380806

$05380900^{*}$

48.1

155

\section{LA CROSSE RIVER BASIN}

05382500

05383000

76.9

396

\section{COON CREEK BASIN}

05386490

05386500

05386999

9.01

77.2

120

\section{BAD AXE RIVER BASIN}

05387100*

80.8

\section{WISCONSIN RIVER BASIN}

Wisconsin River at Conover, WI

05390180

Pelican River near Rhinelander, WI

05391226

05392000

$05392350^{*}$

05392400

05393000

05394000

05396000

05396500

05397000

05397110

05398500

05399000

05399431

05400000

05400500

05400600

05400650

05400840

05400853

05401020

05401100

05401500

05401510

05401535

05402500

05403000

05403500

$05403630^{*}$

$05403700^{*}$

$05404200^{*}$

05406000

Narrows Creek at Loganville, WI

Wisconsin River at Prairie du Sac, WI

05406573

Trout Creek at Twin Parks Dam $8 \mathrm{nr}$ Barneveld, WI

05406574

05406575

05406577

05406590

05406640

05408500

05409000

05409500
177

101

1,220
31.1

422

544

82.2

303

79.1

81.5

185

27.4

78.1

11.3

4,530

145

2.24

19.0

75.0

53.1

9.73

91.1

5,990

9.61

52.8

392

491

507

11.2

44.9

40.1

9,180

8.37

9.02
12.1

13.5

7.57

16.8

8.44

106

530
$1964-66$

1980

1980

1932-34

1984-87

1964-66

1934-61, 1979-81 1914-70

1979-81

1934-40, 1978-81

1934-40, 1979-81

1967-71

1976-79

1906-61

1964-66

1915-27, 1929

1930-73

1953-61

1925-57

1914-16

1949-55

1975-81

1944-52

1941-54

1977.79

1921-42

1914-20, 1944-52

$1959-75$

1959-87

1964-67

1964-67

1964-73

1964-79

1903-14, 1944-50

1964-67

1964-78

1927-40

1941-57

1944-87, 1994

1971.77

1957-65, 1971-80

1964-66

1946-54

1976-78

1976-79

1976-78

1976-79

1976-78

1968-69, 1970-75

1955-69

1939

1939 


\section{Discontinued surface-water discharge stations}

Station name
Station

number
Drainage area

(square miles)
Period of record
North Fork Nederlo Creek near Gays Mills, WI

Nederlo Creek near Gays Mills, WI

Kickapoo River at Gays Mills, WI

Pigeon Creek near Lancaster, WI

Rattlesnake Creek near Beetown, WI
05409830

05409890

05410000

\section{GRANT RIVER BASIN}

05413400*

05413451

\section{GALENA RIVER BASIN}

Little Platte River near Platteville, WI

Sinsinawa River near Hazel Green, WI

Pats Creek near Belmont, WI

Madden Branch Tributary near Belmont, WI

Madden Branch near Meekers Grove, WI

Galena River at Buncombe, WI

Apple River near Shullsburg, WI

West Branch Rock River near Waupun, WI

West Branch Rock River at County Trunk Highway D near Waupun, WI

East Branch Rock River near Mayville, WI

Rock River at Hustisford, WI

Johnson Creek near Johnson Creek, WI

Johnson Creek near Johnson Creek, WI

Pratt Creek near Juneau, WI

Rock River at Jefferson, WI

Whitewater Creek near Whitewater, WI

Whitewater Creek at Millis Road near Whitewater, WI

Whitewater Creek at Whitewater, WI

Koshkonong Creek near Rockdale, WI

Token Creek near Madison, WI

Sixmile Creek near Waunakee, Wi

Pheasant Branch at Airport Road near Middleton, WI

South Fork Pheasant Branch at Highway 14 near Middleton, WI 05427945

Pheasant Branch at Century Avenue at Middleton, WI 05427950

Pheasant Branch at mouth at Middleton, WI

Willow Creek at Madison, WI

Olbrich Park Storm Ditch at Madison, WI

Manitou Way Storm Sewer at Madison, WI

Nakoma Storm Sewer at Madison, WI

Lake Wingra Outlet at Madison, WI

Door Creek near Cottage Grove, WI

Yahara River near Edgerton, WI

Oregon Branch at Oregon, WI

Badfish Creek at County Highway A near Stoughton, WI

Badfish Creek near Stoughton, WI

Jackson Creek at Petrie Road near Elkhorn, WI

Livingston Branch, Pecatonica River near Livingston, WI

Yellowstone River near Blanchardville, WI

Pecatonica River at Dill, WI

Steiner Branch near Waldwick, WI

Skinner Creek at Skinner Hollow Road near Monroe, WI

Skinner Creek at Klondyke Road near Monroe, WI

West Branch Sugar River near Mount Vernon, WI

Mount Vernon Creek near Mount Vernon, WI
05414213

05414800

05414894

$05414915^{*}$

05414920

05415000

\section{APPLE RIVER BASIN}

05418731

\section{ROCK RIVER BASIN}

05423000

05423100

05424000

05424082

05425537

05425539

05425928

05426031

05426500

05426900

05427000

05427507

05427800*

05427900

05427943

05427952

05428665

05429040

05429050

05429120

05429580

05430000

05430030

05430095

05430100

05431014

05432055

$05433500^{*}$

05434000

05433510

05434235

05434240

05435980

05436000

2.21
9.46
617

1968-79

1968-80

1914-34, 1964-77

1964-66

1990-91

1987-90

1987-90

1981.82

1981-82

1981-82

1939-92

1981.82

1949-70, 1978-81

1978-81

1949-70

1978-85

1978-80

1978-80

1978-80

1978-94

1926-28, 1946-54

1978-81

1926-28, 1946-54

1977-82

1964-66, 1976-81

1976-82

1977-81

1978-81

1977-81

1978-81

1974-83

1976-80

1971-77

1972-77

1971-77

1976-79

1917-18

1979-81

$1956-66,1986-88$

1956-66

1984-95

1987-91

$1954-65,1978-79$

1914-19

1978-79

1978-81

1978-81

1979-80

1954-65, 1976-80

\section{ILLINOIS RIVER BASIN}




\section{CRANDON GROUND WATER, WI 00201}

\author{
COOPERATOR: \\ Wisconsin Department of \\ Natural Resources \\ LOCATION: \\ Forest County \\ PROJECT CHIEF:
James T. Krohelski \\ PERIOD OF PROJECT: \\ October 1994-Continuing
}

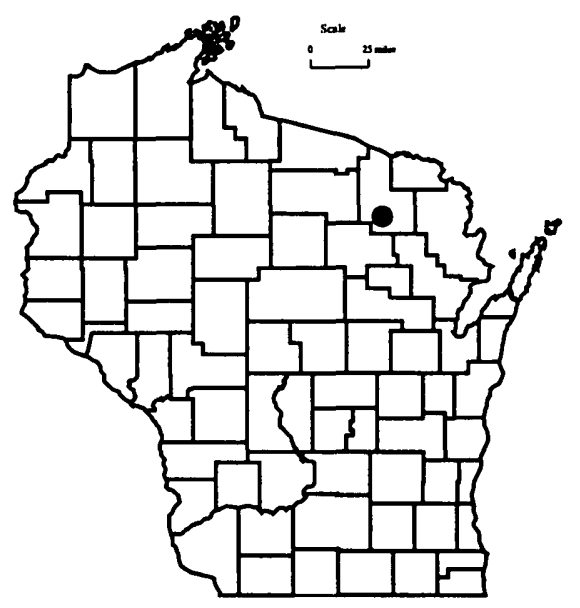

PROBLEM: A large underground zinc-copper mine is being proposed at a site about five miles south of Crandon, Wisconsin, in Forest County. The Wisconsin Department of Natural Resources (WDNR) requested that District staff review the development of a ground-water-flow model and associated hydrologic documents as part of a permitting process for the proposed mine.

OBJECTIVE: The objective is to review documents related to water resources submitted to WDNR from the Nicolet Mining Company and their consultants and to make suggestions to WDNR on studies and approaches that will improve the understanding of the hydrology and effects of mining on the water resources in the vicinity of the proposed mine.

APPROACH: The schedule for review of documents will be mutually agreed upon between WDNR and USGS.

PROGRESS (July 1999 to June 2000): Ground-water-flow model calibration and predictive simulations, based on the calibrated ground-water model were completed. Monitoring of lake stage and shallow ground-water levels adjacent to Little Sand Lake and Skunk Lake was continued.

PLANS (July 2000 to June 2001): Documents will be reviewed and meetings attended at the request of the WDNR. Descriptions of model development, calibration and simulation results of the flow model will be summarized and submitted to the WDNR. Monitoring of lake stage and shallow ground-water levels adjacent to Little Sand Lake will be continued. 


\section{WISCONSIN WATER-USE DATA FILE, WI 00700}

PROBLEM: The need for reliable water-use data by State and Federal planning agencies is increasing as the competition for use of the State's water resources increases. Water-use data in a standardized format needs to be available to assist in making decisions on future water use.

OBJECTIVE: The purpose of this project is to collect accurate and complete data on Wisconsin's water use, store data in the State Water-Use Data System (SWUDS), and prepare periodic reports on water use in the State.

APPROACH: Sources of water-use information will be evaluated. The best available data will be entered into SWUDS. Efforts will be made to upgrade the accuracy of the water-use data.

PROGRESS (July 1999 to June 2000): SWUDS was updated with current water-use information. These data included high-capacity well data and information on discharge from sewagetreatment plants in the State. Reformatting programs were written or updated as needed for entering data from other agencies into SWUDS.

PLANS (July 2000 to June 2001): Plans include: (1) continue to update and maintain SWUDS with current water-use data, (2) supply water-use data for water-resources studies currently being conducted in the State and (3) work with the Department of Natural Resources and the Wisconsin Geological and Natural History Survey in a joint effort to establish a water-use database that can be used and updated by each agency.

\section{REPORTS:}

Ellefson, B.R., Fan, C.H., and Ripley, J.L., 1995, Water use in Wisconsin, 1995: U.S. Geological Survey Open-File Report 97-356, 1 sheet, scale 1:5,000,000.

Ellefson, B.R., Sabin, T.J., Krohelski, J.T., 1993, Water use in Wisconsin, 1990: U.S. Geological Survey Open-File Report 93118,1 sheet, scale $1: 5,000,000$.

Ellefson, B.R., Rury, K.S., and Krohelski, J.T., 1988, Water-use in Wisconsin, 1985: U.S. Geological Survey Open-File Report 87-699, 1 sheet, scale 1:5,000,000.

U.S. Geological Survey, 1990, National Water Summary, 1987Hydrologic events and water supply and use: U.S. Geological Survey Water-Supply Paper 2350, 553 p.

Krohelski, J.T., Ellefson, B.R., and Storlie, C.A., 1987, Estimated use of ground water for irrigation in Wisconsin, 1984: U.S. Geological Survey Water-Resources Investigations Report 86-4079, 12 p., 1 pl.

Lawrence, C.L., and Ellefson, B.R., 1984, Public-supply pumpage in Wisconsin, by aquifer: U.S. Geological Survey Open-File Report 83-931, 40 p.

1982, Water use in Wisconsin, 1979: U.S. Geological Survey Open-File Report 82-444, 98 p.
COOPERATOR:

Wisconsin Department of

Natural Resources

LOCATION:

Statewide

PROJECT CHIEF:

Bernard R. Ellefson

PERIOD OF PROJECT:

March 1978-Continuing

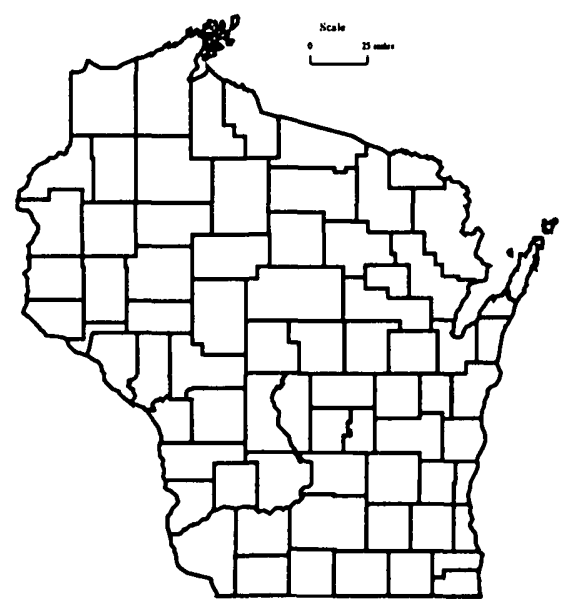




\section{FOX RIVER REMEDIATION, WI 14500}

\section{COOPERATOR:}

\section{Wisconsin Department of Natural Resources}

\section{LOCATION: Outagamie County}

\section{PROJECT CHIEF: Jeffrey Steuer}

\section{PERIOD OF PROJECT: August 1998 to October 2000}

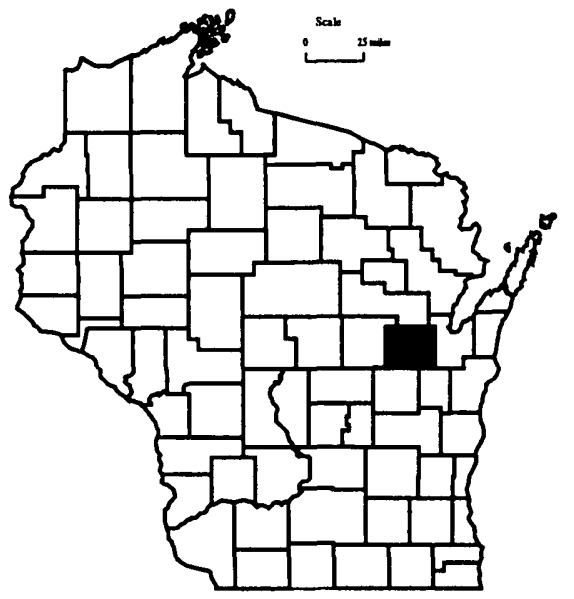

PROBLEM: Several Fox River bottom sediment deposits are being considered for remediation based upon high PCB concentrations. The pilot remediation project at deposit "N" (Kimberly) began in November 1998 and, in August 1999, pre-dredge sampling commenced at the Sediment Management Unit (SMU) 56_57 (Green Bay). There is a need, as part of the Fox River Remediation Assessment Team (FRRAT) efforts, to monitor and collect environmental data before, during, and after the remediation operation.

OBJECTIVE: Monitoring and sampling will be conducted to meet the project Quality Assurance Project Plan objectives. The objectives are to (1) evaluate baseline conditions prior to dredging activities, (2) evaluate short-term impacts, including PCB mass fluxes during dredge activities, and (3) evaluate conditions following the completion of dredge-related activities.

APPROACH: Deposit "N"-The baseline investigation consists of water column samples collected at four upstream locations and four downstream locations prior to the commencement of dredging. Bottom sediment samples will be collected from a minimum of 30 locations in Deposit $\mathrm{N}$ and an intermediate zone located between the sediment deposit and the silt-containment barrier.

Evaluation of short-term impact includes water-column sampling at four upstream and four downstream locations, dredge slurry samples and continuous-flow monitoring, composite samples of all on-shore processing locations, composite samples of processed solids for landfill disposal, samples of filter media, and treated carriage water samples.

Evaluation of long-term impacts will include collecting sediment core samples from the same locations as the pre-dredge sample sites and an intermediate zone characterization using visual reconnaissance and sampling.

SMU 56_57-The baseline investigation consists of water-column samples collected at four upstream locations and five downstream locations prior to the commencement of dredging.

Evaluation of short-term impact includes water-column sampling at four upstream and five downstream locations, dredge slurry samples with continuous-flow monitoring and composite samples of processed and treated carriage water samples.

PROGRESS (July 1999 to June 2000): Deposit "N"-Preand post-dredge cores have been collected and processed at 30 locations along with the intermediate zone. Over 90 PCB samples, 800 TSS samples, and over 6,400 water-quality measurements have been collected at the water-column sites. Shore-side (remediation process) samples and slurry flow data have been collected for 29 continuous days. The USGS mercury lab has completed the bottom sediment and remediation process sample analyses. The data analyses and draft report have been written evaluating the water-column transport and the shore-side processes. 
SMU 56_57-Over 90 PCB samples, 800 TSS samples, and over 6,400 water-quality measurements have been collected at the watercolumn sites. Assistance was provided in the slurry sampling and five 80 -liter effluent samples were processed. Data analysis has commenced.

PLANS (July 2000 to June 2001): SMU 56_57 data analysis and report writing will be conducted in conjunction with the FRRAT. 


\section{TRENDS IN WATER QUALITY AND STREAM HABITAT FOR PRIORITY WATERSHEDS, WI 17202-17204, 17213}

COOPERATOR:

Wisconsin Department of Natural Resources

\section{LOCATION:}

Priority watersheds in Brown, Buffalo, Dane, Grant, Milwaukee and Sheboygan Counties

PROJECT CHIEF:

David J. Graczyk

Steven R. Corsi

Judy Wierl

PERIOD OF PROJECT:

October 1990-Continuing

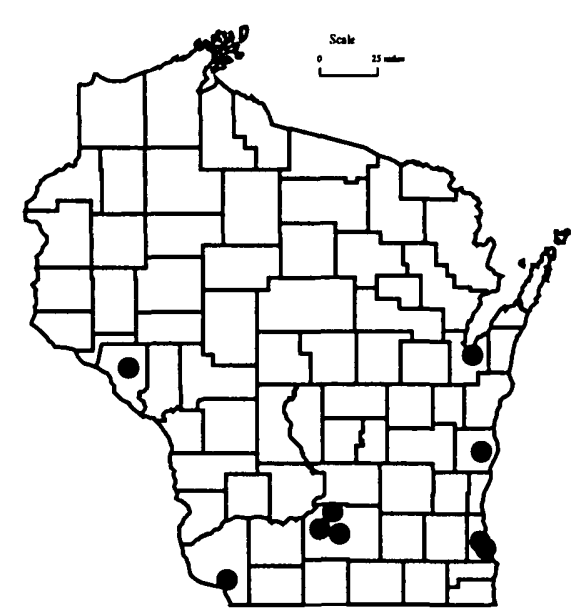

PROBLEM: An evaluation strategy is needed to assess the effectiveness of nonpoint-source pollution control measures in priority watersheds. Several important processes require research including the role of ground water in nonpoint-source contamination, factors leading to dissolved-oxygen reduction in a stream during runoff events, and the impact of management practices on bedload transport. Several techniques need to be developed and/or refined, such as detecting trends in stream-water chemistry, sampling of fish and fish habitat, relation between fish/fish habitat and changes resulting from watershed management practices, and use of habitat models for determining impact of watershed management on fish populations.

OBJECTIVE: The overall objective of this project is to determine the trends in water quality for 10 sites during and after implementation of improved land-management practices in 7 priority watersheds.

APPROACH: Ten streams were selected in seven different priority watersheds. Continuous-record streamflow, water temperature, and dissolved-oxygen gaging stations were installed at each stream site. Water-quality samples will be collected during events and low flows and analyzed for selected constituents. Landuse inventories will be taken each year to help determine the cause of any changes in water quality.

PROGRESS (July 1999 to June 2000): Streamflow and water-quality monitoring were continued at three sites in the priority watersheds. Water-quality loads were calculated for selected parameters and storm periods. All the data were summarized and published in the report "Water-Resources Data-Wisconsin". Landuse inventories were completed for each basin.

PLANS (July 2000 to June 2001): Streamflow and waterquality monitoring will be continued at one site. Two sites will be monitored for streamflow and water quality beginning in October 2000 , with the possibility of a third site. Water-quality loads for selected parameters and storm periods will be calculated and compared to data collected in previous years. The data will be analyzed to determine if there are any apparent trends in water quality during implementation of best management plans. At one site, water-quality samples will be collected weekly during the period of April-October, biweekly in March and November, and monthly during December, January, and February. Land use will be updated for each basin. Report on post monitoring of two sites discontinued in 1998.

\section{REPORTS:}

Wierl, J.A., Giddings, E.M., and Bannerman, R.T., 1998, Evaluation of a method for comparing phosphorus loads from barnyards and croplands in Otter Creek Watershed, Wisconsin, U.S. Geological Survey Fact Sheet 168-98, 4 p. 
Corsi, S.R., Graczyk, D.J., Owens, D.W., and Bannerman, R.T., 1997, Unit-area loads of suspended sediment, suspended solids, and total phosphorus from small watersheds in Wisconsin: U.S. Geological Survey Fact Sheet 195-97, 4 p.

Rappold, K.F., Wierl, J.A., and Amerson, F.U., 1997, Watershed characteristics and land management in the nonpoint-source evaluation monitoring watersheds in Wisconsin: U.S. Geological Survey Open-File Report 97-119, 39 p.

Wierl, J.A., Rappold, K.F., and Amerson, F.U., 1996, Summary of the land-use inventory for the nonpoint-source evaluation monitoring watershed in Wisconsin: U.S. Geological Survey OpenFile Report 96-123, 23 p.

Greb, Steven R., and Graczyk, David J., 1995, Frequency-duration analysis of dissolved-oxygen concentrations in two southwestern Wisconsin streams, Water Resources Bulletin v. 31, no. 3, p. 431-438.

Walker, John F., and Graczyk, David J., 1993, Preliminary evaluation of effects of best management practices in the Black Earth Creek, Wisconsin, priority watershed: Water Science Technology, v. 28 , no. 3-5, p. 539-548. 
COOPERATOR:

Wisconsin Department of Natural Resources

LOCATION:

State of Wisconsin

PROJECT CHIEF:

John F. Walker

PERIOD OF PROJECT: October 1989 to September 2000
PROBLEM: To date, the effectiveness of best management practices (BMPs) in Wisconsin has not been determined. The natural variability of water-quality data complicates the detection of changes due to BMP implementation. Research is needed to identify techniques for detecting changes due to BMP implementation and applying the techniques to before and after data.

OBJECTIVE: The objective is to investigate statistical analysis techniques for assessing trends in water quality due to Best Management Practice (BMP) implementation using data from other states. The effectiveness of BMPs in two urban basins and seven rural basins in Wisconsin will be determined using the identified statistical techniques.

APPROACH: A comprehensive literature search will be conducted to identify viable statistical analysis techniques and needs for method modification or development. Data for several rural and urban basins in other states will be compiled and used to test the selected techniques. Storm loads of total-suspended solids and total phosphorus will be computed and used along with rainfall data and land-use information to assess the effectiveness of the BMPs in several basins in Wisconsin.

PROGRESS (July 1999 to June 2000): Storm-load data through 1998 water year was compiled for annual report. Annual report was completed and sent out for review. Analysis of pre- and post-BMP data for Brewery and Garfoot Creeks began. Final report for Black Earth Creek watershed was started.

PLANS (July 2000 to June 2001): The annual report describing results of statistical analysis for data collected through the 1998 water year will be published. Report describing final results for the Black Earth Creek watershed will be completed and published.

\section{REPORTS:}

Owens, D.W., Corsi, S.R., and Rappold, K.F., 1997, Evaluation of nonpoint-source contamination, Wisconsin: selected data for water year 1995, U.S. Geological Survey Open-File Report 96$661 \mathrm{~A}$.

Walker, J.F., Graczyk, D.J., Corsi, S.R., Owens, D.W., and Wierl, J.A., 1995, Evaluation of nonpoint-source contamination, Wisconsin: land-use and best management practices inventory, selected streamwater-quality data, urban-watershed quality assurance and quality control, constituent loads in rural streams, and snowmelt-runoff analysis, water year 1994: U.S. Geological Survey Open-File Report 95-320, 21 p.

Corsi, S.R., Walker, J.F., Graczyk, D.J., Greb, S.R., Owens, D.W., and Rappold, K.F., 1995, Evaluation of nonpoint-source contamination, Wisconsin: selected streamwater-quality data, landuse and best-management practices inventory, and quality assurance and quality control, water year 1993: U.S. Geological Survey Open-File Report 94-707, 57 p. 
Walker, J.F., 1994, Statistical techniques for assessing water-quality effects of BMPs, ASCE J. of Irrigation and Drainage Engineering, v. 120 , no. 2, p. 334-347.

Walker, J.F., and Graczyk, D.J., 1993, Preliminary evaluation of effects of best management practices in the Black Earth Creek, Wisconsin, priority watershed: Water Science and Technology, v. 28 , no. $3-5$, p. $539-548$.

Walker, J.F., 1993, Techniques for detecting effects of urban and rural land-use practices on stream-water chemistry inlected watersheds in Texas, Minnesota, and Illinois: U.S. Geological Survey Open-File Report 93-130, 16 p.

Graczyk, D.J., Walker, J.F., Greb, S.R., Corsi, S.R., Owens, D.W., 1993, Evaluation of nonpoint-source contamination, Wisconsin: Selected data for 1992 water year: U.S. Geological Survey Open-File Report 93-630, 48 p. 


\section{SINGLE SOURCE SITES, WI 17214}

\author{
COOPERATOR: \\ Wisconsin Department of \\ Natural Resources \\ LOCATION: \\ State of Wisconsin \\ PROJECT CHIEF: \\ Todd D. Stuntebeck
}

\section{PERIOD OF PROJECT: March 1994-Continuing}

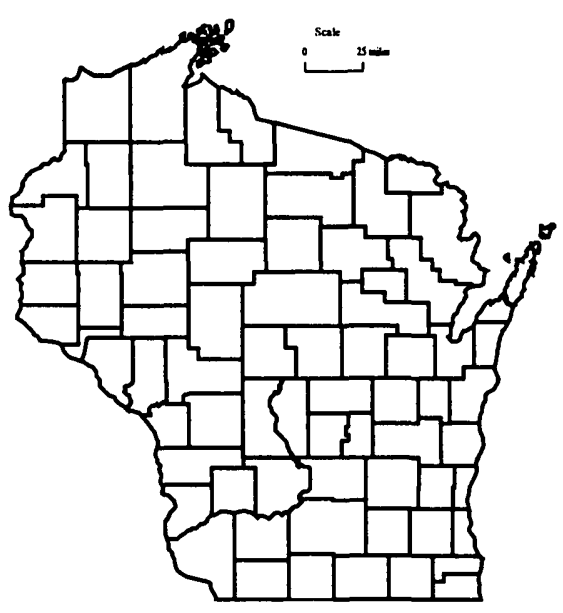

PROBLEM: Much work has been done to assess the effectiveness of nonpoint-source pollution-control strategies known as best management practices (BMPs). Most of this work to date has had a basin-wide scope and is focused on evaluating the cumulative effectiveness of several different types of BMPs. Research targeted at evaluating the effectiveness of a single type of BMP would assist resource managers responsible for planning BMP implementation programs.

OBJECTIVE: The objective is to determine the significance of a single nonpoint-pollution source and evaluate the effectiveness of BMPs in treating that same source.

APPROACH: Water-quality samples will be collected upstream and downstream from a single nonpoint-pollution source before and after implementation of BMPs. Water-quality samples are generally collected biweekly during open-water periods, and monthly during the winter months. In addition, water-quality samples are collected with automated water samplers during selected periods of storm runoff. Water-surface levels are continuously monitored at the sites, and a continuous discharge record is determined from water-surface/discharge relations.

Two barnyard-runoff sites have been fully investigated-Otter Creek in the Sheboygan River Priority Watershed and Halfway Prairie Creek in the Black Earth Creek Priority Watershed. The study concluded that implementation of barnyard BMPs at each site has significantly reduced the loadings of most constituents coming from the barnyards. Currently two additional sites are being investigatedParsons Creek in the Lake Winnebago Priority Watershed and Hutchinson Creek in the Buffalo River Watershed. Each of these sites is designed to evaluate both a barnyard BMP and a streambank erosion BMP.

PROGRESS (July 1999 to June 2000): Samples were collected for two storm-runoff periods at Parsons Creek. Streambank stabilization work was completed in September 1999. Water samples for one snowmelt period have been collected for the first post-BMP period. Water discharge, water temperature, rainfall records and water-quality loads have been worked up for water years 1998 and 1999 for the upstream, middle, and downstream sites and will be published in the 2000 data report.

Samples were collected for four storm-runoff periods at Hutchinson Creek. Baseflow samples were collected according to schedule and measurements of streamflow were made when appropriate. 
PLANS (July 2000 to June 2001): Biweekly baseflow and storm-runoff samples will be collected at Parsons Creek. Stormevent data analysis for pre-BMP period at Parsons Creek will begin. Sampling will be discontinued at Hutchinson Creek after June 1, 2000, due to site limitations. Equipment will be installed and sampling will begin at a site in LaCrosse County to evaluate the effectiveness of rotational grazing.

\section{REPORTS:}

Stuntebeck, T.D., and Bannerman, R.T., 1998, Effectiveness of barnyard best management practices in Wisconsin: U.S. Geological Survey Fact Sheet 051-98, 4 p.

Stuntebeck, T.D., 1995, Evaluating barnyard best management practices in Wisconsin using upstream-downstream monitoring: U.S. Geological Survey Fact Sheet 221-95, 4 p. 


\section{MULTI-STREAM EXPERIMENTAL DESIGN, WI 17223}

\author{
COOPERATOR: \\ Wisconsin Department of \\ Natural Resources

\section{LOCATION:} \\ Fond du Lac, Manitowoc, Ozau- \\ kee, Sheboygan, Washington, \\ and Walworth Counties
}

\section{PROJECT CHIEF: John F. Walker}

\section{PERIOD OF PROJECT:} October 1997 to June 2000

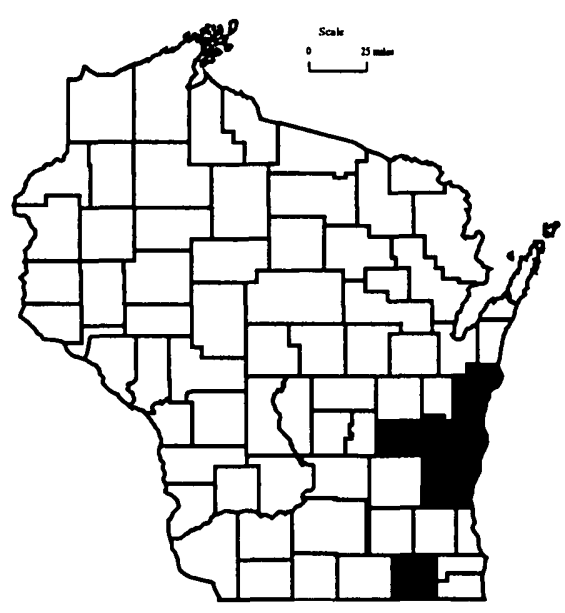

PROBLEM: The amount of best management practice (BMP) implementation at evaluation monitoring sites is currently much less than anticipated, and implementation is taking longer than expected. Results on a shorter time scale are needed to evaluate the overall nonpoint-source program.

OBJECTIVE: The objective is to investigate feasibility of sampling a large number of sites (20-60) for a short period of time (1-2 years) to determine the effectiveness of BMPs.

APPROACH: The sites to be considered are chosen to cover a wide range of BMP implementation. For selected evaluation-monitoring sites, annual loads will be computed with a reduced data set and compared to the actual load to determine uncertainty in annual loads for a particular sampling scheme. A statistical analysis will determine the minimum number of sites needed to demonstrate a significant relation between load reduction and BMP implementation.

PROGRESS (July 1999 to June 2000): Data collection at the eight index stations was completed through November 1999. Daily streamflow records and annual sediment and phosphorus loads at the eight index sites were estimated. The accuracy of estimated daily records from the index-site method was evaluated.

PLANS (July 2000 to June 2001): The accuracy of annual loads using a combination of index sites and the sampling strategies determined previously (Robertson and Roerish) was evaluated. Overall statistical analysis evaluating multi-stream approach for evaluation of BMP effectiveness was performed. Results will be published in an open-file report.

\section{REPORTS:}

Robertson, Dale M., and Roerish, Eric D., Influence of different sampling strategies on load estimations for small streams, journal article (submitted to Water Resources Research). 


\section{HYDROLOGY AND WATER QUALITY OF THREE PASTURES IN SOUTHWESTERN WISCONSIN, WI 17229}

PROBLEM: Nonpoint-source pollution is a major concern in Wisconsin. There are approximately 24,000 dairy farms in Wisconsin which may be sources of sediment, nutrients and pesticides to surface and ground water. Managed Intensive Rotational Grazing (MIRG) is a system that uses pastures as a major source of feed for milking cows (Jackson-Smith and others, 1996). MIRG farmers rely on pastures for their dairy herds' forage needs and move their cows to a new pasture at least once a week (Jackson-Smith and others, 1996). In 1992, roughly 7 percent of Wisconsin dairy farms used MIRG but, in 1994, 14 percent of Wisconsin dairy farms used MIRG (Jackson-Smith and others, 1996). MIRG can be used as a best management practice (BMP) and may reduce the amount of sediments, nutrients and pesticides to receiving waters. In a study in Oklahoma, rotational grazed pastures evidenced a reduction in average annual runoff and sediment discharges when compared to a continuously grazed basin (Menzel and others, 1978).

This study will compare surface-water runoff and water quality from three small pastured watersheds. The pastures will be located at the USDA Dairy Forage Research Center at Prairie du Sac.

OBJECTIVE: The overall objective of this study is to determine differences in quantity and quality of surface-water runoff from three different pasture-management strategies. These strategies consist of a variety of practices which are available to pasture managers, both during the growing and dormant seasons. Combinations of management practices have been chosen to represent commonly used strategies. In addition to examining differences in overall management strategies, differences related to individual seasonal practices will be determined. A secondary objective will be to determine a water budget for each pasture. The water budget will be determined by measuring surface-water runoff and precipitation. Evaporation and transpiration will be estimated by using empirical equations and ground-water flow will be estimated as a residual.

APPROACH: The management practices to be examined include (1) intensive rotational grazing and continuous grazing during the growing season; (2) pasture "stockpiling" during late summer and continued grazing throughout the summer; and (3) two outwintering practices and no outwintering.

An artificial hydraulic control was installed at each pasture outlet. The control is a three-inch Parshall flume. Each site will use a pressure transducer to measure stage and a CR-10 data recorder. Daily, monthly and annual surface-water runoff will be calculated at each pasture.
COOPERATOR:

Wisconsin Department of

Natural Resources

LOCATION

Sauk County

PROJECT CHIEF:

David J. Graczyk

PERIOD OF PROJECT:

October 1997 to September 2000

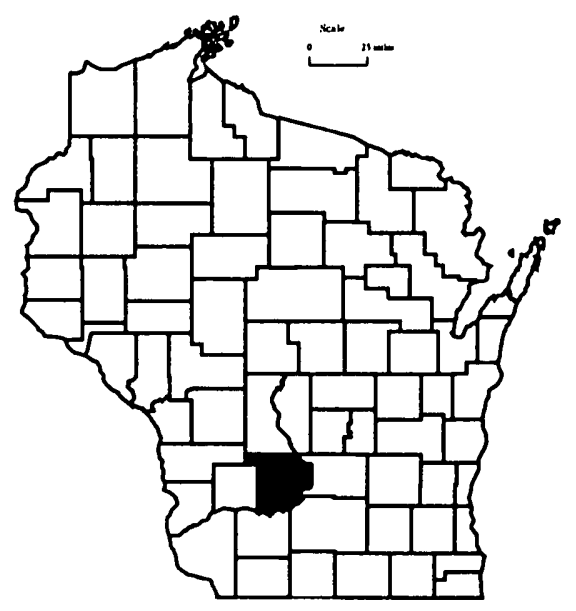


A tipping-bucket rain gage was installed at each site. Evapotranspiration will be estimated using empirical equations. Air temperature and solar radiation will be collected at one of the pastures for use in the evapotranspiration calculation. Meteorological data collected at the USDA Research Station will supplement data collected at this pasture. Ground-water flow will be calculated as a residual. An ISCO automatic water-quality sampler was installed at each site. The sampler will collect discrete samples. These samples will be composited on a flow-weighted basis. One composite sample per rainfall or snowmelt event will be sent to the Wisconsin State Laboratory of Hygiene for analysis. All events will be monitored. Approximately 5-10 samples per pasture will be collected. All samples will be analyzed for soluble reactive phosphorus, total phosphorus, ammonia nitrogen, nitrate and nitrite nitrogen, total kjeldahl nitrogen, total suspended solids, and volatile suspended solids.

PROGRESS (July 1999 to June 2000): Three small basins were monitored for continuous streamflow and rainfall. One runoff sample was collected at one site, five samples at another site and four runoff samples at the other site. Total-phosphorus concentrations ranged from $0.142 \mathrm{mg} / \mathrm{l}$ to $1.48 \mathrm{mg} / \mathrm{l}$ at the three sites. The storm loads for total phosphorus ranged from $0.003 \mathrm{lb}$ to $0.18 \mathrm{lb}$. The suspended-solids concentrations ranged from $5 \mathrm{mg} / 1$ to 1440 $\mathrm{mg} / \mathrm{l}$ at the three sites with suspended-solids loads ranging from $0.03 \mathrm{lb}$ to $116 \mathrm{lb}$. Samples of the runoff were a result of early winter rainfall and snowmelt events. No summer rainstorms or intense thunderstorms resulted in runoff. All data was summarized and published in the report "Water Resources Data-Wisconsin, 1999".

PLANS (July 2000 to June 2001): Monitoring at all three sites will be continued. Water-quality samples will be collected at the three sites for all storms that produce runoff and water-quality loads will be calculated for each storm. Animal grazing will be allowed according to the Managed Intensive Rotational Grazing Plan for each site. All streamflow and water-quality data will be summarized and published in the annual report "Water Resources Data-Wisconsin, 2000". 


\section{EVALUATION OF THE EFFECTIVENESS OF URBAN CONSERVATION DESIGN PRACTICES, WI 17233}

PROBLEM: Farmland in Wisconsin is rapidly being converted to urban land uses. This urban development, with the associated increase in impervious area, generally impacts the water quality and increases the runoff volume that is delivered to the receiving waterbody. When new site plans are proposed, many of the plans use "end-of-pipe" structural Best Management Practices (BMPs) such as wet and dry detention ponds. These structural BMPs, however, are primarily designed to reduce the flood peak of a runoff event. They have limited water-quality and -quantity benefits.

A non-structural type of BMP called urban stormwater-conservation design is being developed for urban land uses. This BMP involves reducing stormwater-runoff quantity and improving the stormwaterrunoff quality. These conservation designs include the reduction of impervious surfaces, redirection of downspouts to grassed areas, using grass infiltration swales and rain gardens to infiltrate runoff, and using cluster developments to encourage smaller lot sizes.

OBJECTIVE: The objective is to evaluate the effectiveness of urban conservation design for reducing runoff quantity and improving runoff water quality.

APPROACH: Two separate sites have been selected in Cross Plains, Wisconsin. The first site, which was developed from 1988 to 1991 , used traditional urban design practices such as storm sewers, curbs and gutters, and a wet detention basin. The second site, currently a farm field, will be developed in May 1999 using urban stormwater-conservation design practices. Both sites are finger valleys that are approximately a quarter mile apart.

Equipment at both sites will be installed and maintained to continuously monitor water level, precipitation, and water temperature. An automatic water-quality sampler will be installed at each site to take flow proportional samples. Water-quality samples for the majority of the runoff events will be analyzed for total and suspended solids, and total phosphorus. Periodically, samples from each site will be processed for particle-size distribution and selected total metals. All equipment at each site will be installed in a gaging station that will have phone telemetry and electrical power.

Comparisons will be made between the BMPs based on unit-area runoff and unit-area loads. Furthermore, the data collected during the seven-year period will document the changes in water quality and quantity during the construction cycle (from platting to site closeout).

PROGRESS (July 1999 to June 2000): Both sites were monitored during the subdivision platting phase and initial home construction was monitored at the rural site. A digital camera was installed to photodocument construction activities. These photos are displayed on the USGS web site.

PLANS (July 2000 to June 2001): Monitoring at both sites will continue. Additional monitoring equipment will be installed at the three pond inlets, the pond outlet and in the infiltration practice. Solids loads will be computed for all monitored runoff events at both sites.
COOPERATOR:

Wisconsin Department of

Natural Resources

\section{LOCATION:}

Cross Plains

\section{PROJECT CHIEF: David W. Owens}

PERIOD OF PROJECT: July 1998 to September 2005

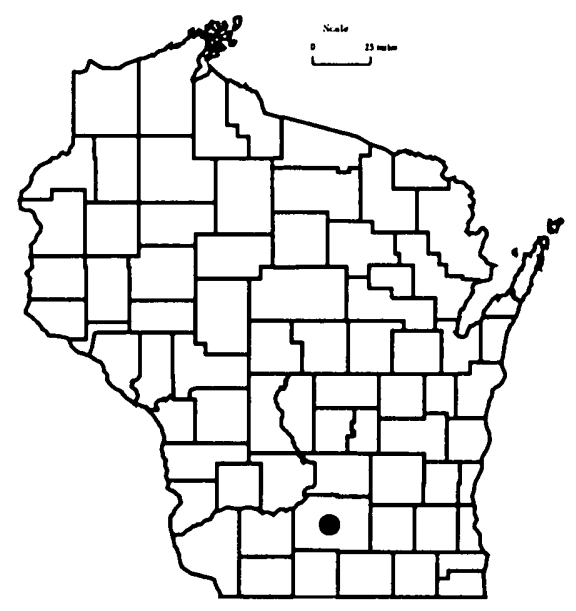




\section{TEMPERATURE MODELING OF URBAN STORMWATER RUNOFF, WI 17234}

\author{
COOPERATOR: \\ Wisconsin Department of \\ Natural Resources \\ LOCATION: \\ Cross Plains
}

PROJECT CHIEF:

David W. Owens

PERIOD OF PROJECT: July 1998 to September 2000
PROBLEM: Rainwater that falls on urban surfaces during the warm summer months tends to collect heat from those urban surfaces. The heated rainwater tends to drain quickly to storm sewers and then into streams or lakes. When the receiving water body is a cold water fishery, the thermal load can have a detrimental effect.

OBJECTIVE: The objective is to develop a model that can estimate the thermal heating of rainwater from urban surfaces during the summer months.

APPROACH: Sensors will be installed to monitor surface temperatures at a wide variety of thermal source areas in a drainage basin in Cross Plains, Wisconsin. These thermal source areas include roofs, streets, driveways and lawns. Furthermore, a variety of source area materials (asphalt, concrete, metal, etc.) and colors (light and dark) will also be monitored. The continuously collected data will document the changes in surface temperature and in the runoff water as the runoff water moves through the conveyance system. The data collected will be used to develop a model that will estimate the thermal impact of different urban surfaces.

PROGRESS (July 1999 to June 2000): Several sensors were installed and modified throughout the basin. Intensive data collection started in early June 1999 and continued until the end of September 1999. During this monitoring period, a worst-case thermal loading event did not occur. The equipment was activated in May 2000 to attempt to capture the worst-case thermal event. A water temperature model was developed to predict thermal loads to a coldwater-receiving stream based on the data collected during the summer of 1999 and 2000.

PLANS (July 2000 to September 2000): Additional temperature data will be collected until August 2000. New data collected will be used to calibrate the thermal runoff model. Model documentation will be completed during this time frame.

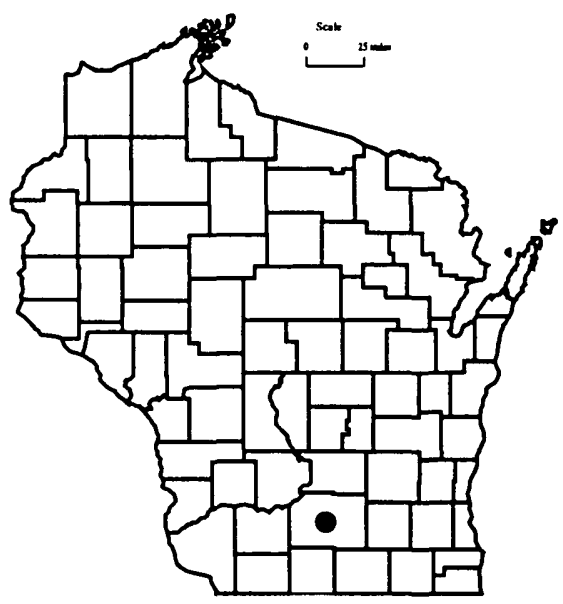




\section{ROCK RIVER PHOSPHORUS, WI 17236}

PROBLEM: Water quality of the Rock River depends on the load of nutrients contributed to the river by various sources. Sound management of water quality requires knowledge of the contributions of various sources to the total load of the river.

OBJECTIVE: The objective is to determine concentrations of various water-quality constituents at nine sites in the Rock River Ba$\sin$ in Wisconsin and to calculate loads for dissolved reactive phosphorus, total phosphorus and suspended solids

APPROACH: Water-quality samples will be collected by staff of the cooperating treatment works twice each month, and at additional times when there is significant runoff. These data will be used to compute loads of the following constituents until August 1999:

5-day Biological Oxygen Demand

Dissolved Chloride

Chlorophyll $a$

Fecal Coliform

Dissolved Ammonia

Nitrate + Nitrite

Dissolved Reactive Phosphorus

Total Dissolved Solids

Total Kjeldahl Nitrogen

Total Phosphorus

Suspended Solids

Volatile Suspended Solids

Data will be used to compute loads for the following constituents from September 1999 to August 2000:

5-day Biological Oxygen Demand

Nitrate + Nitrite

Total Phosphorus

Dissolved Reactive Phosphorus

Suspended Solids

Volatile Suspended Solids

PROGRESS (July 1999 to June 2000): Water-quality samples were collected and analyzed twice each month, with additional samples during significant runoff. Loads for three constituents were calculated for the period August 1998 through September 1999, and published in the annual data report. Sampling was continued for a second year, with the shortened list of constituents.

PLANS (July 2000 to September 2000): When a second full year of data has been collected (by the end of August 2000), the data will be used to compute loads of phosphorus and sediment. These will be published in the annual data report. A brief final report will be prepared explaining the data-collection procedures and summarizing the loads computed.
COOPERATORS:

City of Fort Atkinson

Rock River Watershed POTW

(66.30) Group

Wisconsin Department of

Natural Resources

LOCATION:

Rock River Basin

\section{PROJECT CHIEF:}

William R. Krug

PERIOD OF PROJECT: July 1998 to September 2000

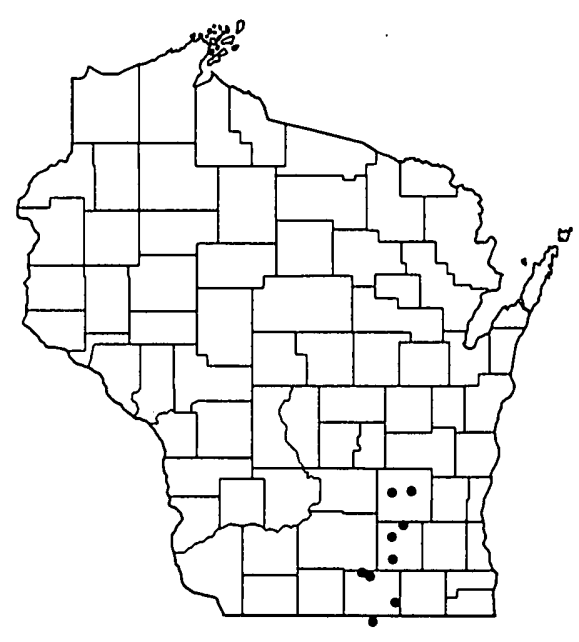




\section{TRACE METAL LOADING TO LAKES MICHIGAN AND SUPERIOR, WI 18301}

\author{
COOPERATOR: \\ Wisconsin Department of \\ Natural Resources \\ LOCATION: \\ United States portion of Lake \\ Michigan and Lake Superior \\ Basins
}

PROJECT CHIEF:

Dale M. Robertson

PERIOD OF PROJECT: October 1997-December 1999

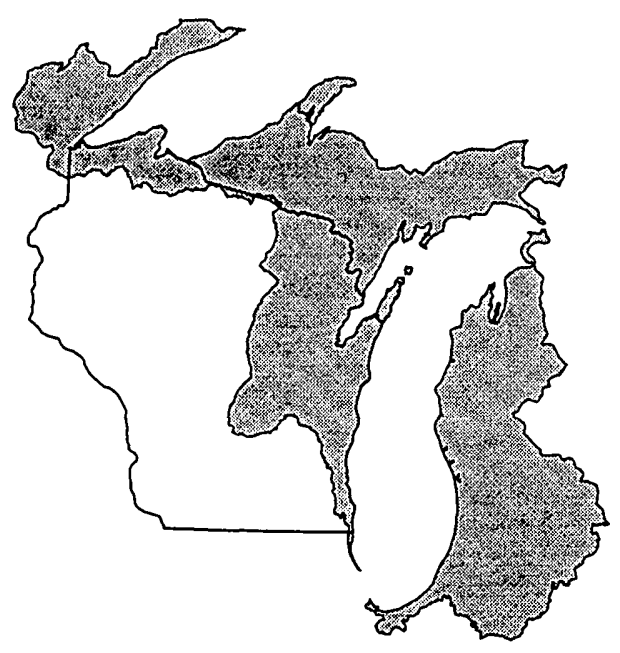

PROBLEM: The delivery of trace metals from point and nonpoint sources poses serious concerns for the coastal and offshore ecosystem of the Great Lakes. Though point-source loadings can be significant, evidence suggests that nonpoint-source contributions of metals exceed that of point sources. The tributary monitoring component of the Lake Michigan Mass Balance (LMMB) study will provide total loads of selected metals from the selected tributaries, but will not support source reconciliation.

OBJECTIVE: The objectives of this study are to (1) develop tributary load estimates of selected metal constituents to Lake Michigan and the U.S. portion of Lake Superior from both monitored and unmonitored watersheds, (2) describe what environmental factors influence the relative loading, and (3) separate the load into urban and nonurban components.

APPROACH: The approach used is as follows: (1) Develop GIS coverages of the environmental factors thought to influence the distribution of the selected metals; (2) subdivide the entire basin into areas of relatively homogeneous environmental characteristics; (3) sample sites representing areas that have not been previously sampled; (4) compute loads for selected metals for the main tributaries and daily loads (high flow and base flow) for smaller indicator streams from relatively homogeneous areas; (5) use GIS to determine environmental characteristics of main tributary basins and smaller indicator streams; (6) use multiple regression to relate loads from indicator sites to environmental characteristics; (7) use loads from smaller indicator areas with regression relations to estimate loading from ungaged areas and total regional loading; and (8) subtract the estimated watershed contribution from the total tributary load to estimate the urban inputs.

PROGRESS (July 1999 to June 2000): GIS data were obtained for land use, surficial deposits, and bedrock types for the complete Lake Michigan and U.S. part of the Lake Superior watershed. Multiple regression was used to relate copper, lead, mercury, and zinc loads from indicator sites to environmental characteristics. The loads from smaller indicator areas were used to determine which environmental variables were most strongly related to loading for each constituent and used to estimate loading from ungaged areas and total regional loading to Lakes Michigan and Superior. Localized urban inputs were estimated by subtracting the watershed contributions from the total tributary load from indicator areas. A final report was submitted to the Environmental Protection Agency.

PLANS: Project is completed. 


\section{TRANSPORT OF PCBS AT TWO SITES ON CEDAR CREEK, WI 19101}

PROBLEM: High concentrations of polychlorinated biphenyls (PCBs) have been found in the Cedar Creek bed sediments. water column, and fish tissues. Partial remediation (Ruck Impoundment) was completed in 1994. PCB transport trends are needed to assist in future management decisions.

OBJECTIVE: The objective is to determine PCB loading changes at Columbia Avenue (downstream of Ruck Impoundment) and Highland Road.

APPROACH: From August 1994 to August 1995, 24 PCB samples were collected at Columbia Avenue and Highland Road. Total suspended solids, chlorophyll $a$, and discharge data were used in conjunction with the PCB data to establish PCB concentration regression relations.

When sampling does begin, a total of 2480 -liter PCB samples (along supporting constituents) will be collected at the two Cedar Creek sites. Utilizing these data, residuals from the 1994/1995 regression relations will be examined to determine if PCB concentrations have changed over time.

PROGRESS (April 2000 to June 2000): Project planning has been completed and field sampling was planned to start in April 2000. Approval of a Quality Assurance Project Plan (QAPP) by EPA has been delayed and sampling will likely be delayed until the fall of 2000 .

PLANS (July 2000 to June 2001): Field operations will be continued.
COOPERATOR:

Wisconsin Department of

Natural Resources

LOCATION:

Calumet County .

PROJECT CHIEF:

Jeffrey J. Steuer

PERIOD OF PROJECT: April 2000 to September 2001

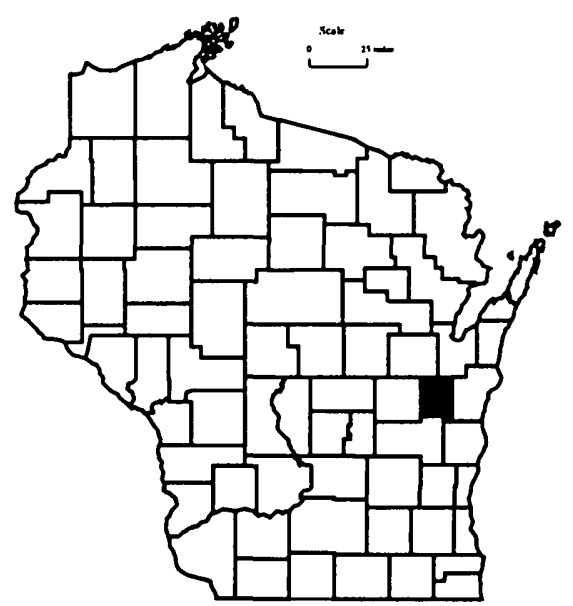




\section{MITIGATION OF FUTURE NORTH FORK URBANIZATION IMPACTS ON THE PHEASANT BRANCH HYDROLOGIC SYSTEM, WI 20200, 20202, 20203}

COOPERATOR:

City of Middleton

Wisconsin Department of

Natural Resources

LOCATION:

Dane County

PROJECT CHIEFS:

Jeffrey J. Steuer

Randy Hunt

PERIOD OF PROJECT:

July 1996 to September 2002

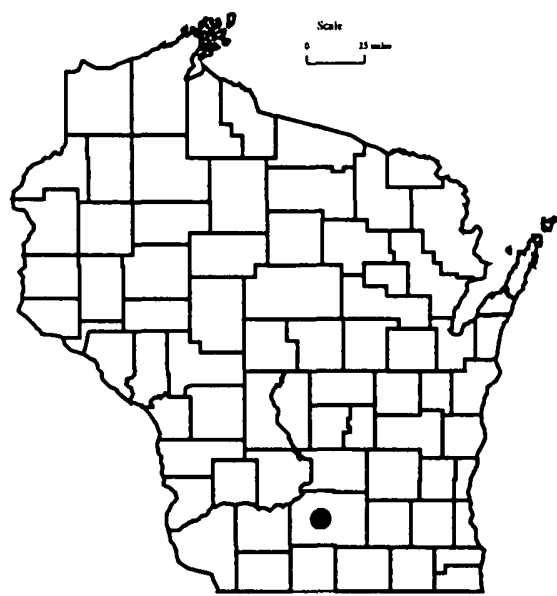

PROBLEM: As Middleton and its surroundings continue to develop, the Pheasant Branch North Fork Basin is expected to undergo significant urbanization. For the downstream city of Middleton, headwater urbanization can mean increased flood peaks, increased water volume and increased pollutant loads. It may also adversely effect down-gradient ecosystems such as Pheasant Branch Marsh and reduce ground-water recharge. Previous work has often not included the transient interaction between surface and ground water. The proposed work will combine ground- and surface-water modeling in the analysis of the Pheasant Branch system.

OBJECTIVE: Objectives are to (1) locate potential sites for runoff controls and/or enhanced infiltration to ensure future flood peaks do not exceed the present condition flood peaks, (2) quantify the flood peak and ground-water recharge differences resulting from a fully-urbanized condition with and without treatment or runoff controls, (3) use the ground-water model to assess North Fork basin urbanization impacts on Pheasant Branch Marsh, and (4) construct a ground-water model able to address future needs such as siting future water supply.

APPROACH: The overall approach will combine ground- and surface-water models to locate an effective combination of stormwater treatment or control sites within the North Fork basin which may be developed to produce minimal effects on the Pheasant Branch hydrologic system. The surface-water component will build upon the simulations detailed in "Effects of urbanization on streamflow, sediment loads, and channel morphology in Pheasant Branch Basin near Middleton, Wisconsin" (Krug and Goddard, 1985, WRIR 85-4068). To achieve the objectives of this project, the model will contain a spatial resolution to simulate 1 to 4 developments per square mile (approximately 40 model sub-areas). Significant development has occurred in the South Fork basin since 1981. Two of the areas simulated as not generating runoff in 1981 have developed and presently drain to the South Fork. It will be necessary to update the South Fork basin model to ensure that shifting of the North Fork hydrograph peak (due to runoff controls) will not produce an enhanced peak downstream of the confluence (Krug and Goddard, pages 16, 17). The new model efforts will calibrate to recently collected Pheasant Branch discharge and precipitation data collected at Highway 12. 
The ground-water component will use a model constructed at a smaller scale than the recently developed Dane County model (Krohelski, et.al., in press) to have the appropriate resolution for the stormwater control alternatives. Similar to Krohelski, et.al., the model will be constructed using MODFLOW (McDonald and Harbaugh, 1988). Recharge results from the surface-water model will be input into the ground-water-flow model to assess the effects of management alternatives on ground-water recharge distribution and magnitude. The model will also calculate the changes in groundwater-derived baseflow in the system for the different alternatives and assess the effectiveness of recharge enhancement scenarios.

In February 2000, the project was expanded when the models were accepted as part of an Environmental Protection Agency (EPA)National Science Foundation (NSF) research grant. The expanded research will be coordinated by the WDNR and UW-Madison. To further that effort, the surface-water model will be modified to incorporate research findings in local infiltration and temperature pollution. The ground-water model will be refined to include additional geologic data and hydrologic features near the Pheasant Branch Marsh. The refined model will then be used for optimization to further assess the effects of development on surface-water resources in the area.

PROGRESS (July 1999 to June 2000): Shallow well sites have been established in Pheasant Branch Marsh along with two continuous flow-monitoring and precipitation sites on the Pheasant Branch North and South Forks. Three additional rain gages have been added to the network. Double-ring infiltration tests (36) have been conducted with the results incorporated into the surface-water model. Discharge and water-quality loads (phosphorus and total suspended solids) have been published in the 1998 annual data report. Calibration is complete on a 50-flow plane, 21-hydrologicresponse unit model. Simulations have been conducted for moderate and heavy development scenarios.

Results from the initial modeling using the Dane County regional flow model showed that regional water (away from the immediate highlands) was needed to simulate measured spring flow. Porewaters within the wetland-creek complex were sampled for major ions and water isotopes. The fact sheet and supporting water-resources investigations reports (WRIRs) have been initiated.

Planning of work with the EPA-NSF research group began.

PLANS (July 2000 to June 2001): The fact sheet and supporting WRIRs will be completed. The calibrated surface-water model with the PRMS framework will be converted to the Modular Modeling System framework to allow incorporation of the infiltration and temperature pollution research. Additional physical and geochemical hydrologic data will be collected in the site area. The ground-water-flow model will be modified to include the insight gained from the new data. 


\section{DATABASE APPLICATIONS, WI 21000}

COOPERATOR:

City of Milwaukee

U.S. Environmental Protection

Agency

U.S. Geological Survey, CAPP and WRD

Wisconsin Department of Natural Resources (WDNR)

\section{LOCATION:}

United States

PROJECT CHIEF:

Harry House

PERIOD OF PROJECT:

July 1998-Continuing
PROBLEM: Natural resources agencies are having difficulty organizing, storing, and distributing their information products using existing resources (staff, hardware, and software).

OBJECTIVE: The purpose of this project is to provide our cooperators, the USGS, and other agencies with modern alternatives to their existing information technology resources. The objective is to provide customers with high-quality data processing methods.

APPROACH: The Database Unit in the Wisconsin District is dedicated to the design, development, and deployment of relational database systems geared to address water resources-related data management problems being faced by our cooperators and other federal agencies. Systems developed are centered on Oracle Corporation technology at this time. The focus is on fewer but larger projects in terms of workload and funding levels. The unit provides an alternative resource for these customers to compliment their inhouse information technology staff and/or outside consultants.

The unit attempts to apply cutting-edge technology in the resolution of the data management problems, within the limitations of available funding and staff. It is assumed that lower-end technology or approaches are more widely available to our customers already, and that we will provide a more valuable service by making higher-end solutions obtainable. The study has six subprojects.

PROGRESS (July 1999 to June 2000): For subproject 21005 , a series of meetings was held with the administrators of the 6 legacy databases and other data management personnel at WDNR to identify which WDNR data should be entered into the new database. Documentation for data in the 6 legacy systems was obtained and user requirements for the new system were discussed. A thirdnormal design for the new database has been completed, and reference tables are being populated. The WDNR Biology Database Project website has been created and a number of data input forms and reports are now mounted on the site. Data reporting capabilities include parameterized dynamic database query, customized reports, and downloading of data in an Excel format. When necessary, data are protected by passwords and assigned privileges.

PLANS (July 2000 to June 2001): For subproject 21005, the WDNR Biology Database will be initially sited at USGS offices in Middleton, Wisconsin, during testing and deployment, with plans to export the database to WDNR facilities in Madison, Wisconsin, in the near future. After reference tables are populated, forms will be prepared to enable input and retrieval of WDNR field data over the internet. It is expected that forms development will be an iterative process as user requirements are refined. As the database becomes populated with new data and also historical data, performance of the transactional database will be evaluated. If data reporting performance is inadequate, a system to deploy a denormalized version (star schema) and associated data-movement programming will be developed and implemented. 


\section{THE EFFECT OF NEAR-SHORE DEVELOPMENT ON CONSTITUENT LOADING TO LAKES IN NORTHERN WISCONSIN, WI 21800}

PROBLEM: Additions of nutrients, pesticides and sediment from near-shore developments to lakes may seriously degrade lake water quality. Shoreline-zoning regulations such as required setbacks, cutting restrictions and buffers between the lake and development have been developed in the hope that these requirements can mitigate the effects of sediment and nutrient runoff.

Previous studies have estimated the amount of these loadings from the lake watershed but few studies have determined the processes and pathways in which these constituents are delivered to the lake at a site-specific scale (e.g., one-acre parcel). The effectiveness of buffers or cutting restrictions on reducing the amount of chemical constituent loads and sediment has yet to be demonstrated.

OBJECTIVE: The objectives of the study are to (1) estimate the quantity of surface-water runoff and ground water that flows into a lake from developed and undeveloped lands and (2) determine the water quality of surface-water runoff and ground water that flows into a lake from developed and undeveloped lands.

APPROACH: Effects of shoreline development on water and nutrient loading will be assessed using a paired approach. The comparison will focus on developed and undeveloped sites on four lakes in Vilas and Forest Counties in northern Wisconsin. Developed sites may include runoff from lawns, driveways, sidewalks and roofs; undeveloped sites consist of mostly immature woods having woody and non-woody vegetation and relatively undistributed ground. Both surface-water runoff and ground-water components will be characterized where appropriate.

Sites were divided into those where the lakes have ground-water inflow and those that do not. Those that had ground-water inflow will be instrumented to characterize the ground- and surface-water components. Sites with ground-water flow away from the lake will be instrumented to characterize surface-water components only. Each site will be surveyed and a detailed map will be prepared to determine the areas that contribute to surface runoff.

A tipping bucket rain gage will be installed at each site. Precipitation will be measured during the non-freezing portion of the year. Precipitation from a nearby National Weather Service gage will be used during freezing periods.

Surface-water runoff will be measured by using two types of monitors depending on the site. An automatic collection monitor will be installed at four sites. A passive collection monitor will be installed at two sites. The quality of surface water will be determined from analyses of the runoff collected by both automated and non-automated systems.
COOPERATOR:

Wisconsin Department of Natural Resources

LOCATION:

Vilas and Forest Counties

PROJECT CHIEFS:

David J. Graczyk

Randall J. Hunt

PERIOD OF PROJECT: October 1999 to September 2001

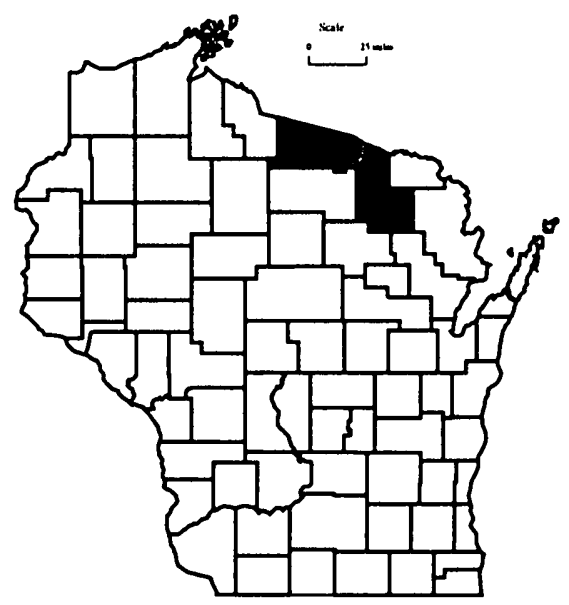


Ground-water flow will be monitored by the installation of piezometer nests. The nests will be distributed along the topographic gradient. The most down-gradient nest will be installed adjacent to the lakeshore. The quality of ground water will be determined from a subset of water table wells and piezometers located at the nest sites. In addition, the water quality of the ground water that discharge to the lake will be characterized using seepage meters and pore-water diffusion equilibrators.

All surface- and ground-water samples will be analyzed for total dissolved phosphorus, total phosphorus, ammonia nitrogen, nitrate and nitrite nitrogen and total Kjeldahl nitrogen. Approximately seven surface-water samples per site will be collected and 5-10 ground-water samples will be collected. The Wisconsin State Laboratory of Hygiene will analyze all samples.

PROGRESS (October 1999 to June 2000): Sites were selected for study and five automated surface-water runoff datacollection sites were installed. These sites include three lawn and two wood-land uses. Non-automated samplers at five woods and one lawn site were installed. Five ground-water data-collection systems were installed. Five tipping-bucket rain gages were also installed. Seven surface-water samples were collected. A detailed topographic map was prepared for each site.

PLANS (July 2000 to June 2001): Samples will be collected and analyzed at selected ground-water wells. Samples will be collected and analyzed at the surface-water data-collection sites. Seepage meters and pore-water equilibrators will be installed and waterquality samples will be collected. All water-quality data will be summarized and published in the annual report "Water Resources Data-Wisconsin, 2000". 


\section{APPENDIX A}

\section{STREAM-GAGING STATIONS PROPOSED FOR 2001 FISCAL YEAR}

PROBLEM: Surface-water information is needed for surveillance, planning, design, hazard warning, operation, and management in water-related fields such as water supply, hydroelectric power, flood control, irrigation, bridge and culvert design, wildlife management, pollution abatement, flood-plain management, and water-resources development. An appropriate data base is necessary to provide this information.

OBJECTIVE: The objectives of this project are to provide continuous-discharge records for selected rivers at specific sites to supply the need for regulation, analytical studies, definition of statistical properties, trends analysis, and determination of the occurrence and distribution of water in streams for planning. The project is also designed to determine lake levels and to provide discharge for flood and low-flow conditions and for water-quality investigations. Requests for streamflow data and information relating to streamflow in Wisconsin are answered. Basic data are published annually in the report "Water Resources Data-Wisconsin".

APPROACH: A network of streamflow-gaging stations and lake-level stations will be maintained throughout Wisconsin. This includes operating the equipment at the gaging station to record river or lake stage, making periodic discharge measurements at each streamflow station to establish or verify a stage-discharge rating curve, reducing the periodic stage readings to instantaneous and daily discharges, compilation of monthly and annual discharges, and preparing data for publication in the annual report, "Water Resources Data-Wisconsin".

Requests for streamflow data from other government agencies, consultants, and private parties will be processed.

PROGRESS (July 1999 to June 2000): Thirty-six continuous-record gaging stations were operated in cooperation with the Wisconsin Department of Natural Resources (WDNR) during the 2000 fiscal year. Twenty-four of these were funded through the Hydropower Data program and two were funded by other outside sources. Lake stage and precipitation data was collected on Devils Lake near Baraboo. Water temperature data was collected on the Prairie River and was funded by another source. More than 100 requests for streamflow data were answered; WDNR, other State, Federal, and county agencies, consultants, municipalities, and the general public requested data. Streamflow records for the 1999 water year were published in the annual report, "Water Resources Data-Wisconsin".

PLANS (July 2000 to June 2001): Streamflow records for the 2000 water year will be computed and published in the annual report, "Water Resources Data-Wisconsin". Present plans are to operate the same stations that were operated in the 2000 fiscal year except for the Fox River at Oshkosh station. The Detroit Corps of Engineers continued funding the operation of this station beginning January 1,2000. Requests for streamflow information will be answered.
COOPERATOR:

Wisconsin Department of Natural Resources

\section{LOCATION:}

Statewide

PROJECT CHIEF:

Barry K. Holmstrom

PERIOD OF PROJECT: July 1913-Continuing 


\section{PROPOSED PROGRAM FOR THE PERIOD 7/1/00-6/30/2001 \\ USGS Gaging Stations \\ Wisconsin Department of Natural Resources}

STREAMFLOW FOR HYDROPOWER DATA

04027500

04029990

04064500

04066003

04067958

04077400

05332500

05340500

05341500

05356000

05356500

05360500

05365500

05369000

05391000

05393500

05394500

05395000

05397500

05398000

05399500

05400760

05402000

05404000
1/ White River near Ashland

1/ Montreal River at Saxon Falls

2/ Pine River below Pine River powerplant near Florence 1924-76, 1996

2/ Menominee River near Pembine

5/ Peshtigo River near Wabeno

3/ Wolf River near Shawano -

1/ Namekagon River near Trego

1/ St. Croix River at St. Croix Falls

1/ Apple River near Somerset

1/ Chippewa River at Bishops Bridge near Winter

1/ Chippewa River near Bruce

1/ Flambeau River near Bruce

1/ Chippewa River at Chippewa Falls

1/ Red Cedar River at Menomonie

4/ Wisconsin River near Lake Tomahawk

4/ Spirit River at Spirit Falls

4/ Prairie River near Merrill

4/ Wisconsin River at Merrill

4/ Eau Claire River near Kelly

4/ Wisconsin River at Rothschild

4/ Big Eau Pleine River near Stratford

4/ Wisconsin River at Wisconsin Rapids

4/ Yellow River at Babcock

4/ Wisconsin River near Wisconsin Dells
Record began

(water year)

1948

1987

1950

1998

$1907-09,1911$

1928-70, 1987

1902

$1901-70,1987$

1912

1914

1951

1888-1983, 1987

1913

1936

1942

1914-31, 1939

1903

1914-27, 1939

1945

1914

1914

1944

1935

1/ WDNR cooperates with Northern States Power Company

2/ WDNR cooperates with Wisconsin Electric Power Company

3/ WDNR cooperates with Northwoods Hydropower

4/ WDNR cooperates with Wisconsin Valley Improvement Company

5/ WDNR cooperates with Wisconsin Public Service

Wisconsin Electric Power Company (WEPCO) funds two stations at a cost of $\$ 10,080$. Complete records are collected at nine stations and partial records at one station for the Wisconsin Valley Improvement Company (WVIC); total cost of the WVIC program is $\$ 47,880$. Partial records are collected at some of the Northern States Power Company stations; total cost of Northern States Power Company program is $\$ 38,680$. Northwoods Hydropower funds one station at a cost of $\$ 5,040$. Wisconsin Public Service funds one station at a cost of $\$ 5,040$.

\section{CONTINUOUS-RECORD MONITORING-RIVERS}

04024430 Nemadji River near South Superior

04067500 Menominee River near McAllister

04071765 Oconto River near Oconto

04085200 Kewaunee River near Kewaunee

04085395 South Branch Manitowoc River at Hayton

04085427 Manitowoc River at Manitowoc

04086000 Sheboygan River at Sheboygan

04086500 Cedar Creek near Cedarburg

05401050 Tenmile Creek near Nekoosa

05383075 LaCrosse River near LaCrosse

$$
\begin{gathered}
\text { Cost } \\
\$ 5,040 * \\
5,040 \\
5,040 \\
5,040 \\
5,040 \\
5,040 \\
5,040 \\
5,040 \\
5,040 \\
5,040
\end{gathered}
$$

$\$ 50,400$ 


\section{OTHER MONITORING}

05404500

Devil's Lake near Baraboo (stage-precipitation data) $\quad 1,950$

04084500

Fox River at Rapide Croche Dam near Wrightstown

2,100 (WDNR cooperates with Lower Fox River Dischargers' Association)

05394500

Prairie River near Merrill

650

Water-temperature monitoring

(WDNR cooperates with Friends of Prairie River)

TOTAL

$\$ 4,700$ 


\section{APPENDIX B \\ FUNDING SUMMARY PROPOSED FOR GENERAL COOPERATIVE PROGRAM WITH WISCONSIN DEPARTMENT OF NATURAL RESOURCES 2001 FISCAL YEAR}

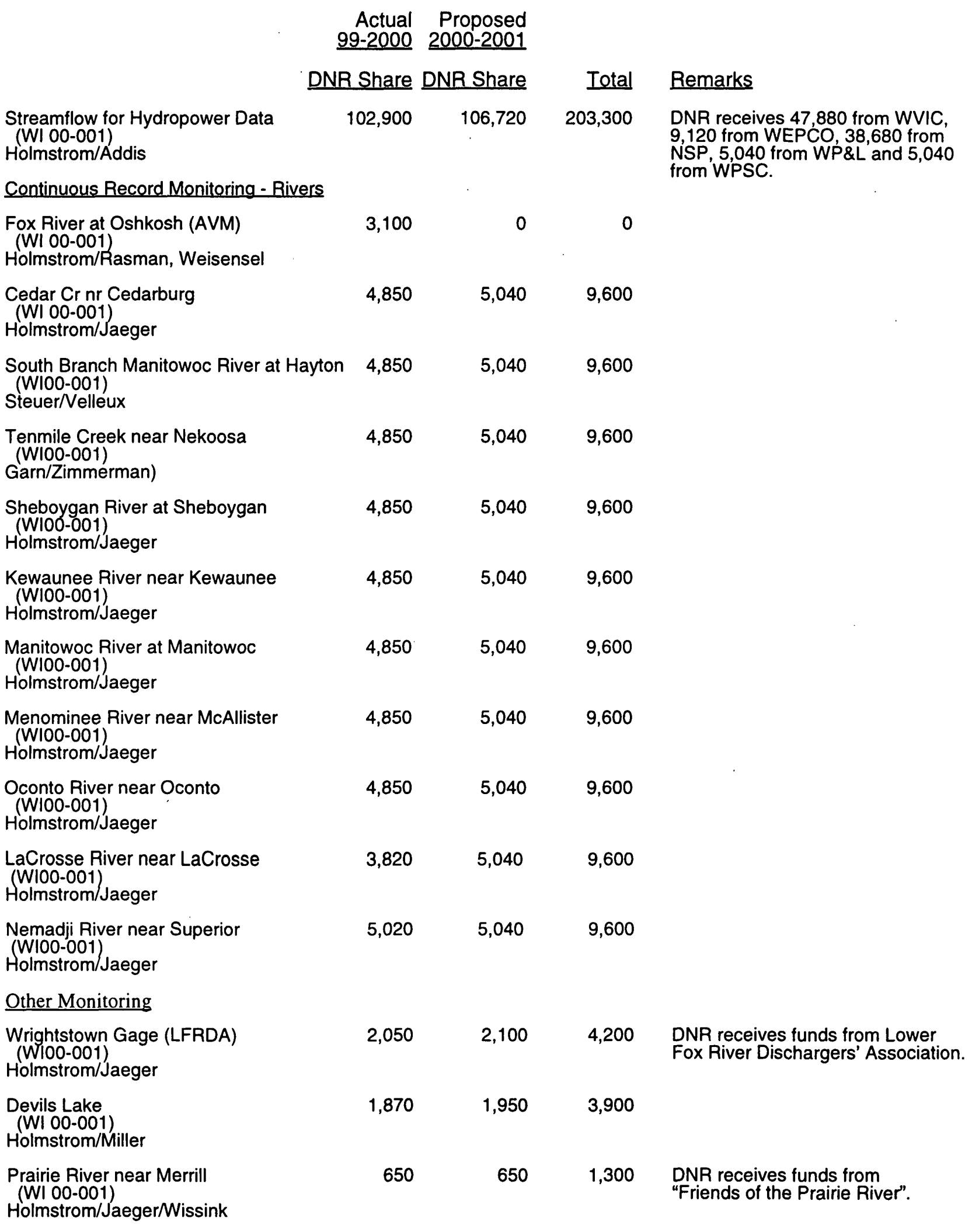




$\begin{array}{rcrl}\begin{array}{r}\text { Actual } \\ 99-2000\end{array} & \begin{array}{r}\text { Proposed } \\ \text { 2000-2001 }\end{array} \\ \text { DNR Share } & \frac{\text { DNR Share }}{2,925} & 0 & \frac{\text { Total }}{\text { Remarks }}\end{array}$

Rock River @ Hustisford (WI 17317)

Garn/Congdon

Dead Pike Lake

$\begin{array}{lll}0 & 16,800 \quad 28,000\end{array}$ 


\begin{tabular}{|c|c|c|c|c|}
\hline & $\begin{array}{r}\text { Actual } \\
99-2000 \\
\end{array}$ & $\begin{array}{r}\text { Proposed } \\
2000-2001 \\
\end{array}$ & & \\
\hline$\underline{\mathrm{DN}}$ & NR Share & DNR Share & Total & Remarks \\
\hline $\begin{array}{l}\text { Crandon } \\
(\text { WI 00-201) } \\
\text { Krohelski/Tans }\end{array}$ & 350,000 & 50,000 & 50,000 & \\
\hline $\begin{array}{l}\text { Water-Use Data } \\
\text { (WI 78-007) } \\
\text { Ellefson/Baker }\end{array}$ & 75,000 & 75,000 & 150,000 & 75,000 direct state services. \\
\hline $\begin{array}{l}\text { Nonpoint Trends } \\
\text { (Wl 91-172) } \\
\text { Hughes/Bannerman } \\
17202 \text { - Bower/Otter } \\
17204 \text { - Eagle/Joos } \\
17206 \text { - Evaluation BMP } \\
17213 \text { - GlS Data Base } \\
17214 \text { - Single-Source Site } \\
17223 \text { - Multi-Stream Exp. Design } \\
17233 \text { - Urban Conservancy Design } \\
17220 \text { - Ruby Street Report Milwaukee }\end{array}$ & $\begin{array}{r}18,200 \\
22,200 \\
32,200 \\
59,400 \\
69,200 \\
54,900 \\
30,100 \\
1,500\end{array}$ & & & 2000-2001 under discussion. \\
\hline $\begin{array}{l}\text { Rotational Grazing } \\
\text { (WI 17229) } \\
\text { Hughes/Greb }\end{array}$ & 13,700 & 13,700 & 26,000 & \\
\hline $\begin{array}{l}\text { Regional Trace Metal } \\
\text { (Wi 18301) } \\
\text { Robertson/Hurley }\end{array}$ & 3,000 & 0 & 0 & \\
\hline $\begin{array}{l}\text { Temperature Modeling } \\
\text { (W1 17234) } \\
\text { Owens/Greb }\end{array}$ & 16,000 & 0 & 0 & \\
\hline $\begin{array}{l}\text { Fox River } \\
\text { (WI 14500) } \\
\text { Steuer/Paulson }\end{array}$ & 442,050 & & & 2000-2001 under discussion. \\
\hline $\begin{array}{l}\text { LaCrosse Brownfield } \\
\text { (WI 00204) } \\
\text { Saad/Brumberg, Amerson }\end{array}$ & 10,470 & 0 & 0 & \\
\hline $\begin{array}{l}\text { Prototype Database System } \\
\text { (WI-21000) } \\
\text { Hall, House/Staggs, Emmons }\end{array}$ & 125,000 & 125,000 & 125,000 & \\
\hline $\begin{array}{l}\text { Riparian Vegetative Zones } \\
(\text { Wl-21800) } \\
\text { Graczyk, Hunt/Knauer, Greb }\end{array}$ & 64,200 & 43,200 & 72,000 & \\
\hline $\begin{array}{l}\text { Cedar Creek PCB } \\
\text { (WI-19100) } \\
\text { Steuer, Westebrook }\end{array}$ & 26,000 & 0 & 0 & \\
\hline $\begin{array}{l}\text { Mercury Loons } \\
\text { (WI-19701) } \\
\text { KrabbenhoftMeyer, Knauer }\end{array}$ & 20,000 & 0 & 0 & \\
\hline $\begin{array}{l}\text { Fish Creek Vanes } \\
\text { (Wl-19300) } \\
\text { FitzpatrickWalls }\end{array}$ & 0 & 26,340 & 43,900 & \\
\hline $\begin{array}{l}\text { Urban Filtration BMP } \\
\text { (WI-17208) } \\
\text { Corsi/Bannerman }\end{array}$ & 0 & 51,000 & 81,300 & \\
\hline $\begin{array}{l}\text { Rock River Phosphorus } \\
\text { (Wl-17236) } \\
\text { Krug/Johnson }\end{array}$ & 13,000 & 0 & 0 & \\
\hline
\end{tabular}




\section{WISCONSIN DISTRICT PUBLICATIONS}

The reports listed below are a partial list of reports prepared by the Wisconsin District in cooperation with other agencies since 1948. The list contains reports that are relevant and contribute significantly to understanding the hydrology of Wisconsin's water resources.

The reports published in a U.S. Geological Survey series are for sale by the U.S. Geological Survey, Box 25286, Federal Center, Denver, CO 80225. Prepayment is required. Remittance should be sent by check or money order payable to the U.S. Geological Survey. Prices can be obtained by writing to the above address or by calling 1-888-ASK-USGS. Copies of reports published by the University of Wisconsin, Geological and Natural History Survey, can be obtained from their office at 3817 Mineral Point Road, Madison, WI 53705.

\section{WATER-SUPPLY PAPERS}

Kammerer, P.A., Jr., and Krug, W.R., 1993, Wisconsin stream water quality, in U.S. Geological Survey, National water summary 1990-91-Hydrologic events and stream water quality: U.S. Geological Survey Water-Supply Paper 2400, p. 561-568.

Melcher, N.B., and Walker, J.F., 1992, Evaluation of selected methods for determining streamflow during periods of ice effect: U.S. Geological Survey Water-Supply Paper 2378, 47 p.

U.S. Geological Survey, 1991, National water summary 1988-89Hydrologic Events and Floods and Droughts: U.S. Geological Survey Water-Supply Paper 2375, $591 \mathrm{p}$.

U.S. Geological Survey, 1990, National water summary 1987Hydrologic events and water supply and use: U.S. Geological Survey Water-Supply Paper 2350, $553 \mathrm{p}$.

1988, National water summary 1986-Hydrologic events, selected water-quality trends, and ground-water quality: U.S. Geological Survey Water-Supply Paper 2325, 569 p.

1986, National water summary 1985-Hydrologic events and surface-water resources: U.S. Geological Survey Water-Supply Paper 2300, $506 \mathrm{p}$.

1985. National water summary 1984-Hydrologic events, selected water-quality trends, and ground-water resources: U.S. Geological Survey Water-Supply Paper 2275, 467 p.

1984, National water summary 1983-Hydrologic events and issues: U.S. Geological Survey Water-Supply Paper 2250, 243 p.

Batten, W.G., and Hindall, S.M., 1980, Sediment deposition in the White River Reservoir, northwestern Wisconsin: U.S. Geological Survey Water-Supply Paper 2069, 30 p.

Sherrill, M.G., 1978, Geology and ground water in Door County, Wisconsin, with emphasis on contamination potential in the Silurian dolomite: U.S. Geological Survey Water-Supply Paper 2047, 38 p.

Hurtgen, D.C., 1975, Summary of floods, June 29-30 in southwestern Wisconsin, in Summary of floods in the United States during 1969: U.S. Geological Survey Water-Supply Paper 2030, p. 116 119.

Bell, E.A., and Sherrill, M.G., 1974, Water availability in central Wisconsin-an area of near-surface crystalline rock: U.S. Geological Survey Water-Supply Paper 2022, 32 p.

Novitzki, R.P., 1973, Improvement of trout streams in Wisconsin by augmenting low flows with ground water: U.S. Geological Survey Water-Supply Paper 2017, 52 p.
Oakes, Edward, Field, S.J., and Seeger, L.P., 1973, The Pine-Popple River basins-hydrology of a wild river area, northeastern Wisconsin: U.S. Geological Survey Water-Supply Paper 2006, $57 \mathrm{p}$.

Hamilton, L.J., 1971, Water for cranberry culture in the Cranmoor area of central Wisconsin: U.S. Geological Survey Water-Supply Paper 1999-I, 20 p.

Hurtgen, D.C., 1972, Floods of March 27-April 4, 1967, in northwestern and west-central Wisconsin, in summary of floods in the United States during 1967: U.S. Geological Survey WaterSupply Paper 1880-C, p. 7-10.

Hutchinson, R.D., 1970, Ground-water resources of Racine and Kenosha Counties, Wisconsin: U.S. Geological Survey WaterSupply Paper 1878, 63 p.

Olcott, P.G., 1966, Geology and water resources of Winnebago County, Wisconsin: U.S. Geological Survey Water-Supply Paper $1814,61 \mathrm{p}$.

Weeks, E.P., Erickson, D.W., and Holt, C.L.R., Jr., 1965, Hydrology of the Little Plover River basin, Portage County, Wisconsin, and the effects of water-resources development: U.S. Geological Survey Water-Supply Paper $1811,78 \mathrm{p}$.

Green, J.H., and Hutchinson, R.D., 1965, Ground-water pumpage and water-level changes in the Milwaukee-Waukesha area, Wisconsin, 1950-61: U.S. Geological Survey Water-Supply Paper 1809-I, $19 \mathrm{p}$.

Summers, W.K., 1965, Geology and ground-water resources of Waushara County, Wisconsin: U.S. Geological Survey WaterSupply Paper 1809-B, 32 p.

Holt, C.L.R., Jr., and Knowles, D.B., 1963, The water situation in Wisconsin in the role of ground water in the national water situation: U.S. Geological Survey Water-Supply Paper 1800, p. 943 960.

Cline, D.R., 1965, Geology and ground-water resources of Dane County, Wisconsin: U.S. Geological Survey Water-Supply Paper 1779-U, $64 \mathrm{p}$.

Holt, C.L.R., Jr., 1965, Geology and water resources of Portage County, Wisconsin: U.S. Geological Survey Water-Supply Paper 1796, $77 \mathrm{p}$.

Berkstresser, C.F., Jr., 1964, Ground-water resources of Waupaca County, Wisconsin: U.S. Geological Survey Water-Supply Paper 1669-U, 38 p.

Knowles, D.B., 1964, Ground-water conditions in the Green Bay area, Wisconsin, 1950-60: U.S. Geological Survey Water-Supply Paper 1669-J, $37 \mathrm{p}$. 
Cline, D.R., 1963, Hydrology of upper Black Earth Creek basin, Wisconsin, with a section on surface water by M.W. Busby: U.S. Geological Survey Water-Supply Paper 1669-C, 27 p.

Collier, C.R., 1963, Sediment characteristics of small streams in southern Wisconsin, 1954-59: U.S. Geological Survey WaterSupply Paper 1669-B, 34 p.

LeRoux, E.F., 1963, Geology and ground-water resources of Rock County, Wisconsin: U.S. Geological Survey Water-Supply Paper 1619-X, $50 \mathrm{p}$.

Newport, T.G., 1962, Geology and ground-water resources of Fond du Lac County, Wisconsin: U.S. Geological Survey Water-Supply Paper 1604, $52 \mathrm{p}$.

Knowles, D.B., Dreher, F.C., and Whetstone, G.W.,- 1964, Water resources of the Green Bay area, Wisconsin: U.S. Geological Survey Water-Supply Paper 1499-G, 66 p.

LeRoux, E.F., 1957, Geology and ground-water resources of Outagamie County, Wisconsin: U.S. Geological Survey WaterSupply Paper 1421, $57 \mathrm{p}$.

Harger, A.H., and Drescher, W.J., 1954, Ground-water conditions in south-western Langlade County, Wisconsin: U.S. Geological Survey Water-Supply Paper 1294, 39 p.

Foley, F.C., Walton, W.D., and Drescher, W.J., 1953, Ground-water conditions in the Milwaukee-Waukesha area, Wisconsin: U.S. Geological Survey Water-Supply Paper 1229, 96 p.

\section{HYDROLOGIC INVESTIGATIONS ATLASES}

Kammerer, Phil A., Jr., Trotta, Lee C., Krabbenhoft, David P., and Lidwin, R.A., 1998, Geology, ground-water flow, and dissolved-solids concentrations in ground water along hydrogeologic sections through Wisconsin aquifers, U.S. Geological Survey Hydrologic Investigations Atlas, HA-731, 4 sheets.

Gebert, W.A., Graczyk, D.J., and Krug, W.R., 1987, Average annual runoff in the United States, 1951-80: U. S. Geological Survey Hydrologic Investigations Atlas HA-710, 1 sheet.

Hughes, P.E., Hannuksela, J. S., and Danchuk, W.J., 1981, Flood of July 1-5, 1978, on the Kickapoo River, South-western Wisconsin: U.S. Geological Survey Hydrologic Investigations Atlas HA653,7 sheets.

Oakes, E.L., and Cotter, R.D., 1975, Water resources of Wisconsinupper Wisconsin River basin: U.S. Geological Survey Hydrologic Investigations Atlas HA-536, 3 sheets.

Young, H.L., and Skinner, E.L., 1974, Water resources of WisconsinLake Superior basin: U.S. Geological Survey Hydrologic Investigations Atlas HA-524, 3 sheets.

Hindall, S.M., and Borman, R.G., 1974, Water resources of Wisconsin-lower Wisconsin River basin: U.S. Geological Survey Hydrologic Investigations Atlas HA-479, 3 sheets.

Young, H.L., and Borman, R.D., 1973, Water resources of Wisconsin-Trempealeau-Black River basin: U.S. Geological Survey Hydrologic Investigations Atlas HA-474, 4 sheets.

Oakes, E.L., and Hamilton, L.J., 1973, Water resources of Wisconsin-Menominee-Oconto-Peshtigo River basin, U.S. Geological Survey Hydrologic Investigations Atlas HA-470, 4 sheets.

Hindall, S.M., and Skinner, E.L., 1973, Water resources of Wisconsin-Pecatonica-Sugar River basin: U.S. Geological Survey Hydrologic Investigations Atlas HA-453, 3 sheets.
Young, H.L., and Hindall, S.M., 1973, Water resources of Wisconsin-St. Croix River basin: U.S. Geological Survey Hydrologic Investigations Atlas HA-451, 4 sheets.

Skinner, E.L., and Borman, R.G., 1973, Water resources of Wisconsin-Lake Michigan basin: U.S. Geological Survey Hydrologic Investigations Atlas HA-432, 4 sheets.

Shearman, J.O., and Holmstrom, B.K., 1971, Floods on Rock River in southwestern Jefferson County, Wisconsin: U.S. Geological Survey Hydrologic Investigations Atlas HA-413, 1 sheet.

1971, Floods on Rock River in northeastern Jefferson County, Wisconsin: U.S. Geological Survey Hydrologic Investigations Atlas HA-394, 1 sheet.

Sherman, J.O., 1970, Floods on Rock River in northem Rock County, Wisconsin: U.S. Geological Survey Hydrologic Investigations Atlas HA-393, 1 sheet.

Gebert, W.A., 1971, Low-flow frequency of Wisconsin streans: U.S. Geological Survey Hydrologic Investigations Atlas HA- 390, 1 sheet.

Young, H.L., and Hindall, S.M., 1972, Water resources of Wisconsin-Chippewa River basin: U.S. Geological Survey Hydrologic Investigations Atlas HA-386, 4 sheets.

Hindall, S.M., and Flint, R.F., 1970, Sediment yields of Wisconsin streams: U.S. Geological Survey Hydrologic Investigations Atlas HA-376, 1 sheet.

Devaul, R.W., and Green, J.H., 1971, Water resources of Wisconsincentral Wisconsin River basin: U.S. Geological Survey Hydrologic Investigations Atlas HA-367, 4 sheets.

Cotter, R.D., Hutchinson, R.D., Skinner, E.L., and Wentz, D.A., 1969, Water resources of Wisconsin-Rock-Fox River basin: U.S Geological Survey Hydrologic Investigations Atlas HA-360. 4 sheets.

Olcott, P.G., 1968, Water resources of Wisconsin-Fox-Wolf River basin: U.S. Geological Survey Hydrologic Investigations Atlas HA-321, 4 sheets.

U.S. Geological Survey, 1965, Preliminary map of the conterminous United States showing depth to and quality of shallowest ground water containing more than 1,000 parts per million dissolved solids: U.S. Geological Survey Hydrologic Investigations Atlas HA-199, 31 p., 2 sheets.

\section{PROFESSIONAL PAPERS}

Young, H.L., 1992, Summary of ground-water hydrology of the Cambrian-Ordovician aquifer system in the northern midwest, United States: U.S. Geological Survey Professional Paper 1405-A, 55 p.

1992. Hydrogeology of the Cambrian-Ordovician aquifer system in the northern midwest, United States: U.S. Geological Survey Professional Paper 1405-B, 99 p., 1 pl.

Mandle, R.J., and Kontis, A.L., 1992, Simulation of regional groundwater flow in the Cambrian-Ordovician aquifer system in the northern midwest, United States: U.S. Geological Survey Professional Paper 1405-C, $97 \mathrm{p}$.

Siegel, D.I., 1989, Geochemistry of the Cambrian-Ordovician aquifer system in the northern midwest, United States: U.S. Geological Survey Professional Paper 1405-D, 76 p.

Green, J.H., 1968, The Troy Valley of southeastern Wisconsin: U.S. Geological Survey Professional Paper 600-C, p. 135-139. 
Carey, K.L., 1967, The underside of river ice, St. Croix River, Wisconsin: U.S. Geological Survey Professional Paper 575-C, p. 195-199.

1966, Observed configuration and computed roughness of the underside of river ice, St. Croix River, Wisconsin: U.S. Geological Survey Professional Paper 550-B, p. 192-198.

Weeks, E.P., 1964, Field methods for determining vertical permeability and aquifer anisotropy: U.S. Geological Survey Professional Paper 501-D, p. 193-198.

1964, Use of water-level recession curves to determine the hydraulic properties of glacial outwash in Portage County, Wisconsin: U.S. Geological Survey Professional Paper 501-B, p. 181-184.

\section{WATER-RESOURCES INVESTIGATIONS REPORTS}

Grannemann, N.G., Hunt, R.J., Nicholas, J.R., Reilly, T.E., and Winter, T.C., 2000, The importance of ground water in the Great Lakes Region: U.S. Geological Survey Water-Resources Investigations Report 00-4008, 14 p.

Brown, Timothy A., Dunning, Charles P., and Sharpe, Jennifer B., 2000, Altitude, depth, and thickness of the Galena-Platteville bedrock unit in the subcrop area of Illinois and Wisconsin: U.S. Geological Survey Water-Resources Investigations Report 97 4054-C, 4 sheets.

Lenz, Bernard N. and Rheaume, S.J., Benthic invertebrates of fixed sites in the Western Lake Michigan Drainages, Wisconsin and Michigan, 1993-95: U.S. Geological Survey Water-Resources Investigations Report 95-4211-D, 30 p.

Krohelski, J.T., Feinstein, D.T., and Lenz, B.N., 1999, Simulation of stage and hydrologic budget for Shell Lake, Washburn County, Wisconsin: U.S. Geological Survey Water-Resources Investigations Report 99-4209, 23 p.

Batten, W.G., Yeskis, D.J., and Dunning, C.P., 1999, Hydrogeologic properties of the Ordovician Sinnipee Group at test well BN483, better brite superfund site, De Pere, Wisconsin: U.S. Geological Survey Water-Resources Investigations Report 99$4199,19 \mathrm{p}$.

Waschbusch, R.J., 1999, Evaluation of the effectiveness of an urban stormwater treatment unit in Madison, Wisconsin, 1996-97: U.S. Geological Survey Water-Resources Investigations Report 99 4195, $49 \mathrm{p}$.

Steuer, Jeffrey S., Hall, David W., and Fitzgerald, Sharon A., 1999, Distribution and transport of polychlorinated biphenyls and associated particulates in the Hayton Millpond, South Branch Manitowoc River, 1993-95: U.S. Geological Survey Water-Resources Investigations Report 99-4101, 20 p.

Steuer, Jeffrey S., Fitzgerald, Sharon A., and Hall, David, 1999, Distribution and transport of polychlorinated biphenyls and associated particulates in the Milwaukee River system, Wisconsin, 1993-95: U.S. Geological Survey Water-Resources Investigations Report 99-4100, $37 \mathrm{p}$.

Fitzpatrick, Faith A., Knox, James C., and Whitman, Heather E., 1999, Effects of historical land-cover changes on flooding and sedimentation, North Fish Creek, Wisconsin: U.S. Geological Survey Water-Resources Investigations Report 99-4083, 12 p.

Waschbusch, R.J., Selbig, W.R., and Bannerman, R.T., 1999, Sources of phosphorus from two urban residential basins in Madison, Wisconsin, 1994-95, U.S. Geological Survey Water-Resources Investigations Report 99-4021, 47 p.
Saad, David A., and Schmidt, Morgan A., 1999, Water-resources-related information for the Oneida Reservation and vicinity, Wisconsin, U.S. Geological Survey Water-Resources Investigations Report 98-4266, 57 p.

Saad, David A., and Thorstenson, Donald C., 1998, Flow and geochemistry along shallow ground-water flowpaths in an agricultural area in southeastern Wisconsin: U.S. Geological Survey Water-Resources Investigations Report 98-4179, $62 \mathrm{p}$.

Robertson, Dale M., 1998, Evaluation of the surface-water sampling design in the Western Lake Michigan Drainages in relation to environmental factors affecting water quality at base flow, U.S. Geological Survey Water-Resources Investigations Report 98-4072, 53 p.

Walker, John F., Saad, David A., and Krohelski, James T., 1998, Optimization of ground-water withdrawal in the lower Fox River communities, Wisconsin: U.S. Geological Survey WaterResources Investigations Report 97-4218, 24 p.

Richards, Kevin D., Sullivan, Daniel J., and Stewart, Jana S., 1998, Surface-water quality at fixed sites in the Western Lake Michigan Drainages, Wisconsin and Michigan, and the effects of natural and human factors, 1993-95, U.S. Geological Survey Water-Resources Investigations Report 97-4208, 40 p.

Stewart, Jana S., 1998, Combining satellite data with ancillary data to produce a refined land-use/land-cover map: U.S. Geological Survey Water-Resources Investigations Report 97-4203, 11 p., 3 pl.

Conlon, T.D., 1998, Hydrogeology and simulation of ground-water flow in the sandstone aquifer, northeastem Wisconsin: U.S. Geological Survey Water-Resources Investigations Report 97-4096, $60 \mathrm{p} ., 1 \mathrm{pl}$.

Elder, John F., Manion, Bart J., and Goddard, Gerald L., 1997, Mesocosm experiments to assess factors affecting phosphorus retention and release in an extended Wisconsin wetland: U.S. Geological Survey Water-Resources Investigations Report 97 $4272,14 \mathrm{p}$

Steuer, Jeffrey, Selbig, William, Homewer, Nancy, and Prey, Jeffrey, 1997, Sources of contamination in an urban basin in Marquette, Michigan and an analysis of concentrations, loads, and data quality: U.S. Geological Survey Water-Resources Investigations Report $97-4242,25 \mathrm{p}$.

Peters, Charles A., et al, 1997, Environmental setting and implications for water quality in the Western Lake Michigan drainage: U.S. Geological Survey Water-Resources Investigations Report 974196, $79 \mathrm{p}$.

Scudder, Barbara C., Sullivan, Daniel J., Fitzpatrick, Faith A., and Rheaume, Stephen J., 1997, Trace elements and synthetic organic compounds in biota and streambed sediment of the Western Lake Michigan drainages, 1992-1995: U.S. Geological Survey WaterResources Investigations Report 97-4192, 34 p.

Fitzgerald, Sharon A., 1997, Results of quality-control sampling of water, bed sediment, and tissue in the Western Lake Michigan drainages study unit of the national water-quality assessment program: U.S. Geological Survey Water-Resources Investigations Report 97-4148, 24 p.

Batten, W.G., Brown, T.A., Mills, P.C., and Sabin, T.J., 1997, Rockstratigraphic nomenclature, lithology, and subcrop area of the Galena-Platteville bedrock unit in Illinois and Wisconsin: U.S. Geological Survey Water Resources Investigations Report 97. 4054-B, 1 sheet.

Sullivan, Daniel J. and Peterson, Elise M., 1997, Fish communities of benchmark streams in agricultural areas of eastern Wisconsin: Water Resources Investigations Report 96-4038-D, 23 p. 
Sullivan, Daniel J., 1997, Fish communities of fixed sites in the Western Lake Michigan drainages, Wisconsin and Michigan, 1993-95: U.S. Geological Survey Water-Resources Investigations Report 95-4211-C, 23 p.

Fitzpatrick, Faith A., and Giddings, Elise M.P., 1997, Stream habitat characteristics of fixed sites in the Western Lake Michigan drainages, Wisconsin and Michigan, 1993-95: U.S. Geological Survey Water-Resources Investigations Report 95-4211-B, 58 p.

Garn, Herbert S., Olson, Daniel L., Seidel, Tracy L., and Rose, William J., 1996, Hydrology and water quality of Lauderdale Lakes, Walworth County, Wisconsin, 1993-94: U.S. Geological Survey Water-Resources Investigations Report 96-4235, 29 p.

Conlon, T.D., 1996, Hydrogeology of the sand and gravel aquifer in the vicinity of the Wild Rose State Fish Hatchery, North-Central Waushara County, Wisconsin: U.S. Geological Survey WaterResources Investigations Report 96-4213, 14 p.

Legg, Andrew D., Bannerman, Roger T., and Panuska, John, 1996, Variation in the relation of rainfall to runoff from residential lawns in Madison, Wisconsin, July and August 1995: U.S. Geological Survey Water-Resources Investigations Report 96-4194, $11 \mathrm{p}$.

Robertson, Dale M., Field, Stephen J., Elder, John F., Goddard, Gerald L., and James, William F., 1996, Phosphorus dynamics in Delavan Lake Inlet, Southeastern Wisconsin, 1994: U.S. Geological Survey Water-Resources Investigations Report 96-4160, $18 \mathrm{p}$.

Robertson, Dale M., 1996, Use of frequency-volume analyses to estimate regionalized yields and load of sediment, phosphorus, and polychlorinated biphenyls to Lakes Michigan and Superior: U.S. Geological Survey Water-Resources Investigations Report 96$4092,47 \mathrm{p}$.

Fitzpatrick, Faith A., Peterson, Elise M., and Stewart, Jana S., 1996, Habitat characteristics of benchmark streams in agricultural areas of Eastern Wisconsin: U.S. Geological Survey Water-Resources Investigations Report 96-4038-B, $35 \mathrm{p}$.

Rheaume, S.J., Stewart, J.S., and Lenz, Bernard N., 1996, Environmental setting of benchmark streams in agricultural areas of Eastern Wisconsin: U.S. Geological Survey Water-Resources Investigations Report 96-4038-A, 50 p.

Robertson, Dale M., and Saad, David A., 1996, Water-quality assessment of the Western Lake Michigan drainages-analysis of available information on nutrients and suspended sediment, water years 1971-90: U.S. Geological Survey Water Resources Investigations Report 96-4012, $165 \mathrm{p}$.

Rose, William J,. and Graczyk, David J., 1996, Sediment transport, particle size, and loads in North Fish Creek in Bayfield County, Wisconsin, water years 1990-91: U.S. Geological Survey WaterResources Investigations Report 95-4222, $18 \mathrm{p}$.

Batten, W.G., and Lidwin, R.A., 1996, Water resources of the Lac du Flambeau Indian Reservation, Wisconsin, 1981-86: U.S. Geological Survey Water-Resources Investigations Report 94-4025, 42 p., 3 pls.

Sullivan, D.J., Peterson, E.M., and Richards, K.D., 1995, Environmental setting of fixed sites in the Western Lake Michigan Drainages, Michigan and Wisconsin: U.S. Geological Survey WaterResources Investigations Report 95-4211-A, 30 p.

Batten, W. G., and Lidwin, R.A., 1995, Water resources of the Bad River Indian Reservation, northern Wisconsin: U.S. Geological Survey Water-Resources Investigations Report 95-4207, 45 p., $2 \mathrm{pl}$.
Conlon, T. D., 1995, Hydrogeology of southwestern Sheboygan County, Wisconsin, in the vicinity of the Kettle Moraine Springs Fish Hatchery: U.S. Geological Survey Water-Resources Investigations Report 94-4106, $17 \mathrm{p}$

Corsi, S. R., and Schuler, J.G., 1995, Discharge ratings for tainter gates and roller gates at Lock and Dam No. 7 on the Mississippi River. La Crescent, Minnesota: U.S. Geological Survey Water Resources Investigations Report 95-4089, 17 p.

DeWild, John F., and Krohelski, James T., 1995, Radon-222 concentrations in ground water and soil gas on Indian Reservations in Wisconsin: U.S. Geological Survey Water-Resources Investigations Report 95-4088, 12 p.

Kammerer, P.A., Jr., 1995, Ground-water flow and quality in Wisconsin's shallow aquifer system: U.S. Geological Survey Water-Resources Investigations Report 90-4171, 42 p., 2 pl.

Goddard, Gerald L., and Field, Stephen J., 1994, Hydrology and water quality of Whitewater and Rice Lakes in southeastem Wisconsin, 1990-91: U.S. Geological Survey Water-Resources Investigations Report 94-4101, 36 p.

Krohelski, James T., Kammerer, Jr., Phil A., and Conlon, Terrence D., 1994, Water resources of the Menominee Indian Reservation of Wisconsin: U.S. Geological Survey Water-Resources Investigations Report 93-4053, 54 p., 4 pl.

Rose, William J., 1993, Hydrology of Little Rock Lake in Vilas County, north-central Wisconsin: U.S. Geological Survey WaterResources Investigations Report 93-4139, $22 \mathrm{p}$.

Graczyk, D.J., 1993, Surface-water hydrology and quality, and macroinvertebrate and smallmouth bass populations in four stream basins in southwestern Wisconsin, 1987-90: U.S. Geological Survey Water-Resources Investigations Repor 93-4024, 70 p.

Batten, W.G., and Conlon, T.D., 1993, Hydrogeology of glacial deposits in a preglacial bedrock valley, Waukesha County, Wisconsin: U.S. Geological Survey Water-Resources Investigations Report 92-4077, 15 p.

House, L.B., 1993, Simulation of the effects of hypothetical residential development on water levels in Graber Pond. Middleton, Wisconsin: U.S. Geological Survey Water-Resources Investigations Report 92-4029, $10 \mathrm{p}$.

Krohelski, J.T., and Lidwin, R.A., 1993, Hydrology and water quality of the Forest County Potawatomi Indian Reservation, Wisconsin: U.S. Geological Survey Water-Resources Investigations Report $91-4136,24 \mathrm{p}$.

Rose, William J., 1993, Water and phosphorus budgets and trophic state, Balsam Lake, northwestern Wisconsin, 1987-1989: U.S Geological Survey Water-Resources Investigations Report 91$4125,28 \mathrm{p}$.

Field, S.J., 1993, Hydrology and water quality of Powers Lake, southeastern Wisconsin: U.S. Geological Survey Water-Resources Investigations Report 90-4126, 36 p.

Field, Stephen J., 1993, Hydrology and water quality of Wind Lake in southeastem Wisconsin: U.S. Geological Survey WaterResources Investigations Report 91-4107,61 p.

Hughes, P.E., 1993, Hydrology, water quality, trophic status, and aquatic plants of Fowler Lake, Wisconsin: U.S. Geological Survey Water-Resources Investigations Report 91-4076, $44 \mathrm{p}$.

Krug, William R., Conger, Duane H., and Gebert, Warren A., 1992 Flood-frequency characteristics of Wisconsin streams: U.S. Geological Survey Water-Resources Investigations Report 914128,185 p., 2 pls. 
Rose, W.J., 1992, Sediment transport, particle sizes, and loads in lower reaches of the Chippewa, Black, and Wisconsin Rivers in western Wisconsin: U.S. Geological Survey Water-Resources Investigations Report 90-4124, 38 p.

Wentz, D.A., and Rose, W.J., 1991, Hydrology of Lakes Clara and Vandercook in North-Central Wisconsin: U.S. Geological Survey Water-Resources Investigations Report 89-4204, 24 p.

Patterson, G. L., 1990, Ground-water levels and quality at Crex Meadows Wildlife Area, Burnett County, Wisconsin: U.S. Geological Survey Water-Resources Investigations Report 89 . $4129,19 \mathrm{p}$.

Field, S.J., and Graczyk, D.J., 1990, Hydrology, aquatic macrophytes, and water quality of Black Earth Creek and its tributaries, Dane County, Wisconsin, 1985-86: U.S. Geological Survey WaterResources Investigations Report 89-4089, 44 p

Krug, W.R., Gebert, W.A., Graczyk, D.J., Stevens, D.L., Jr., Rochelle, B.P., Church, M.R., and Campbell, W.G., 1988, Runoff map for the Northeastern, Southeastern, and Mid-Atlantic United States for water years 1951-80: U.S. Geological Survey WaterResources Investigations Report 88-4094, 44 p.

Rose, William J., 1988, Water resources of the Apostle Islands National Lakeshore, Northern Wisconsin: U.S. Geological Survey Water-Resources Investigations Report 87-4220, 44 p.

Field, Stephen J., and Duerk, Marvin D., 1988, Hydrology and water quality of Delavan Lake in southeastern Wisconsin: U.S. Geological Survey Water-Resources Investigations Report 87. $4168,61 \mathrm{p}$.

Walker, J.F., Osen, L.L., and Hughes, P.E., 1987, Cost effectiveness of the U.S. Geological Survey's stream-gaging program in Wisconsin: U.S. Geological Survey Water-Resources Investigations Report 86-4125, $44 \mathrm{p}$.

Krohelski, J.T., Ellefson, B.R., and Storlie, C.A., 1987, Estimated use of ground water for irrigation in Wisconsin, 1984: U.S. Geological Survey Water-Resources Investigations Report 864079, 12 p., 1 pl.

House, L.B., 1987, Simulation of unsteady flow in the Milwaukee Harbor Estuary at Milwaukee, Wisconsin: U.S. Geological Survey Water-Resources Investigations Report 86-4050, 19 p.

Conger, D.H., 1986, Estimating magnitude and frequency of floods for Wisconsin urban streams: U.S. Geological Survey WaterResources Investigations Report 86-4005, $18 \mathrm{p}$.

Graczyk, D.J., 1986, Water quality in the St. Croix National Scenic Riverway, Wisconsin: U.S. Geological Survey Water-Resources Investigations Report 85-4319, 48 p.

Field, S.J., 1986, Relations between precipitation, streamflow, and water quality in the Galena River basin, Wisconsin: U.S. Geological Survey Water-Resources Investigations Report 85$4214,48 \mathrm{p}$.

Emmons, P.J., 1987, An evaluation of the bedrock aquifer system in northeastem Wisconsin: U.S. Geological Survey WaterResources Investigations Report 85-4199, 48 p.

Krug, W.R., and Goddard, G.L., 1986, Effects of urbanization on streamflow, sediment loads, and channel morphology in Pheasant Branch basin near Middleton, Wisconsin: U.S. Geological Survey Water-Resources Investigations Report 85-4068, 82 p.

Cotter, R.D., 1986, Hydrogeology and ground-water quality of Lannon-Sussex Area, northeastern Waukesha County, Wisconsin: U.S. Geological Survey Water-Resources Investigations Report 84-4213, 28 p.
Field, S.J., 1985, Nonpoint-source discharges and water quality of Elk Creek basin, west-central Wisconsin: U.S. Geological Survey Water-Resources Investigations Report 84-4094, 38 p.

Field, S.J., and Lidwin, R.A., 1984, An assessment of nonpoint-source discharges, streamflow, and water quality in Onion River, Wisconsin: U.S. Geological Survey Water-Resource Investigations Report 84-4066, 78 p.

House, L.B., 1984, Effects of urbanization on three ponds in Middleton, Wisconsin: U.S. Geological Survey Water-Resources Investigations Report 84-4051, $17 \mathrm{p}$.

Kammerer, P.A., Jr., 1984, An overview of ground-water-quality data in Wisconsin: U.S. Geological Survey Water-Resources Investigations Report 83-4239, $58 \mathrm{p}$.

Krug, W.R., and House, L.B., 1984, Evaluation of altemative reservoir-management practices in the Rock River basin, Wisconsin: U.S. Geological Survey Water-Resources Investigations Report 83-4186, $21 \mathrm{p}$

Duerk, M.D., 1983, Automatic dilution gaging of rapidly varying flow: U.S. Geological Survey Water-Resources Investigations Report $83-4088,17 \mathrm{p}$

Kammerer, P.A., Jr., Lidwin, R.A., Mason, J.W., and Narf, R.P., 1983 Aquatic biology in Nederlo Creek, southwestern Wisconsin: U.S Geological Survey Water Resources Investigations 82-56, 27 p.

Lawrence, C.L., and Ellefson, B.R., 1982, Water use in Wisconsin, 1979: U.S. Geological Survey Water-Resources Investigations $82-444,98$ p.

Wentz, Dennis A., and Graczyk, David J., 1982, Effects of a floodwater-retarding structure on the hydrology and ecology of Trout Creek in southwestern Wisconsin: U.S. Geological Survey Water-Resources Investigations 82-23, 68 p.

Holmstrom, B.K., 1982, Low-flow characteristics of streams in the Lake Michigan basin, Wisconsin: U.S. Geological Survey WaterResources Investigations Open-File Report 81-1193, 102 p.

House, Leo B., 1981, An assessment of streamflow, water quality, and the effects of construction on impoundment on Bridge Creek at Augusta, Wisconsin: U.S. Geological Survey Water-Resources Investigations Open-File Report 81-1192, $25 \mathrm{p}$

Field, S.J., and Lidwin, R.A., 1982, Water-quality assessment of Steiner Branch basin, Lafayette County, Wisconsin: U.S Geological Survey Water-Resources Investigations 81-52, 58 p.

Gebert, W.A., 1982, Low-flow characteristics of streams in the Central Wisconsin River basin, Wisconsin: U.S. Geological Survey Water-Resources Investigations Open-File Report 81-495, 99 p.

Conger, Duane H., 1981, Techniques for estimating magnitude and frequency of floods for Wisconsin streams: U.S. Geological Survey Water-Resources Investigations Open-File Report 80$1214,116 \mathrm{p}$

Krug, William R., and House, Leo B., 1980, Streamflow model of Wisconsin River for estimating flood frequency and volume: U.S. Geological Survey Water-Resources Investigations 80$1103,44 \mathrm{p}$

Holmstrom, B.K., 1980, Low-flow characteristics of streams in the Menominee-Oconto-Peshtigo River basin, Wisconsin: WaterResources Investigations Open-File Report 80-749, 82 p.

1980, Low-flow characteristics of streams in the St. Croix River basin, Wisconsin: U.S. Geological Survey Water-Resources Investigations Open-File Report 80-696, 62 p. 
Gebert, W.A., 1980, Low-flow characteristics of streams in the upper Wisconsin River basin, Wisconsin: U.S. Geological Survey Water-Resources Investigations Open-File Report 80-691, 60 p.

Krug, William R., 1981, Hydrologic effects of proposed changes in management practices, Winnebago Pool, Wisconsin: U.S. Geological Survey Water-Resources Investigations 80-107, 19 p.

House, Leo B., and Skavroneck, Steven, 1981, Comparison of the propane-area tracer method and predictive equations for determination of stream-reaeration coefficients on two small streams in Wisconsin: U.S. Geological Survey Water-Resources Investigations $80-105,18 \mathrm{p}$.

Kontis, A.L., and Mandle, R.J., 1980, Data-base system for northern Midwest regional aquifer-system analysis: U.S. Geological Survey Water-Resources Investigations 80-104, 27 p.

Grant, R.S., and Goddard, Gerald, 1980, Channel erosion and sediment transport in Pheasant Branch basin near Middleton, Wisconsin, a preliminary report: U.S. Geological Survey Water-Resources Investigations Open-File Report 80-161, 19 p., 11 figs., 3 tables.

McLeod, R.S., 1980, The effects of using ground water to maintain water levels of Cedar Lake, Wisconsin: U.S. Geological Survey Water-Resources Investigations 80-23, 35 p.

Grant, R.S., and Skavroneck, Steven, 1980, Comparison of tracer methods and predictive models for determination of stream-reaeration coefficients on three small streams in Wisconsin: U.S. Geological Survey Water-Resources Investigations 80-19, $36 \mathrm{p}$.

Hindall, S.M., 1979, Ground-water quality in selected areas of Wisconsin: U.S. Geological Survey Water-Resources Investigations Open-File Report 79-1594, 20 p.

Stedfast, D.A., 1979, Low-flow characteristics of streams in the Pecatonica-Sugar River basin, Wisconsin: U.S. Geological Survey Water-Resources Investigations Open-File Report 79$1274,92 \mathrm{p}$.

Grant, R.S., and Goddard, Gerald, 1979, Urban storm-runoff modeling-Madison, Wisconsin: U.S. Geological Survey WaterResources Investigations Open-File Report 79-1273, 20 p.

Novitzki, R.P., and Holmstrom, B.K., 1979, Monthly and annual water budgets of Lake Wingra, Madison, Wisconsin, 1971-77: U.S. Geological Survey Water-Resources Investigations 79-100, 31 p.

Kammerer, P.A., and Sherrill, M.G., 1979, Hydrology and water quality in the Nederlo Creek basin before construction of two waterretention structures: U.S. Geological Survey Water-Resources Investigations $79-95,42 \mathrm{p}$.

Gebert, W.A., 1979, Low-flow characteristics of streams in Lake Superior basin, Wisconsin: U.S. Geological Survey WaterResources Investigations 79-38, $74 \mathrm{p}$.

Holmstrom, B.K., 1979, Low-flow characteristics of Wisconsin streams at sewage-treatment plants and industrial plants: U.S. Geological Survey Water-Resources Investigations 79-31, 123 p.

Gebert, W.A., 1979, Red Cedar River basin, Wisconsin: Low-flow characteristics: U.S. Geological Survey Water-Resources Investigations $79-29,12 \mathrm{p}$

Holmstrom, B.K., 1979, Low-flow characteristics of streams in the Trempealeau-Black River basin, Wisconsin: U.S. Geological Survey Water-Resources Investigations 79-9, $79 \mathrm{p}$.

Sherrill, M.G., 1979, Contamination potential in the Silurian dolomite aquifer, eastern Wisconsin: U.S. Geological Survey WaterResources Investigations 78-108, 2 pls.
Holmstrom, B.K., 1978, Low-flow characteristics of streams in the Rock-Fox River basin, Wisconsin: U.S. Geological Survey Water-Resources Investigations 78-85, $98 \mathrm{p}$.

Rathbun, R.E., and Grant, R.S., 1978, Comparison of the radioactive and modified techniques for measurement of stream reaeration coefficients: U.S. Geological Survey Water-Resources Investigations $78-68,65 \mathrm{p}$.

Field, S.J., 1978, Ten-year low mean monthly discharge determinations for ungaged streams near waste-stabilization ponds in Wisconsin: U.S. Geological Survey Water-Resources Investigations $78-49,16 \mathrm{p}$.

Novitzki, R.P., 1978, Hydrology of the Nevin wetland near Madison, Wisconsin: U.S. Geological Survey Water-Resources Investigations $78-48,25 \mathrm{p}$.

Grant, R.S., 1978, Reaeration capacity of the Rock River between Lake Koshkonong, Wisconsin, and Rockton, Illinois: U.S. Geological Survey Water-Resources lnvestigations 77-128, 33 p.

Gebert, W.A., 1978, Low-flow characteristics of streams in the lower Wisconsin River basin: U.S. Geological Survey Water-Resources Investigations $77-118,80 \mathrm{p}$.

Gebert, W.A., and Holmstrom, B.K., 1977, Low-flow characteristics at gaging stations on the Wisconsin, Fox, and Wolf Rivers, Wisconsin: U.S. Geological Survey Water-Resources Investigations $77-27,20 \mathrm{p}$.

Rose, W.J., 1977, Hydrologic considerations associated with dredging spring ponds in Wisconsin: U.S. Geological Survey WaterResources Investigations 77-18, $35 \mathrm{p}$.

Krug, W.R., 1976, Simulation of streamflow of Flambeau River at Park Falls, Wisconsin, to define low-flow characteristics: U.S. Geological Survey Water-Resources Investigations 76-116, 14 p.

Grant, R.S., 1976, Reaeration of coefficient measurements of 10 small streams in Wisconsin using radioactive tracers - with a section on the energy-dissipation model: U.S. Geological Survey WaterResources Investigations 76-96, $50 \mathrm{p}$.

Novitzki, R.P., 1976, Recycling ground water in Waushara County, Wisconsin: Resource management for cold-water fish hatcheries: U.S. Geological Survey Water-Resources Investigations 76-20, $60 \mathrm{p}$.

Hindall, S.M., 1976, Measurement and prediction of sediment yields in Wisconsin streams: U.S. Geological Survey Water-Resources Investigations $54-75,27 \mathrm{p}$

Oakes, E.L., Hendrickson, G.E., and Zuehls, E.E., 1975, Hydrology of the Lake Wingra basin, Dane County, Wisconsin: U.S. Geological Survey Water-Resources Investigations 17-75, $31 \mathrm{p}$.

Gebert. W.A., and Holmstrom, B.K., 1974, Low-flow characteristics of Wisconsin streams at sewage-treatment plants: U.S. Geological Survey Water-Resources Investigations 45-74, 101 p.

Hendrickson, G.E., Knutilla, R.L., and Doonan, C.J., 1973, Hydrology and recreation of selected cold-water rivers of the St. Lawrence River basin in Michigan, New York, and Wisconsin: U.S. Geological Survey Water-Resources Investigations 8-73, 73 p.

\section{OPEN-FILE REPORTS}

Corsi, S.R., Greb, S.R., Bannerman, R.T., and Pitt, R.E., 1999, Evaluation of the multi-chambered treatment train, a retrofit water-quality management device: U.S. Geological Survey Open-File Report 99-270, 24 p. 
Maertz, D.E., 1999, Water-resources investigations in Wisconsin, 1999: U.S. Geological Survey Open-File Report 99-229, 112 p.

Wisconsin District Lake-Studies Team, 1999, Water-quality and lakestage data for Wisconsin lakes, water year 1998: U.S. Geological Survey Open-File Report 99-98, 143 p

Krug, W. R., 1999, Simulation of the effects of operating Lakes Mendota, Monona, and Waubesa, south-central Wisconsin, as multipurpose reservoirs to maintain dry-weather flow: U.S. Geological Survey Open-File Report 99-67, 18 p.

Hall, D.W., Behrendt, T.E., and Hughes, P.E., 1998, temperature, pH, conductance, and dissolved oxygen in cross sections of 11 Lake Michigan tributaries, 1994-95: U.S. Geological Survey OpenFile Report 98-567, 85 p.

Maertz, D.E., 1998, Water-resources investigations in Wisconsin: U.S. Geological Survey Open-File Report 98-295, 96p.

Wisconsin District Lake-Studies Team, 1998, Water-quality and lakestage data for Wisconsin lakes, water year 1997: U.S. Geological Survey Open-File Report 98-78, 129 p.

Ellefson, B.R., Fan, C.H., and Ripley, J.L., 1997, Water use in Wisconsin, 1995: U.S. Geological Survey Open-File Report 97-356, 1 sheet.

Maertz, D.E., 1997, Water-resources investigations in Wisconsin, U.S. Geological Survey Open-File Report 97-351, 91 p.

Wisconsin District Lake-Studies Team, 1997, Water-quality and lakestage data for Wisconsin lakes, water year 1996: U.S. Geological Survey Open-File Report 97-123, 134 p.

Rappold, K.F., Wierl, J.A., and Amerson, F.U., 1997, Watershed characteristics and land management in the nonpoint-source evaluation monitoring watersheds in Wisconsin: U.S. Geological Survey Open-File Report 97-119, 39 p.

Owens, D.W., Corsi, S.R., and Rappold, K.F., 1997, Evaluation of nonpoint-source contamination, Wisconsin: Selected topics for water year 1995: U.S. Geological Survey Open-File Report 96-661A, $41 \mathrm{p}$.

Bannerman, Roger T., Legg, Andrew D., and Greb, Steven R., 1996, Quality of Wisconsin stormwater 1989-94: U.S. Geological Survey Open-File Report 96-458, 26 p.

Maertz, D.E., 1996, Water-resources investigations in Wisconsin, U.S. Geological Survey Open-File Report 96-333, 74 p.

Wisconsin District Lake-Studies Team, 1996, Water-quality and lakestage data for Wisconsin lakes, water year 1995: U.S. Geological Survey Open-File Report 96-168, 123 p.

Wierl, J.A., Rappold, K.F., and Amerson, F.U., 1996, Summary of the land-use inventory for the nonpoint-source evaluation monitoring watersheds in Wisconsin: U.S. Geological Survey Open-File Report 96-123, 23 p.

Steuer, J.J., Selbig, W.R. and Hornewer, N.J., 1996, Contaminant concentrations in stormwater from eight Lake Superior basin cities, 1993-94: U.S. Geological Survey Open-File Report 96-122, $16 \mathrm{p}$.

Waschbusch, R.J., 1996, Stormwater-runoff data, Madison, Wisconsin, 1993-94: U.S. Geological Survey Open-File Report 95-733, $33 \mathrm{p}$.

Maertz, D.E., 1995, Water-resources investigations in Wisconsin, 1995: U.S. Geological Survey Open-File Report 95-328, 84 p.
Walker, J.R., Graczyk, D.J., Corsi, S.R., Owens, D.W., and Wierl, J.A., 1995, Evaluation of nonpoint-source contamination, Wisconsin: Land-use and best-management-practices inventory, selected streamwater-quality data, urban-watershed quality assurance and quality control, constituent loads in rural streams, and snowmeltrunoff analysis, water year 1994: U.S. Geological Survey OpenFile Report 95-320, 21 p.

Wisconsin District Lake-Studies Team, 1995, Water-quality and lakestage data for Wisconsin lakes, water year 1994: U.S. Geological Survey Open-File Report 95-190, 157 p.

Peters, C.A., 1995, National Water-Quality Assessment Program, Western Lake Michigan Drainages-Summaries of Liaison Committee Meeting, Green Bay, Wisconsin, March 28-29, 1995: U.S. Geological Survey Open-File Report 95-163, 57 p.

Corsi, S.R., Walker, J.F., Graczyk, D.J., Greb, S.R., Owens, D.W., and Rappold, K.F., 1995, Evaluation of nonpoint-source contamination, Wisconsin: Selected streamwater-quality data, land-use and best-management practices inventory, and quality assurance and quality control, water year 1993: U.S. Geological Survey OpenFile Report 94-707, $57 \mathrm{p}$.

Krohelski, J.T., and Batten, W.G., 1995, Simulation of stage and the hydrologic budget of Devils Lake, Sauk County, Wisconsin: U.S. Geological Survey Open-File Report 94-348, 22 p.

House, Leo B., 1995, Distribution and transport of polychlorinated biphenyls in Little Lake Butte des Morts, Fox River, Wisconsin, April 1987-October 1988: U.S. Geological Survey Open-File Report 93-31, 43 p., 1 pl.

Maertz, D.E., 1994, Water-resources investigations in Wisconsin, 1994: U.S. Geological Survey Open-File Report 94-321.

Graczyk, D.J., Walker, J.F., Greb, S.R., Corsi, S.R., and Owens, D.W., 1993, Evaluation of nonpoint-source contamination, Wisconsin: Selected data for 1992 water year: U.S. Geological Survey OpenFile Report 93-630, 48 p.

House, Leo B., Waschbusch, Robert J., and Hughes, Peter E., 1993, Water quality of an urban wet detention pond in Madison, Wisconsin, 1987-88: U.S. Geological Survey Open-File Report 93-172, $57 \mathrm{p}$.

House, L.B., Hughes, P.E., and Waschbusch, R.J., 1993, Concentrations and loads of polychlorinated biphenyls in major tributaries entering Green Bay, Lake Michigan, 1989-90: U.S. Geological Survey Open-File Report 93-132, 41 p.

Walker, John F., 1993, Techniques for detecting effects of urban and rural land-use practices on stream-water chemistry in selected watersheds in Texas, Minnesota, and Illinois: U.S. Geological Survey Open-File Report 93-130, 16 p.

Maertz, D.E., 1993, Water-resources investigations in Wisconsin, 1993: U.S. Geological Survey Open-File Report 93-129, 91 p.

Ellefson, B.R., Sabin, T.J., and Krohelski, J.T., 1993, Water use in Wisconsin, 1990: U.S. Geological Survey Open-File Report 93118,1 sheet.

Maertz, D.E., 1992, Water-resources investigations in Wisconsin: Programs and activities of the U.S. Geological Survey, 19911992: U.S. Geological Survey Open-File Report 92-125, 93 p.

Elder, J.F., Krabbenhoft, D.P, and Walker, J.F., 1992, Water, energy, and biogeochemical budgets (WEBB) program: Data availability and research at the northern temperate lakes site, Wisconsin: U.S. Geological Survey Open-File Report 92-48, 15 p. 
Krabbenhoft, D.P., and Krohelski, J.T., 1992, Data on water quality, lake sediment, and lake-level fluctuation, St. Croix Indian Reservation, Wisconsin, 1981-87: U.S. Geological Survey Open-File Report 92-26, 53 p.

Hughes, P.E., 1993, Hydrologic and water-quality data for the East River Basin of northeastem Wisconsin: U.S. Geological Survey Open-File Report 89-245, 91 p.

Setmire, J.G., 1991, National Water-Quality Assessment Program Western Lake Michigan Drainage Basin: U.S. Geological Survey Open-File Report 91-161, Water Fact Sheet, 2 p.

Melcher, N.B. and Walker, J.F., 1990, Evaluation of selected methods for determining streamflow during periods of ice effect: U.S. Geological Survey Open-File Report 90-554, 51 p.

U.S. Geological Survey, 1990, The effects of the 1988 drought on the water resources of Wisconsin: U.S. Geological Survey Open-File Report 90-149, Water Fact Sheet, 2 p.

House, L.B., 1990, Data on polychlorinated biphenyls, dieldrin, lead, and cadmium in Wisconsin and upper Michigan tributaries to Green Bay, July 1987 through April 1988: U.S. Geological Survey Open-File Report 89-52, 11 p.

Gebert, Warren A., Graczyk, David J., and Krug, William R., 1988, Runoff for selected sites in Shenandoah National Park, Virginia, July 18, 1981 through July 17, 1982: U.S. Geological Survey Open-File Report 88-98, 13 p.

Ellefson, B.R., Rury, Kraig S., and Krohelski, James T., 1988, Water use in Wisconsin, 1985: U.S. Geological Survey Open-File Report 87-699.

Krug, W.R., Gebert, W.A., and Graczyk, D.J., 1989, Preparation of average annual runoff map of the United States, 1951-80: U.S. Geological Survey Open-File Report 87-535, 414 p.

Krug, William R., Ostenso, Nile A., and Krohelski, James T., 1988, Prediction of the effects of mine dewatering on four lakes near Crandon, Wisconsin, by use of a water-budget model: U.S. Geological Survey Open-File Report 87-471, 63 p.

Graczyk, David J., Gebert, Warren A., Krug, William R., and Allord, G.J., 1987, Maps of runoff in the Northeastern Region and southern Blue Ridge Province of the United States during selected time periods in 1983-85: U.S. Geological Survey Open-File Report 87-106, 8 p., 3 pl.

Graczyk, David J., Krug, William R., and Gebert, Warren A., 1986, A history of annual streamflows from the 21 water-resource regions in the United States and Puerto Rico, 1951-83: U.S. Geological Survey Open-File Report 86-128, 30 p.

Henrich, E.W., 1984, Drainage area data for Wisconsin Streams: U.S. Geological Survey Open-File Report 83-933, 322 p.

Lawrence, C.L., Ellefson, B.R., and Cotter, R.D., 1984, Public-supply pumpage in Wisconsin in 1979: U.S. Geological Survey OpenFile Report 83-931, $40 \mathrm{p}$.

Lawrence, C.L., and Ellefson, B.R., Water use in Wisconsin, 1979 , U.S. Geological Survey Open-File Report 82-444, 98 p.

Novitzki, R.P., 1979, Streamflow estimates in selected Wisconsin streams: U.S. Geological Survey Open-File Report 79-1282, $11 \mathrm{p}$.

Harr, C.A., and Novitzki, R.P., 1979, Availability of supplemental water supplies at salmonid fish-propagation stations in Wisconsin: U.S. Geological Survey Open-File Report 79-1170, 13 p.
Krug, W.R., 1979, Simulation of streamflow of Rock River at Lake Koshkonong, Wisconsin, to determine effects of withdrawal of powerplant-cooling water: U.S. Geological Survey Open-File Report 79-253, $21 \mathrm{p}$.

McLeod, R.S., 1978, Water-level declines in the Madison area, Dane County, Wisconsin: U.S. Geological Survey Open-File Report 78-936, $15 \mathrm{p}$

Field, S.J., 1978, Low-flow characteristics of small streams in proposed Public Law 566 basins: U.S. Geological Survey Open-File Report 78-664, 32 p.

Hindall, S.M., 1978, Suspended-sediment transport in the Big Eau Pleine River basin, central Wisconsin: U.S. Geological Survey Open-File Report 78-313, 12 p.

Lawrence, C.L., 1976, Regional flood limits of lower Yahara River, Lake Waubesa and south, in Dane County, Wisconsin: U.S Geological Survey Open-File Report 76-805, 20 p.

Krug, W.R., 1976, Probable maximum flood at Lake Chippewa near Winter, Wisconsin: U.S. Geological Survey Open-File Report 76-800, $14 \mathrm{p}$.

Grant, R.S., 1976, Waste-assimilation study of Koshkonong Creek below sewage-treatment plant at Sun Prairie, Wisconsin: U.S. Geological Survey Open-File Report 76-655, 44 p.

Lawrence, C.L., 1976, Regional flood limits of upper Yahara River in Dane County, Wisconsin: U.S. Geological Survey Open-File Report 76-448, $15 \mathrm{p}$.

Holmstrom, B.K., 1976, Low-flow characteristics and mean annual discharge of North Branch Manitowoc River at Potter, Wisconsin: U.S. Geological Survey Open-File Report 76-204, $20 \mathrm{p}$.

Krug, W.R., 1976, Flood-plain delineation for regional flood in Dane County, Wisconsin: U.S. Geological Survey Open-File Report $76-164,168 \mathrm{p}$.

Field, S.J., 1975, Low-flow study of the Pike River basin, Racine and Kenosha Counties, Wisconsin: U.S. Geological Survey OpenFile Report 75-653, $10 \mathrm{p}$

Green, J.H., 1975, Flow characteristics of the lower Wisconsin River: U.S. Geological Survey Open-File Report 75-582, 9 p.

Holmstrom, B.K., 1975, Streamflow characteristics of Klawitter Creek basin near Westfield, Wisconsin: U.S. Geological Survey Open. File Report 75-527, 14 p.

Krug, W.R., 1975, Analysis of operational plan for Lake Chippewa near Winter, Wisconsin: U.S. Geological Survey Open-File Report 75-487, $17 \mathrm{p}$.

Holmstrom, B.K., 1975, Low-flow characteristics of the Eau Claire River basin near Antigo, Wisconsin: U.S. Geological Survey Open-File Report 75-336, $19 \mathrm{p}$.

Gebert, W.A., 1974, Streamflow characteristics of Little Wolf RiverHolt Creek basin near Galloway, Wisconsin: U.S. Geological Survey Open-File Report, $10 \mathrm{p}$.

Lawrence, C.L., and Holmstrom, B.K., 1973, Floods on Yahara River tributaries, Dane County, Wisconsin: U.S. Geological Survey Open-File Report, 19 p.

Grant, R.S., Krug, W.R., and Duerk, M.D., 1973, Floodplain and floodway delineation for regional flood in central Marathon County, Wisconsin: U.S. Geological Survey Open-File Report, 33 p. 
Holmstrom, B.K., Gebert, W.A., and Borman, R.G., 1973, Alder Creek hydrology, Wisconsin: U.S. Geological Survey Open-File Report, $28 \mathrm{p}$.

Lawrence, C.L., and Holmstrom, B.K., 1972, Flood in Starkweather Creek basin, Madison, Wisconsin: U.S. Geological Survey OpenFile Report, $15 \mathrm{p}$.

Holmstrom, B.K., 1972, Drainage-area data for Wisconsin streams: U.S. Geological Survey Open-File Report, 74 p. (Updated 1973, 1974, 1978, and 1979.)

Hindall, S.M., 1972, Sediment yields of Wisconsin streams: U.S. Geological Survey Open-File Report, 2 p.

Weeks, E.P., and Stangland, H.G., 1971, Effects of irrigation on streamflow in the central sand plains of Wisconsin: U.S. Geological Survey Open-File Report, 113 p.

Conger, D.H., 1971, Estimating magnitude and frequency of floods in Wisconsin: U.S. Geological Survey Open-File Report, 200 p.

Holmstrom, B.K., and Lawrence, C.L., 1971, Floods on Yahara River, Lake Mendota to Lake Kegonsa, Dane County, Wisconsin: U.S. Geological Survey Open-File Report, 12 p.

Lawrence, C.L., and Holmstrom, B.K., 1971, Floods on Yahara River, Lake Kegonsa dam to countyline, Dane County, Wisconsin: U.S. Geological Survey Open-File Report, 10 p.

Shearman, J.O., and Lawrence, C.L., 1971, Floods on Yahara River upstream from Lake Mendota, Dane County, Wisconsin: U.S. Geological Survey Open-File Report, 7 p.

Gebert, W.A., 1971, Hydrology of Pine Creek: U.S. Geological Survey Open-File Report, 6 p.

1971, Hulbert Creek hydrology, southwestern Wisconsin: U.S. Geological Survey Open-File Report, 11 p.

Gonthier, J.B., 1970, Water resources of southeastern WisconsinMilwaukee River basin: U.S. Geological Survey Open-File Report, 138 p. (Extensively used in preparation of "A comprehensive plan for the Milwaukee River watershed", v. 1 and 2, 1970 and 1971, Southeastern Wisconsin Regional Planning Commission Report No. 13, v. 1, 514 p. and v. 2, 623 p.)

Hamilton, L.J., 1970, Availability of ground water in the lower Wisconsin River Valley, Wisconsin: U.S. Geological Survey Open-File Report, 45 p.

Campbell, R.E., and Dreher, F.C., 1970, A proposed stream-flow data program for Wisconsin: U.S. Geological Survey Open-File Report, $55 \mathrm{p}$.

Shearman, J.O., 1969, Evaluation of flood potential, part 2 of Flood. plain management-Lake Koshkonong: U.S. Geological Survey Open-File Report, 6 p.

Young, K.B., 1965, Effect of treated effluent diversion on Yahara River flow: U.S. Geological Survey Open-File Repon, 81 p.

1965, Supplement to report on flow characteristics of Wisconsin streams: U.S. Geological Survey Open-File Report, 81 p.

U.S. Geological Survey, 1964, Water-quality records in Michigan and Wisconsin: U.S. Geological Survey Open-File Report, 61 p.

Young, K.B., 1963, Flow characteristics of Wisconsin streams: U.S Geological Survey Open-File Report, 151 p.

Erickson, D.W., 1961, Floods in Wisconsin, magnitude and frequency: U.S. Geological Survey Open-File Report, 109 p.
1961, Wisconsin River near Dekorra, Wisconsin, flood-flow characteristics at proposed bridge site on the Wisconsin Freeway in Columbia County: U.S. Geological Survey Open-File Report, $13 \mathrm{p}$.

Spicer, H.C., and Edwards, G.J., 1955, Electrical resistivity measurements in the Neillsville area, Wisconsin: U.S. Geological Survey Open-File Report, 34 p.

1954, A resistivity survey to locate an aquifer in the glacial deposits near Marshfield, Wisconsin: U.S. Geological Survey Open-File Report, 76 p.

Drescher, W.J., 1948, Results of pumping tests on artesian wells in the Milwaukee-Waukesha area, Wisconsin: U.S. Geological Survey Open-File Report, 22 p.

\section{OPEN-FILE MAPS}

Gonthier, J.B., 1979, Water-table map of Waukesha County, Wisconsin: U.S. Geological Survey Water-Resources Investigations Open-File Map 79-43, 1 pl.

Sherrill, M.G., and Erickson, J.R., 1979, Water-table map of Walworth County, Wisconsin: U.S. Geological Survey Water-Resources Investigations Open-File Map 79-42, 1 pl.

Sherrill, M.G., and Schiller, J.J., 1979, Water-table map of Racine County, Wisconsin: U.S. Geological Survey Water-Resources Investigations Open-File Map 79-41, 1 pl.

Sherrill, M.G., Schiller, J.J., and Erickson, J.R., 1979, Water-table map of Milwaukee County, Wisconsin: U.S. Geological Survey Water-Resources Investigations Open-File Map 79-40, 1 pl.

Sherrill, M.G., and Schiller, J.J., 1979, Water-table map of Kenosha County, Wisconsin: U.S. Geological Survey Water-Resources Investigations Open-File Map 79-39, 1 pl.

Borman, R.G., 1976, Thickness of unconsolidated materials of Walworth County, Wisconsin: U.S. Geological Survey OpenFile Report 76-465, scale 1:62,500.

1976, Water-table map of Walworth County, Wisconsin: U.S Geological Survey Open-File Report 76-464, scale 1:62,500.

1976, Bedrock topography of Walworth County, Wisconsin: U.S. Geological Survey Open-File Report 76-463, scale 1:62,500.

1976, Bedrock geology of Walworth County, Wisconsin: U.S. Geological Survey Open-File Report 75-462, scale 1:62,500.

Gonthier, J.B., 1975, Bedrock topography of Waukesha County, Wisconsin: U.S. Geological Survey Open-File Report 75-572, scale 1:62,500.

1975, Water-table map of Waukesha County, Wisconsin: U.S. Geological Survey Open-File Report 75-571, scale 1:62,500.

1975, Bedrock geology of Waukesha County, Wisconsin: U.S. Geological Survey Open-File Report 75-570, scale 1:62,500.

Borman, R.G., 1971, Preliminary map showing thickness of glacial deposits in Wisconsin: U.S. Geological Survey Open-File Report, scale $1: 2,500,000$.

1971, Preliminary map of probable well yields from bedrock in Wisconsin: U.S. Geological Survey Open-File Report, scale $1: 2,500,000$. 
1971, Preliminary map of probable well yields from glacial deposits in Wisconsin: U.S. Geological Survey Open-File Report, scale $1: 2,500,000$

\section{ADMINISTRATIVE REPORTS}

Rose, W.J., 1979, Bedload in northwestem Wisconsin's Nemadji River: U.S. Geological Survey Administrative Report, 12 p.

Hindall, S.M., and Graczyk, D.J., 1978, St. Croix National Scenic Riverway flood-plain delineation and water quality monitoring: U.S. Geological Survey Administrative Report, 47 p.

Kammerer, P.A., and Lidwin, R.A., 1977, Water quality in the Pine River basin Richland and Vernon Counties, Wisconsin: U.S. Geological Survey Administrative Report, 93 p.

Novitzki, R.P., 1971, Hydrologic investigations of Heart Lake, Green Lake County, Wisconsin: U.S. Geological Survey Administrative Report, 9 p.

1971, Hydrologic investigations for the Woodruff Fish Hatchery, Oneida County, Wisconsin: U.S. Geological Survey Administrative Report, $4 \mathrm{p}$.

1971, Hydrologic investigations of a proposed reservoir site in Trempealeau County, Wisconsin: U.S. Geological Survey Administrative Report, 4 p.

\section{FACT SHEETS}

Hunt, Randall J., Graczyk, David J., and Rose, William J., 2000, Water flows in the Necedah National Wildlife Refuge: U.S. Geological Survey Fact Sheet 068-00, 4 p.

Graczyk, David J., Robertson, Dale M., Rose, William J., and Steuer, Jeffrey J., 2000, Comparison of water-quality samples collected by siphon samplers and automatic samplers in Wisconsin: U.S. Geological Survey Fact Sheet 067-00, 4 p.

Graczyk, D.J., Vanden Brook, J.P., and Rheineck, B.D., 1999, Herbicides in the Pecatonica, Trempealeau, and Yahara Rivers in Wisconsin, May 1997-July 1998: U.S. Geological Survey Fact Sheet 167-99, $9 \mathrm{p}$.

Wierl, Judy A., Giddings, Elise, M.P., and Bannerman, Roger T., 1998, Evaluation of a method for comparing phosphorus loads from barnyards and croplands in Otter Creek watershed, Wisconsin: U.S. Geological Survey Fact Sheet 168-98, 4 p.

Rose, W.J., and Robertson, D.M., 1998, Hydrology, water quality, and phosphorus loading of Kirby Lake, Barron County, Wisconsin: U.S. Geological Survey Fact Sheet 066-98, 4 p.

Stuntebeck, Todd D., and Bannerman, Roger T., 1998, Effectiveness of barnyard best management practices in Wisconsin: U.S. Geological Survey Fact Sheet 051-98, 4 p.

Team for evaluating the Wisconsin Water-Monitoring Network, 1998 , Plan for an integrated long-term water-monitoring network for Wisconsin: U.S. Geological Survey Fact Sheet 048-98, 4 p.

Corsi, Steven R., Graczyk, David J., Owens, David W., and Bannerman, Roger T., 1997, Unit-area loads of suspended sediment, suspended solids, and total phosphorus from small watersheds in Wisconsin: U.S. Geological Survey Fact Sheet 195-97, 4 p.

Graczyk, David J., and Vanden Brook, James P., 1997, Herbicides in the Pecatonica and Yahara Rivers in southwestern Wisconsin, May 1996-July 1996: U.S. Geological Survey Fact Sheet 175-97, $4 \mathrm{p}$.
Lenz, Bernard N., 1997, Feasibility of combining two aquatic benthic macroinvertebrate community databases for water-quality assessment: U.S. Geological Survey Fact Sheet 132-97, 4 p.

Hunt, Randall J., 1996. Do created wetlands replace the wetlands that are destroyed: U.S. Geological Survey Fact Sheet 246-96, 4 p.

Elder, John F., and Goddard, Gerald L., 1996, Sediment and nutrient trapping efficiency of a constructed wetland near Delavan Lake, Wisconsin, 1993-1995: U.S. Geological Survey Fact Sheet 232$96,4 \mathrm{p}$.

Kammerer, P.A., Jr., 1996, Hydrology and water quality of Park Lake, South-Central Wisconsin: U.S. Geological Survey Fact Sheet 197-96, 4 p.

Matzen, Amy M., and Saad, David A., 1996, Pesticides in ground water in the Western Lake Michigan drainages, Wisconsin and Michigan, 1983-1995: U.S. Geological Survey Fact Sheet 192-96, 4 p.

U.S. Geological Survey, 1996, Real-time streamflow conditions: U.S. Geological Survey Fact Sheet 190-96, 2 p.

Krabbenhoft, David P., 1996, Mercury studies in the Florida Everglades: U.S. Geological Survey Fact Sheet 166-96, 4 p.

Fitzgerald, Sharon A., and Steuer, Jeffrey J., 1996, The Fox River PCB transport study - stepping stone to a healthy Great Lakes ecosystem: U.S. Geological Survey Fact Sheet 116-96, 4 p.

Sullivan, Daniel J., and Richards, Kevin D., 1996, Pesticides in streams in the Western Lake Michigan drainages. Wisconsin and Michigan, 1993-95: U.S. Geological Survey Fact Sheet 107-96, 4 p.

Stuntebeck, Todd D., 1995, Evaluating barnyard best management practices in Wisconsin using upstream-downstream monitoring: U.S. Geological Survey Fact Sheet 221-95, 4 p.

Robertson, Dale M., and Saad, David A., 1995, Environmental factors used to subdivide the Western Lake Michigan Drainages into relatively homogeneous units for water-quality site selection: U.S. Geological Survey Fact Sheet 220-95, 4 p.

Krabbenhoft, D.P., and Rickert, D.A., 1995, Mercury contamination of aquatic ecosystems: U.S. Geological Survey Fact Sheet 216-95, $4 \mathrm{p}$

Saad, David A., 1995, Nitrate in ground water in the Western Lake Michigan Drainage Basin, Wisconsin and Michigan: U.S. Geological Survey Fact Sheet 070-94, 2 p.

\section{WISCONSIN GEOLOGICAL AND NATURAL HISTORY SURVEY INFORMATION CIRCULARS}

Batten, W.G., 1989, Hydrogeology of Wood County, Wisconsin: Wisconsin Geological and Natural History Survey Information Circular 60, 27 p., 2 pis.

Patterson, G.L., and Zaporozec, Alexander, 1988, Analysis of waterlevel fluctuations in Wisconsin wells: Wisconsin Geological and Natural History Survey Information Circular 63, $38 \mathrm{p}$.

Batten, W.G., 1987, Water resources of Langlade County, Wisconsin: Wisconsin Geological and Natural History Survey Information Circular 58, 28 p., 1 pl.

Krohelski, J.T., 1986, Hydrogeology and ground-water use and quality, Brown County, Wisconsin: Wisconsin Geological and Natural History Survey Information Circular 57, 42 p. 
House, L.B., 1986, Stage fluctuations of Wisconsin Lakes: Wisconsin Geological and Natural History Survey Information Circular No. $49,84 \mathrm{p}$.

Devaul, R.W., Harr, C.A., and Schiller, J.J., 1983, Ground-water resources and geology of Dodge County, Wisconsin: Wisconsin Geological and Natural History Survey Information Circular 44, $34 \mathrm{p}$.

Erickson, R.M., and Cotter, R.D., 1983, Trends in ground-water levels in Wisconsin through 1981: Wisconsin Geological and Natural History Survey Information Circular 43, 139 p.

Novitzki, R.P., 1982, Hydrology of Wisconsin Wetlands: Wisconsin Geological and Natural History Survey Information Circular 40, $22 \mathrm{p}$.

Kammerer, Phil A., Jr., Ground-water quality atlas of Wisconsin: Wisconsin Geological and Natural History Survey Information Circular 39, $39 \mathrm{p}$.

Young, H.L., and Batten, W.G., 1980, Ground-water resources and geology of Washington and Ozaukee Counties, Wisconsin: Wisconsin Geological and Natural History Survey Information Circular 38, $37 \mathrm{p}$.

Harr, C.A., Trotta, L.C., and Borman, R.G., 1978, Ground-water resources and geology of Columbia County, Wisconsin: Wisconsin Geological and Natural History Survey Information Circular 37, $30 \mathrm{p}$.

Hindall, S.M., 1978, Effects of irrigation on water quality in the sand plain of central Wisconsin: Wisconsin Geological and Natural History Survey Information Circular 36, 50 p.

Borman, R.G., 1976, Ground-water resources and geology of Walworth County, Wisconsin: Wisconsin Geological and Natural History Survey Information Circular 34, 45 p.

Borman, R.G., and Trotta, L.C., 1976, Ground-water resources and geology of Jefferson County, Wisconsin: Wisconsin Geological and Natural History Survey Information Circular 33, 31 p.

Borman, R.G., 1976, Ground-water resources and geology of St. Croix County, Wisconsin: Wisconsin Geological and Natural History Survey Information Circular 32, $30 \mathrm{p}$.

Bell, E.A., and Hindall, S.M., 1975, The availability of ground water for irrigation in the Rice Lake-Eau Claire area, Wisconsin: Wisconsin Geological and Natural History Survey Information Circular 31, $65 \mathrm{p}$.

McLeod, R.S., 1975, A digital-computer model for estimating hydrologic changes in the aquifer system in Dane County, Wisconsin: Wisconsin Geological and Natural History Survey Information Circular 30, $40 \mathrm{p}$.

Gonthier, J.B., 1975, Ground-water resources of Waukesha County, Wisconsin: Wisconsin Geological and Natural History Survey Information Circular 29, 47 p.

McLeod, R.S., 1975, A digital-computer model for estimating drawdown in the sandstone aquifer in Dane County, Wisconsin: Wisconsin Geological and Natural History Survey Information Circular 28, 91 p.

Holt, C.L.R., Jr., and Skinner, E.L., 1973, Ground-water quality in Wisconsin through 1972: Wisconsin Geological and Natural History Survey Information Circular 22, $148 \mathrm{p}$.

Erickson, R.M., 1972, Trends in ground-water levels in Wisconsin, 1967-71: Wisconsin Geological and Natural History Survey Information Circular 21, 40 p. (Supplement to Information Circular 9).
Holt, C.L.R., Jr., Cotter, R.D., Green, J.H., and Olcott, P.G., 1970, Hydrogeology of the Rock-Fox River basin of southeastern Wisconsin: Wisconsin Geological and Natural History Survey Information Circular 17, 47 p. (Prepared for the Annual Meeting of the Geological Society of America-Field Trip Guidebook).

Devaul, R.W., 1967, Trends in ground-water levels in Wisconsin through 1966: Wisconsin Geological and Natural History Survey Information Circular 9, $109 \mathrm{p}$.

Ryling, R.W., 1961, A preliminary study of the distribution of saline water in the bedrock aquifers of eastern Wisconsin: Wisconsin Geological and Natural History Survey Information Circular 5 , $23 \mathrm{p}$.

Drescher, W.J., 1956, Ground water in Wisconsin: Wisconsin Geological and Natural History Survey Information Circular 3, $37 \mathrm{p}$.

1955 , Some effects of precipitation on ground water in Wisconsin: Wisconsin Geological and Natural History Survey Information Circular 1, $17 \mathrm{p}$.

\section{WISCONSIN GEOLOGICAL AND NATURAL HISTORY SURVEY MISCELLANEOUS PAPERS}

Patterson, G.L., 1989, Water resources of Vilas County, Wisconsin Wisconsin Geological and Natural History Survey Miscellaneous Paper 89-1, $46 \mathrm{p}$.

\section{OTHER PUBLICATIONS}

Hunt, Randy and Zheng, Chunmiao, 1999, Newsletter: Debating complexity in modeling; Eos, Transactions, American Geophysical Union, v. 80, no. 3, p. 29.

Hunt, R.J., Walker, J.F., and Krabbenhoft, D.P., 1999, Characterizing hydrology and the importance of ground-water discharge in natural and constructed wetlands: Wetlands, no. 19, v. 2, p. 458-472

Lathrop, R.C., Carpenter, S.R., and Robertson, D.M., 1999, Summer water clarity responses to phosphorus, Daphnia grazing, and internal mixing in Lake Mendota: Limnology and Oceanography, v. 44 , no. 1 , p. $137-146$

Panuska, J.C., and Robertson, D.M., 1999, Estimating phosphorus concentrations following alum treatment using apparent settling velocities: Lakes and Reservoir Management, v. 15, no. 1, p. 28-38.

Cleckner, Lisa B., Garrison, Paul J., Hurley, James P., Olson, Mark L. and Krabbenhoft, David P., 1998, Trophic transfer of methyl mercury in the northern Florida Everglades: Biogeochemistry, $v$. 40 , p. $347-361$.

Hunt, R.J., Anderson, M.P., and Kelson, V.A., 1998, Improving a complex finite difference groundwater-flow model through the use of an analytic element screening model: Ground Water, v. 36, no. 6, p. 1011-1017

Hunt, R.J., Bullen, T.D., Krabbenhoft, D.P., and Kendall, C., 1998, Using stable isotopes of water and strontium to investigate the hydrology of a natural and constructed wetland: Ground Water, v. 36 , no. 3 , p. $434-443$.

Hurley, James P., Krabbenhoft, David P., Cleckner, Lisa B., Olson, Mark L., Aiken, George R., and Rawlik Jr., Peter S., 1998, System controls on the aqueous distribution of mercury in the north ern Florida Everglades: Biogeochemistry, v. 40, p. 293-311.

Krabbenhoft, David P., Gilmour, Cynthia C., Benoit, Janina M., Babiarz, Christopher L., Andren, Anders W., and Hurley, James P., 1998, Methyl mercury dynamics in littoral sediments of a temperate seepage lake: Canadian Journal of Fisheries and Aquatic Sciences, v. 55 , no. 4 , p. 835-844. 
Krabbenhoft, David P., Hurley, James P., Olson, Mark L., and Cleckner, Lisa B., 1998, Diel variability of mercury phase and species distributions in the Florida Everglades: Biogeochemistry, v. 40, p. $311-325$.

Peters, C.A., and others, 1998, Water-quality in the western Lake Michigan drainages, Wisconsin and Michigan, 1992-95: U.S. Geological Survey Circular 1156, 40 p.

Robertson, D.M., Elder, J.F., Goddard, G.L., and James, W.F., 1998, Dynamics in phosphorus retention in wetlands upstream of Delavan Lake, Wisconsin: Lakes and Reservoir Management, v. 14, no. 4 , p. $466-477$.

Schindler, John E., and Krabbenhoft, David P., 1998, The hyporheic zone as a source of dissolved organic carbon and carbon gases to a temperate forested stream: Biogeochemistry, v. 43, p. 157-174.

Team for Evaluating the Wisconsin Water-Monitoring Network; 1998, An integrated water-monitoring network for Wisconsin: University of Wisconsin Water Resources Center Special Report WRC SR 98-01, $62 \mathrm{p}$.

Thorstenson, Donald C., Weeks, Edwin P., Haas, Herbert, Busenberg, Eurybiades, Plummer, L. Niel., and Peters, Charles A., 1998, Chemistry of unsaturated zone gases sampled in open boreholes at the crest of Yucca Mountain, Nevada: Data and basic concepts of chemical and physical processes in the mountain: Water Resources Research, v. 34 , no. 6, p. 1507-1529.

Walker, J.F., and Krabbenhoft, D.P., 1998, Groundwater and surfacewater interactions in riparian and lake-dominated systems in McDonnell, J.J., and Kendall, C., eds., Isotopic tracers in catchment hydrology: Elsevier, Amsterdam, The Netherlands, p. 467-486.

Fitzgerald, S.A., and Steuer, J.J., 1997, Polychlorinated biphenyls (PCBs) as probes of biogeochemical processes in rivers, in Molecular Markers in Environmental Geochemistry, Eganhouse, R.P., ed.: American Chemical Sociey Symposium Series, p. 382397.

Fitzgerald, S.A., and Steuer, J.J., 1997, Polychlorinated biphenyls (PCBs) as probes of biogeochemical processes in rivers, American Chemical Society Annual Meeting, Orlando, Florida, August 1996.

Hornewer, N.J., Johnson, G.P., Robertson, D.M., and Hondzo, M., 1997, Field-scale tests for determining mixing patterns associated with coarse-bubble air diffuser configurations, Egan Quarry, Illinois, in Environmental and Coastal Hydraulics: Protecting the Aquatic Habitat, proceedings of the International Association of Hydraulic Research, San Francisco, CA, USA, p. 57-63.

Hunt, R.J., Krabbenhoft, D.P., and Anderson, M.P., 1997, Assessing hydrogeochemical heterogeneity in natural and constructed wetlands: Biochemistry, v. 39 , p. $271-293$

Olson, M.L., Cleckner, LB., Hurley, J.P., Krabbenhoft, D.P., and Heelan, T.W., 1997, Resolution of matrix effects on analysis of total and methyl mercury in aqueous samples from the Florida Everglades: Fresenius Journal of Analytical Chemistry, v. 358, p. 392-396.

Robertson, D.M., 1997, Regionalized loads of sediment and phosphorus to Lakes Michigan and Superior - High flow and long-term average: Journal of Great Lakes Research, v. 23, p. 416-439.

Walker, J.F., and Wang, D., 1997, Measurement of flow under ice covers in North America: Journal of Hydraulic Engineering, v. 123, no. 11 , p. 1037-1040.
Anderson, W.L., Robertson, D.M., and Magnuson, J.J., 1996, Evidence of recent warming and El Nino-related variation in ice breakup of Wisconsin lakes: Limnology and Oceanography, v. 41, p. 815 821.

Bullen, T.D., Krabbenhoft, D.P., and Kendall, C., 1996, Kinetic and mineralogic controls on the evolution of groundwater chemistry and ${ }^{87} \mathrm{Sr} /{ }^{86} \mathrm{Sr}$ in a sandy silicate aquifer, northern Wisconsin: Geochemica Cosomchemica Acta, v. 60, p. 1807-1821.

Elder, J.F., James, R.V., and Steuer, J.J., 1996, Mobility of 2,2',5,5'tetrachlorobiphenyl in model systems containing bottom sediments and water from an industrialized river basin in northeastern Wisconsin: Journal of Great Lakes Research, v. 22, no. 3, p. 697 . 706.

Gebert, Warren A. and Krug, William R., 1996, Streamflow trends in Wisconsin's driftless area: Journal of the American Water Resources Association, v. 32, no. 4, p. 733-744.

Hunt, R.J., Krabbenhoft, D.P., and Anderson, M.P., 1996, Groundwater inflow measurements in wetland systems: Water Resources Research, v. 32, no. 3, p. 495-507.

Hunt, R.J., and Krohelski, J.T., 1996, The application of an analytic element model to investigate ground-water lake interactions at Pretty Lake, Wisconsin: Joumal of Lakes and Reservoir Management, v. 12 , no. 4 , p. $487-495$.

Imberger, J., Robertson, D.M., and Boland, K., 1996, Lake Number $A$ quantitative indicator of mixing to be used in water quality management: ScientificImpeller, Solna, Sweden, no. 4, p. 9-15.

Klump, J.V., Edgington, D.N., Sager, P.E., and Robertson, D.M., 1996, The bigeochemistry of Green Bay - 1. Sedimentary phosphorus cycling in a phosphorus mass balance for the Green Bay ecosystem: Canadian Journal of Fisheries and Aquatic Sciences, v. 54, no. 1, p. $10-26$.

Krug. William R., 1996, Simulation of temporal changes in rainfallrunoff characteristics, Coon Creek Basin, Wisconsin: Journal of the American Water Resources Association, v. 32, no. 4, p. 745752.

Assel, Raymond A., and Robertson, Dale M., 1995, Changes in winter air temperatures near Lake Michigan, 1851-1993, as determined from regional lake-ice records: limnology and Oceanography, $v$. 40 , no. I, January 1995, p. 165-176.

Assel, R.A., Robertson, D.M., Hoff, M.H., and Selgeby, J.H., 1995, Climatic-change implications from long-term (1823-1994) ice records near the Laurention Great Lakes: Annals of Glaciology, v. 21 , p. $383-386$

Greb, Steven R., and Graczyk, David J., 1995, Frequency duration analysis of dissolved-oxygen concentrations in two southwestern Wisconsin streams: Water Resources Bulletin, American Water Resources Association, v. 31, no. 3, June 1995, p. 431-438.

Kendall, C., and Krabbenhoft, D.P., 1995, Applications of isotopes to tracing sources of solutes and water in shallow systems in Charbeneau, R.J., ed., Groundwater Management, proceedings of the international symposium, August 1995, San Antonio, Tx, American Association of Civil Engineers, p. 390-395.

Krabbenhoft, David P., Benoit, Janina M., Babiarz, Christopher L., Hurley, James P., and Andren, Anders W., 1995, Mercury cycling in the Allequash Creek watershed, northern Wisconsin Water, Air, and Soil Pollution, v. 80, nos. 1/4, February 1995, p. 425-433.

Krabbenhoft, David P., and Webster, Katherine E., 1995, Transient hydrogeological controls on the chemistry of a seepage lake: Water Resources Research, v. 31, no. 9, September 1995, p. 2295-2305. 
Velleux, Mark, Endicott, Douglas, Steuer, Jeffrey, Jaeger, Steven, and Patterson, Dale, 1995, Long-term simulation of PCB export from the Fox River to Green Bay: Journal of Great Lakes Research, International Association for Great Lakes Research, v. 21, no. 3, 1995 , p. 359-372.

Wentz, Dennis A., Rose, William J., and Webster, Katherine E., 1995, Long-term hydrologic and biogeochemical responses of a soft water seepage lake in north central Wisconsin: Water Resources Research, v. 31, no. 1, January 1995, p. 199-212.

Elder, John F., 1994, Distribution and grain-size partitioning of metals in bottom sediments of an experimentally acidified Wisconsin lake: Water Resources Bulletin, v. 30, no. 2, p. 251-259.

Hurley, J.P., Krabbenhoft, D.P., Babiarz, C.L., and Andren, A.W., 1994, Cycling processes of mercury across sediment/water interfaces in seepage lakes in Baker, L.A., ed., Environmental Chemistry of Lakes and Reservoirs: Advances in Chemistry Series, American Chemical Society, Washington, D.C., p. 426-449.

Krabbenhoft, David P., Bowser, Carl J., Kendall, Carol, and Gat, Joel R., 1994, Use of oxygen-18 and deuterium to assess the hydrology of groundwater/lake systems in Baker, L.A., ed., Environmental Chemistry of Lakes and Reservoirs: Advances in Chemistry Series, American Chemical Society, Washington, D.C., p. 67-90.

Robertson, D.M., Anderson, W., and Magnuson, J.J., 1994, Relations between El Nino/Southern Oscillation events and the climate and ice cover of lakes in Wisconsin, p. 48-57. in Greenland, D. ed., El Nino and Long-Term Ecological Research (LTER) Sites, Publication no. 18, LTER Network Office: University of Washington, Seattle, WA, $57 \mathrm{p}$.

Robertson, D.M. and Imberger, J., 1994, Lake Number, a quantitative indicator of mixing used to estimate changes in dissolved oxygen. Internationale Revue der gesamten: Hydrobiologie, v. 79, p. $159-176$

Teal, M.J., Ettema, R., and Walker, J.F., 1994, Estimation of mean flow velocity in ice-covered channels: Journal of Hydraulic Engineering, v. 120 , no. 12 , p. 1385-1400.

Walker, John F., 1994, Methods for measuring discharge under ice cover: Journal of Hydraulic Engineering, v. 120, no. 11, p. 13271336.

Walker, John F., 1994, Statistical techniques for assessing water-quality effects of BMPs: Journal of Irrigation and Drainage Engineering, v. 120 , no. 2 , p. $334-347$.

Bannerman, R.T., Owens, D.W., Dodds, R.B., and Hornewer, N.J., 1993, Sources of pollutants in Wisconsin stormwater: Water Science Technology, v. 28, no. 3-5, p. 241-259.

Fitzgerald, S.A., and Gardner, W.S., 1993, An algal carbon budget for pelagic/benthic coupling in Lake Michigan: Limnology and Oceanography, v. 28, no. 3, p. 547-560.

Walker, John F., and Graczyk, David J., 1993, Preliminary evaluation of effects of best management practices in the Black Earth Creek, Wisconsin, priority watershed: Water Science Technology, v. 28, no. 3-5, p. 539-548.

Assel, R.A. and Robertson, D.M., 1992, Climatic changes near the Great Lakes inferred from 141-year ice records in proceedings of the 5th International Meeting on Statistical Climatology, Toronto, Canada, June, p. 81-85.

Krabbenhoft, D.P., Anderson, M.P., and Bowser, C.J., 1992, Reply to comment by Stauffer on "Estimating groundwater exchange with lakes using stable isotopes:" Water Resources Research, v. 28, no. 6, p. 1751-1753.
Krabbenhoft, D.P., and Babiarz, C.L., 1992, Role of groundwater transport in aquatic mercury cycling: Water Resources Research, v. 28 , no. 12 , p. $3119-3128$.

Luecke, C., Lunte, C.C., Wright, R.A., Robertson, D.M., and McLain, A.S., 1992, Impacts of variation in planktivorous fish on abundance of Daphnids: A simulation model of the Lake Mendota Food Web, in Kitchell, J.F. ed., Food Web Management - A Case Study of Lake Mendota: Springer-Verlag, New York, NY, 553 p.

Robertson, D.M., Ragotzkie, R.A., and Magnuson, J.J., 1992, Lake ice records used to detect historical and future climatic changes: Climatic Change, v. 21, p. 407-427.

Elder, J.F., and Collins, J.J., 1991, Freshwater molluscs as indicators of bioavailability and toxicity of metals in surface-water systems: Reviews of Environmental Contamination and Toxicology, v. 122 , no. 4 , p. $37-79$ :

Walker, J.F., 1991, Accuracy of selected techniques for estimating iceaffected streamflow: Journal of Hydraulic Engineering, v. 117, no. 6, p. 697-712.

Krabbenhoft, D.P., Anderson, M.P., and Boswer, C.J., 1990, Estimating groundwater exchange with lakes, 2 - Calibration of a threedimensional, solute transport model to a stable isotope plume: Water Resources Research, v. 26, no. 10, p. 2445-2462.

Krabbenhoft, D.P., Bowser, C.J., Anderson, M.P., and Valley, J.W., 1990, Estimating groundwater exchange with lakes, 1 - Use of the stable isotope method: Water Resources Research, v. 26, no. 10, p. $2445-2453$.

Lodge, D.M., Krabbehoft, D.P., and Striegl, R.G., 1989, Groundwater velocity and abundance of grazing of crayfish as predictors of submersed macrophyte biomass in Sparkling Lake, Wisconsin: Limnology and Oceanography, v. 34, no. 1, p. 235-239.

Walker, J.F., Pickard, S.A., and Sonzogni. W.C., 1989, Spreadsheet watershed modeling for nonpoint-source pollution management in a Wisconsin basin: Water Resources Bulletin, v. 25, no. 1, p. 139-147.

Wentz, D.A., Garrison, P.J., and Bockheim, J.G., 1989, Section 7Chemical input-output budgets, in Knauer, D., and Brouwer, S.A., eds., The Wisconsin Regional Integrated Lake-Watershed Acidification Study (RILWAS): 1981-1983: Palo Alto, California, Electric Power Research Institute Report EA-6214, p. 7-1 to 7-30.

Wentz, D.A., and Rose, W.J., 1989, Interrelationships among hydrologic-budget components of a northern Wisconsin seepage lake and implications for acid-deposition modeling: Archives of Environmental Contamination and Toxicology, v. 18, p. 147-155.

Wentz, D.A., Rose, W.J., and Krohelski, J.T., 1989, Section 5-Hydrologic component, in Knauer, D., and Brouwer, S.A., eds., The Wisconsin Regional Integrated Lake-Watershed Acidification Study (RILWAS): 1981-1983: Palo Alto, California, Electric Power Research Institute Report EA-6214, p. 5-1 to 5-77.

Rochelle, B.P., Church, M.R., Gebert, W.A., Graczyk, D.J., and Krug, W.R., 1988, Relationship between annual runoff and watershed area for the eastern United States: Water Resources Bulletin, v. 24 , no. 1 , February 1988 , p. $35-41$.

Walker, J.F., 1988, General two-point method for determining velocity in open channel: ASCE Journal of Hydraulic Engineering, v. 114, no. 7, p. 801-805.

Graczyk, D.J., 1980, Flood insurance study of Verona, Dane County, Wisconsin, 3 fig., 3 pls. 
Grant, R.S., and Graczyk, D.J., 1979, Flood insurance study of Hayward, Sawyer County, Wisconsin, $42 \mathrm{p}$.

Graczyk, D.J., 1978, Flood insurance study of Marathon City, Marathon County, Wisconsin, 1 fig., 3 pls.

Graczyk, D.J., 1978, Flood insurance study of Athens, Marathon County, Wisconsin, 3 figs., 3 pls. 


\section{WISCONSIN DISTRICT PERSONNEL}

DISTRICT OFFICE-MIDDLETON 53562

8505 Research Way

Phone: (608) 828-9901

FAX: (608) 821-3817

Office Hours: 0800 to 1630

\section{Office of the District Chief}

Gebert, Warren A., District Chief (608)821-3801 (wagebert@usgs.gov)

Elder, John F., Research Hydrol/Biol

(608) 821-3854

\section{Administrative Services Unit}

Grover, Richard L., Admin Off

(608) 821-3803 (rlgrover@usgs.gov)

Maertz, Diane E., Admin Opers Asst

(608) 821-3801

Fuller, Jan M., Admin Opers Asst

(608) 821-3802

Urben, Julie A., Admin Opers Asst

(608) 821-3804

Moore, Merry E., Admin Opers Asst

(608) $828-9901$ or 0

\section{Computer Applications Unit}

Bodoh, Robert B., Comp Prog Analyst

(608) 821-3805 (rbbodoh@usgs.gov)

Gill, Gary W., Comp Asst

(608) 821-3866

\section{Publications Unit}

Greenwood, Michelle M., Chief, Pub Unit (608) 821-3812 (mmgreenw@usgs.gov)

Jones, Susan Z., Edit Asst

(608) $821-3815$

\section{Environmental Studies Section}

Hughes, Peter E., Chief Supv Hydrol/Biol (608) 821-3833 (pehughes@usgs.gov)

Walker, John F., Research Hydrol/Engr (608) 821-3853

Graczyk, David J., Hydrol/For

(608) 821-3840

Hall, David W., Hydrol

(608) 821-3875

Krug, William R., Hydrol/Engr

(608) 821-3829

Steuer, Jeffrey J., Hydrol/Eng

(608) $821-3830$

Corsi, Steven R., Hydrol/Eng

(608) 821-3835

House, Harold R., Hydrol/Eng

(608) 821-3876

Owens, David W., Hydr Engr

(608) 821-3863

Stuntebeck, Todd D., Phys Sci

(608) 821-3872
Waschbusch, Robert J., Hydrol

(608) 821-3868

Booth, Nathaniel, Hydr Eng

(608) 821-3822

Selbig, Willaim, Hydrol

(608) 821-3823

Goddard, Gerald L., Hyd Tech

(608) 821-3841

Hanson, Halward L., Hyd Tech

(608) 821-3862

Housner, David E., Hyd Tech

(608) 827-6255, ext. 15

Rutter, Troy D., Hyd Tech

(608) 821-3848

Wierl, Judy A., Hydr Eng

(608) 821-3874

Hydrogeologic Studies and Data Section

Krohelski, James T., Chief Supv Hydrol

(608)821-3850 (jtkrohel@usgs.gov)

Krabbenhoft, David P., Research Hydrol/GeoChem

(608) 821-3843

Hunt, Randall J., Hydrol/Geol

(608) 821-3847

Feinstein, Daniel T., Hydrol

(414) 297-3172

Olson, Mark L., Biol

(608) 821-3878

Ellefson, Bernard R., Hyd Tech

(608) 821-3849

Dunning, Charles D., Physical Scientist

(608) 821-3827

Sabin, Ty, Physical Scientist

(608) 821-3873

DeWild, John F., Hyd Tech

(608) 821-3846

Rauman, James M., Hyd Tech

(608) 821-3871

Hydrologic Systems and Data Section

Garn, Herbert, Chief Supv Hydrol

(608)821-3828 (hsgarn@usgs.gov)

Rose, William J., Hydrol/Engr

(608) 821-3834

Holmstrom, Barry K., Hydrol/Engr

(608) 821-3831

Olson, Daniel L., Hyd Tech

(608) 821-3852

Homant, Paulette, Hyd Tech

(715) 356-9494

Stark, Patricia A., Hyd Data Asst

(608) 821-3838 
National Water Quality Assessment Program Peters, Charles A., Chief Supv Hydrol

(608) 821-3810 (capeters@usgs.gov)

Fitzgerald, Sharon A., Research Hydrol/Biol (813) 893-3100, ext. 3082

Robertson, Dale P., Research Hydrol/Chem (608) 821-3867

Fitzpatrick, Faith A., Hydrol

(608) 821-3818

Sullivan, Daniel J., Hydrol

(608) 821-3869

Scudder, Barbara C., Research Hydrol/Biol (608) 821-3832

Saad, David A., Hydrol/Geol

(608) 821-3865

Schmidt, Morgan, Hydrol

(608) 821-3820

Richards, Kevin E., Hyd Tech

(608) 821-3861

Stewart, Jana S., Geographer

(608) 821-3855
FIELD HEADQUARTERS-MIDDLETON 53562

8551 Research Way, Suite 120

Phone: (608) 827-6255

Office Hours: 0800 to 1630

Habale, Josef, Hyd Tech, ext. 10

Koenig, Kenneth R., Hyd Tech, ext. 13

March, Steven A., Hyd Tech, ext. 12

Wittwer, Thomas A., Hyd Tech, ext. 14

FIELD HEADQUARTERS-RICE LAKE 54868

313 W. Knapp St., P.O. Box 506

Phone: (715) 234-4015

Office Hours: 0800 to 1630

Popowski, Thomas J., Hyd Tech

Schuler, Josef G., Hyd Tech

Bernard Lenz, Hydraulic Engineer

FIELD HEADQUARTERS-MERRILL 54452

2011 East Main Street

Phone: (715) 536-2200

Office Hours: 0800 to 1630

Hanig, Jeffrey J., Hyd Tech

Esser, Brett M., Hyd Tech 


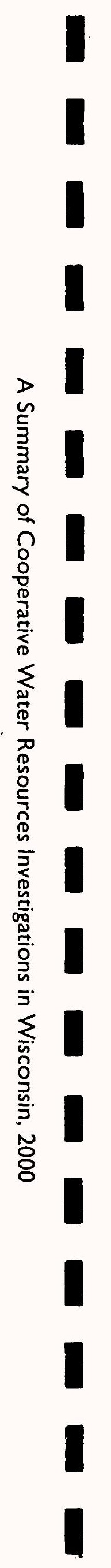

